\title{
QUATERNARY ACOUSTIC STRATIGRAPHY BETWEEN THE COLVILLE RIVER AND PRODHOE BAY, BEAUFORT SEA SHELF, ALASKA
}

\author{
by
}

David S. Foster ${ }^{1}$

Open-File Report 88-276

This report is preliminary and has not been reviewed for conformity with U.S. Geological Survey editorial standards and stratigraphic nomenclature. Any use of trade names is for descriptive purposes only and does not imply endorsement by the USGS.

${ }^{1}$ U.S. Geological Survey, Menlo Park, California 94025 
IST OF FIGURES

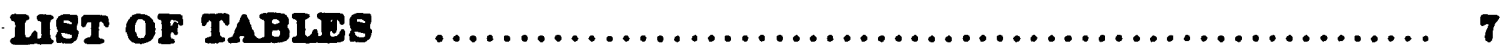

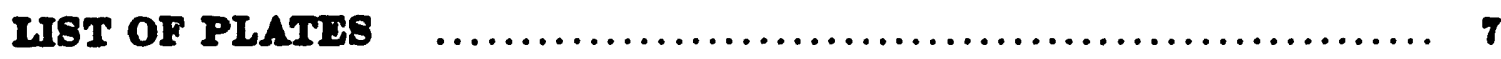

ACKNOWLEDGHMENTS $\ldots \ldots \ldots \ldots \ldots \ldots \ldots \ldots \ldots \ldots \ldots \ldots \ldots, \ldots$

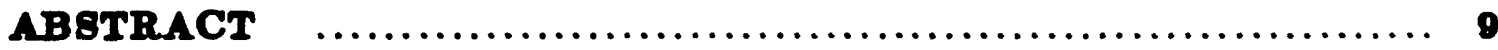

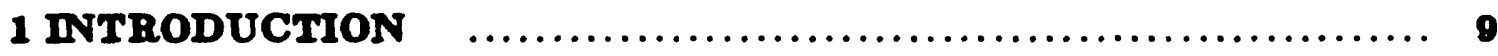

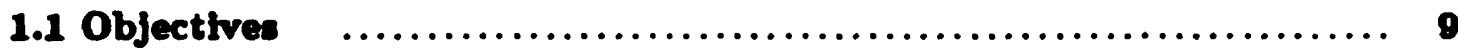

1.2 Geologic Betting $\quad \ldots \ldots \ldots \ldots \ldots \ldots \ldots \ldots \ldots \ldots \ldots \ldots \ldots \ldots \ldots \ldots, 11$

2 PREVIOU INVEgtigations $\ldots \ldots \ldots \ldots \ldots \ldots \ldots \ldots \ldots \ldots \ldots, 13$

2.1 Onshore Quaternary Btratigraphy $\quad \ldots \ldots \ldots \ldots \ldots \ldots \ldots \ldots \ldots \ldots, 13$

2.2 Offihore Quaternary Acountic 8tratigraphy $\ldots \ldots \ldots \ldots \ldots \ldots \ldots, 15$

2.3 Offohore Quaternary Borehole Btratigraphy $\quad \ldots \ldots \ldots \ldots \ldots \ldots \ldots .22$

2.4 Subsea Permafroat and Gab-bearing Bedments $\ldots \ldots \ldots \ldots \ldots \ldots .23$

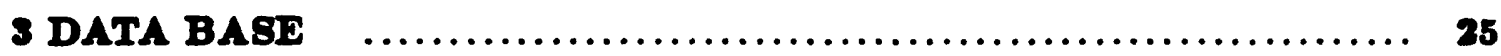

3.1 Figh-resolution Acoustic Reflection Data $\ldots \ldots \ldots \ldots \ldots \ldots \ldots \ldots .25$

3.2 Tracklline Dhatribution $\quad \ldots \ldots \ldots \ldots \ldots \ldots \ldots \ldots \ldots \ldots \ldots \ldots \ldots \ldots \ldots \ldots \ldots \ldots, 25$

3.3 Acoustic Data Quality $\quad \ldots \ldots \ldots \ldots \ldots \ldots \ldots \ldots \ldots \ldots \ldots \ldots \ldots, 27$

3.4 Borehole Data $\quad$......................................... 28

4 METHODS OF INTERPRETATION $\ldots \ldots \ldots \ldots \ldots \ldots \ldots \ldots \ldots \ldots \ldots \ldots \ldots$

8 RESULTS AND INTERPRETATION $\ldots \ldots \ldots \ldots \ldots \ldots \ldots \ldots \ldots$

8.1 Acountic 8tratigraphy $\ldots \ldots \ldots \ldots \ldots \ldots \ldots \ldots \ldots \ldots \ldots \ldots, 29$

Acountic Bequence $\mathbf{E} \quad \ldots \ldots \ldots \ldots \ldots \ldots \ldots \ldots \ldots \ldots \ldots \ldots \ldots, \quad 31$

Acoustic Bequence D $\ldots \ldots \ldots \ldots \ldots \ldots \ldots \ldots \ldots \ldots \ldots \ldots \ldots, \quad 36$

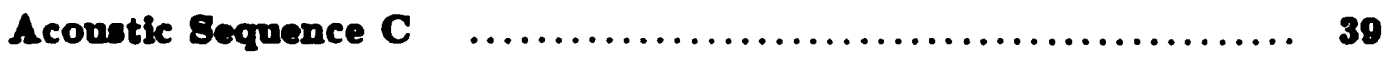


TABLE OF CONTENTS (continued)

PAGE

Acoustic Sequence B

41

Acoustic Sequence $\mathbf{A}$ 47

Acoustic Sequence A/B

Relationships of Acoustic Stratigraphy to Shoals $\ldots \ldots \ldots \ldots \ldots \ldots, \mathbf{5 2}$

$5.2{ }^{14} \mathrm{C}$ Analysis 53

5.3 Subsea Permafrost and Gas-bearing Sediments 55

5.4 Summary of Results $\mathbf{5 5}$

6 DISCUSSION $\mathbf{5 7}$

6.1 Correlation of Acoustic Stratigraphy

6.2 Correlation of Acoustic Stratigraphy to Offshore Borehole

Stratigraphy 63

6.3 Correlation of Acoustic Stratigraphy to Onshore Stratigraphy $\quad \ldots \quad 65$

6.4 Chronostratigraphy 65

6.5 Sea-level History 68

6.6 Synthesis of Quaternary Depositional History 71

7 CONCLUSION AND RECOMMENDATIONS 72

8 REFERENCES

9 APPENDIX 1. PRINCIPLES OF HIGH-RESOLUTION ACOUSTIC REFLECTION PROFHING

10 APPENDIX 2. AVAILABILITY OF ACOUSTIC PROFILES $\ldots \ldots \quad 89$

11 APPENDIX 3. BOREHOLE CORRELATIONS $\ldots \ldots \ldots \ldots \ldots \ldots \ldots$ 


\section{LIST OF FIGURES}

PAGE

Figure 1-1. The study area between the Colville River and Prudhoe Bay $\ldots \ldots \ldots 10$

Figure 1-2. Bathymetry contoured at a $5 \mathrm{~m}$ interval (modified from Rearic et al., 1981)

Figure 2-1. Map of Late Cenozoic deposits of the Arctic Coastal Plain (after Rawlinson, 1986)

Figure 2-2. Tentative Holocene marine sediment isopach map for sediments above horizon A (after Reimnitz et al., 1972)

Figure 2-3. Structure contour of surface 4 (after Wolf et al., 1985)

Figure 2-4. Structure contour of surface 3 (after Wolf et al., 1985)

Figure 2-5. Isopach map of Holocene sediments between Surface 5? and the sea-floor (after Wolf et al., 1985)

Figure 3-1. Trackline map for high-resolution acoustic profiles and plotted borehole locations

Figure 5-1. Generalized stratigraphic column showing the order of acoustic sequences and sequence boundaries

Figure 5-2. Location map of boreholes that were correlated to acoustic profiles, cross-sections, and figures

Figure 5-3. Structure contour map of R20 and R20(?) and the distribution of the surface of Sequence E.

Figure 5-4. Boomer profile (Line 15-75) showing a cut and fill channel with a prograding channel fill deposit

Figure 5-5. Structure contours on the top of Acoustic Sequence E. Depth to Sequence $\mathbf{E}$ and sediment overburden above Sequence $\mathbf{E}$

Figure 5-6. Structure contour map of the upper boundaries (R30 and R30=R40) of Sequence $\mathrm{D}$ and the distribution of R30(?)

Figure 5-7. Structure contour map of the upper boundary (R40) of Sequence $C$ and the distribution of R40(?)

Figure 5-8. The distribution of Sequence B features 


\section{LIST OF FIGURES (continued)}

PAGE

Figure 5-9a. Example of a sharp Acoustic Transmission Boundary (ATB) from a boomer profile (Line 22-80)

Figure 5-9b. Example of a transitional Acoustic Transmission Boundary (ATB) showing a "jumpy" appearance from a boomer profile (Line 59-80)

Figure 5-10. Boomer profile (Line 59-80) showing a symmetrical cut and fill channel that was interpreted to be a buried distributary channel $\ldots \ldots \ldots 45$

Figure 5-11. Progradational delta sequence on a boomer profile (Line 59-80) $\quad . \quad 46$

Figure 5-12. Isopach map of Sequence $A$ and structure contours of the lower boundary (R45) of Sequence $A / B \quad \ldots \ldots \ldots \ldots \ldots \ldots \ldots \ldots$

Figure 5-13. Boomer profile (Line 35-83) with a "pitted" character that resulted from a discontinuous R50

Figure 5-14a. Boomer profile (Line 14-75) with a chaotic reflector configuration truncating R50

Figure 5-14b. Boomer profile (Line 71-77) with a disrupted R50 seaward of Stamukhi Shoal

Figure 5-15. The stratigraphic position of a ${ }^{14} \mathrm{C}$ dated detrital peat superimposed on to interpretive line drawings of two boomer profiles

Figure 5-16. Boomer profile (Line 751-77) from the middle shelf showing the inferred gas-enhanced R30, reflector pulldown, and attenuated zones . 56

Figure 6-1. Locations of transects and ${ }^{14} \mathrm{C}$ dated sediments $\ldots \ldots \ldots \ldots \ldots$

Figure 6-2. Borehole transect from ARCO West Dock to Reindeer Island (after Hartz and Hopkins, 1980)

Figure 6-3. Correlation of Sequence E to Ugnuravik gravel on the coastal plain 66

Figure 6-4. Beringian sea-level curve (modified from Hopkins, 1982) $\ldots \ldots \ldots 69$

Figure 9-1. The basic components of continuous acoustic profiling (after Sylwester, 1983)

Figure 9-2. The relationship of acoustic source frequency to depth penetration, vertical resolution (after Sylwester, 1983) 


\section{LIST OF FIGURES (continued)}

PAGE

Figure 9-3. Ray path of two-way travel time (TWT) from source to receiver

Figure 9-4. Graphic recorder showing vertical and horizontal scales on the chart paper, sweep rate, and example reflector

Figure 11-1. Borehole BE-13 correlated with a boomer profile (Line 17-72) $\ldots 99$

Figure 11-2. Borehole BE-13 correlated with a boomer profile (Line 15-75) $\ldots 92$

Figure 11-3. Borehole BE-14 correlated with a boomer profile (Line 17-72) $\ldots 93$

Figure 11-4. Borehole BE-14 correlated with a boomer profile (Line 15-75) _.. 94

Figure 11-5. Borehole EBA-1 correlated to a boomer profile (Line 22-80) and a $3.5 \mathrm{kHz}$ profile (Line 144)

Figure 11-6. Borehole EBA-2 correlated with a boomer profile (Line 28-80) $\ldots \quad 96$

Figure 11-7. Borehole EBA-7 correlated with a $3.5 \mathrm{kHz}$ profile (Line 150) $\ldots .97$

Figure 11-8. Borehole EBA-8 correlated with a boomer profile (Line 18-72) $\ldots 98$

Figure 11-9. Borehole EBA-8 correlated with a $3.5 \mathrm{kHz}$ profile (Line 146) $\ldots .99$

Figure 11-10. Borehole EBA-11 correlated with a $3.5 \mathrm{kHz}$ profile (Line 140) $\quad . \quad 100$

Figure 11-11. Borehole EBA-23 correlated with a boomer profile (Line 20-72) · 101

Figure 11-12. Borehole EBA-23 correlated with a boomer profile (Line 13-75) . 102

Figure 11-13. Borehole EBA-24 correlated with a boomer profile (Line 17-72) . 103

Figure 11-14. Borehole EBA-24 correlated with a boomer profile (Line 13-75) . 104

Figure 11-15. Borehole HLA-3 correlated with a boomer profile (Line 21-72) .. 105

Figure 11-16. Borehole HLA-4 correlated with a boomer profile (Line 84-79) $\quad . \quad 106$

Figure 11-17. Borehole HLA-5 correlated with a boomer profile (Line 13-72) .. 107

Figure 11-18. Borehole PB-2 correlated with a boomer profile (Line 84-79) $\ldots 108$ 


\section{LIST OF TABLES}

PAGE

Table 2-1. Marine transgressions of the Harrison Bay Quadrangle (after

Carter and Galloway, 1985)

Table 6-1. Correlation of stratigraphic units on the Beaufort shelf and the Arctic Coastal Plain

Table 6-2. Correlation of Quaternary deposits of the Arctic Coastal Plain and the Beaufort Sea shelf

Plate 1. Geologic Cross-section A

Plate 2. Geologic Cross-sections B and C

Plate 3. Geologic Cross-sections D and E 


\section{ACKNOWLEDGMENTS}

This report is derived from my graduate studies at the University of Alaska. The research was done as partial fulfillment of a M.S. degree in Oceanography in the Graduate Program of Marine Science and Limnology.

I convey my since appreciation to Dr. A. Sathy Naidu for providing the opportunity to attend graduate school and for chairing my advisory committee. I thank him for giving me guidance during my studics. I am grateful for the advice and support that committee members Dr. Peter W. Barnes, Dr. David M. Hopkins, Dr. John J. Kelley, and Dr. H. Joseph Niebauer provided. Additional acknowledgment is due to Dr. Peter W. Bames, Dr. Erk Reimnitz, and Edward W. Kempema of the U.S. Geological Survey, Branch of Pacific Marine Geology, for providing much of the data used in this study, for funding my travel to the U.S. Geological Survey office in Palo Alto, and for sharing their knowledge on Arctic marine geology. I have benefited from discussions with Stewart E. Rawlinson (Alaska State Geological and Geophysical Survey), Arthur Grantz (U.S. Geological Survey), Steve M. Blasco (Geological Survey of Canada), and David A. Vralsted (Standard Oil Production Company). I thank Peter P. Johnson (Minerals Management Service) for sharing his insight, and the Minerals Management Service for providing access to their data. Also, I appreciate Lawrence J. Toimil (HardingLawson Associates) for providing and giving consent to ${ }^{14} \mathrm{C}$ date their borehole samples. I thank my office partner, Shinn-Pyng Yeh, for providing assistance with the computer.

I am grateful to the following individuals and agencies for providing financial assistance during my studics: Dr. A. Sathy Naidu and the National Oceanic and Atmospheric Administration, Ocean Assessment Division (Grant no. NA-86-AHB-00013), Dr. John J. Kelley and Department of Energy, Office of Health and Environmental Research, Ecological Research Division (Grant no. DE-6FO6-84ER60269), and James Barker (U.S. Bureau of Mines, Fairbanks, Alaska). 


\begin{abstract}
At least five depositional sequences of the Quaternary Gubik Formation are defined acoustically on the Beaufort Sea shelf between the Colville River and Prudhoe Bay. Continuous reflectors on high-resolution acoustic profiles define sequence boundaries and are verified with borehole stratigraphy. Seaward dipping transgressive sequences onlap a fluvial sequence of probable Early Pleistocene age on the inner shelf. Holocene marine sediments are thin to absent on the inner shelf. Ice-bearing subsea permafrost enhances reflectors or produces reflectors unrelated to geologic contacts. The distribution of relict subsea permafrost is integrated into the depositional history of the offshore Gubik Formation. Bright and attenuated reflectors are assumed to originate from gas-bearing sediments. Tentative ages of acoustic sequences are derived from correlations to previous studies. Age-depth relations are compared to a local (Beringian) sea-level curve. Glacioeustatic sea-levels appear to have been the primary influence on Quaternary deposition. Sea-ice erosion may limit Holocene marine deposition.
\end{abstract}

\title{
1 INTRODUCTION
}

\subsection{Objectives}

A primary objective of the Quaternary geologist is to relate the geologic framework of a region to global patterns of glacio-eustatic sea-level changes. To accomplish this task, the stratigraphy of continental shelves and coastal plains is studied to identify transgressive and regressive sedimentary sequences. Correlations to global Quaternary history can be made provided the chronology and depositional history of the region are well understood.

Knowledge of the shallow subsurface geology has important economic value in the development of offshore resources. Continued development of petroleum resources on the Beaufort Sea shelf, including the construction of offshore structures, requires knowledge of the substrate and subsurface geology. Identifying geologic hazards is important in the safe development of the region. Two important hazards on the Beaufort Sea shelf are subsea permafrost and gas-bearing sediment. This study provides knowledge of a depositional history that may improve the understanding of subsea permafrost distribution. Also, the knowledge of offshore gravel resources may be improved.

The intent of this report is to define the shallow ( $<100 \mathrm{~m}$ thick) geologic framework and Quaternary geologic history of the Beaufort Sea shelf between the Colville River and Prudhoe Bay, Alaska (Figure 1-1). Observations are correlated to the results of previous investigations done on the perimeter of the study area. Correlations to previous acoustic reflection surveys improves the regional understanding of the Quaternary stratigraphy.

To accomplish the objectives of this report the stratigraphy is interpreted primarily from high-resolution acoustic reflection profiles. Appendix 1 reviews the basic principles of acoustic reflection profiling. High-resolution acoustic reflection data were acquired from several different surveys done with a variety of acoustic energy sources. Boomer type sources provide the acoustic energy for most of the data in this study (P.W. Barnes and E. Reimnitz, unpublished data; U.S. Geological Survey, 1980; Grantz and Greenburg, 1981). Additional data consist of $3.5 \mathrm{kHz}$ profiles (U.S. Geological Survey, 1980) and some $7 \mathrm{kHz}$ data (P.W. Barnes and E. Reimnitz, unpublished data). The acoustic stratigraphy is correlated with borehole data. ${ }^{14} \mathrm{C}$ dates of borehole samples provide some insight to the chronostratigraphy of acoustic reflectors and sequences. 


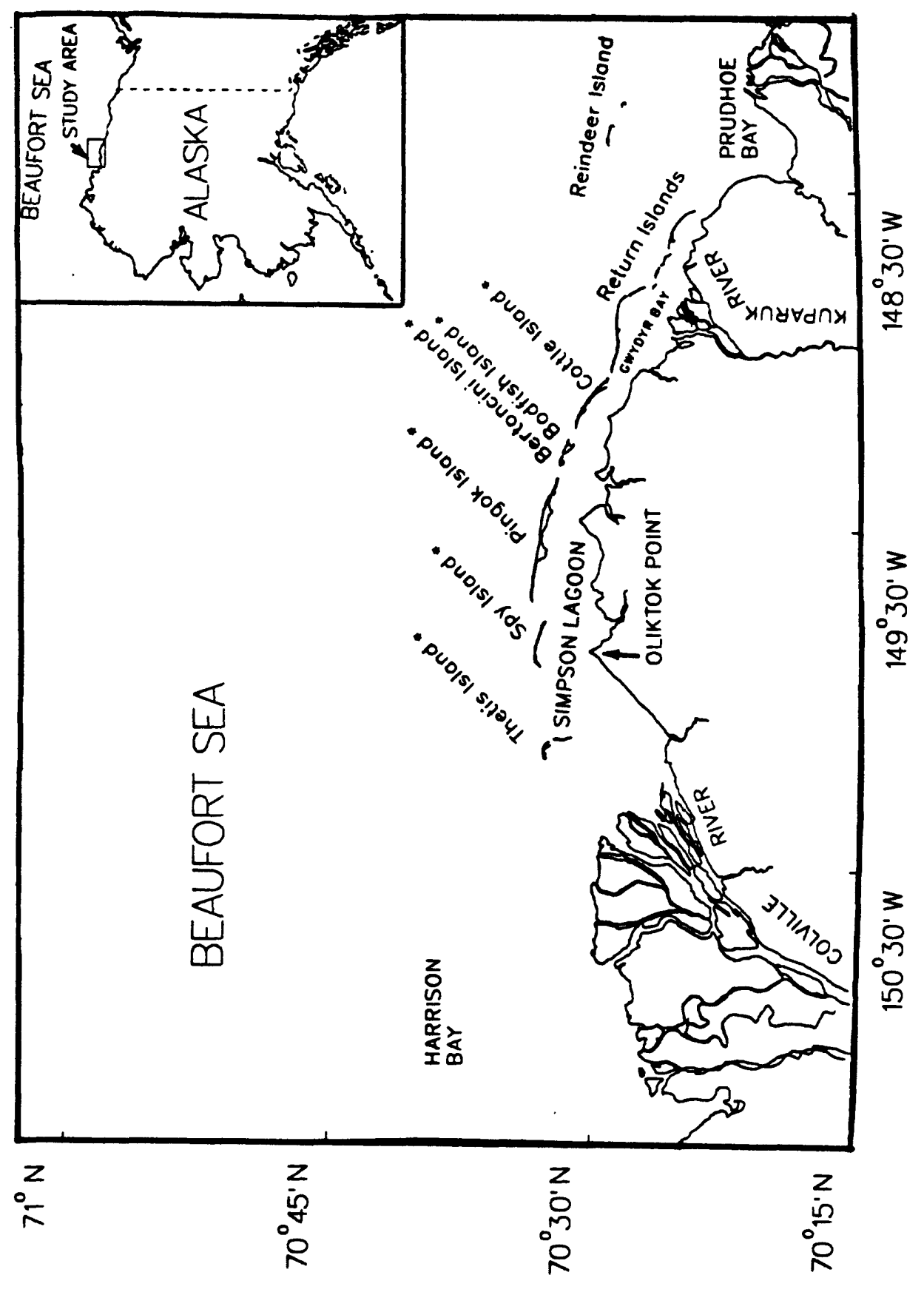

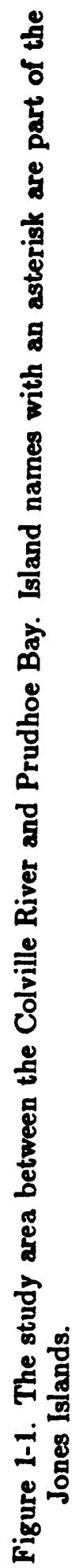




\subsection{Geologic Setting}

The Quaternary deposits of the Arctic Coastal Plain adjacent to the study area (Figure 1-1) consist of the Gubik Formation. Three terraces consisting of marine, alluvial, and fluvial deposits are part of the Gubik Formation in the vicinity of the Colville River Delta (Carter and Galloway, 1982). Several coalescing alluvial and glaciofluvial fans that have sources in the Brooks Range characterize the subsurface east of the Colville River (Hopkins and Hartz, 1978a). Eoloian sands on the coastal plain are from several depositional intervals of the Pleistocene and Holocene (Carter and Galloway, 1985). Eolian deposition was significant on the coastal plain until about 8,000 years B.P. when sands were stabilized by tundra vegetation (Carter et al., 1984). Pleistocene and Holocene thaw lake deposits and tundra mantle the coastal plain except where active and abandoned river channels cut across the surface.

The Beaufort Sea coast is irregular, deeply embayed in some areas, and has beaches, barrier islands, and low bluffs (about $3 \mathrm{~m}$ ) (Hopkins and Hartz, 1978a). The coastal fringes of the Colville and Kuparuk Deltas consist of mud flats. The coast retreats at an average rate of $2.1 \mathrm{~m} / \mathrm{yr}$ due to thermal and storm erosion, except the Colville Delta which progrades at an average rate of $0.4 \mathrm{~m} / \mathrm{yr}$ (Reimnitz et al., 1985). Barrier island chains extend from the mainland coast along with associated back barrier lagoons. The island chains originate west of major river mouths. A net westward littoral drift of the fluvial sediment load may provide sediment nourishment to the barrier islands (A.S. Naidu, personal communication, 1987). The Return and Jones Islands extend west from the Prudhoe Bay to the Colville Delta and separate Simpson Lagoon and Gwydyr Bay from the open Beaufort Sea. Except for the Eskimo Islands in western Harrison Bay, a barrier island chain is absent west of Thetis Island. Hopkins and Hartz (1978a) suggested that the Eskimo Islands are part of a Sangamon Stage strandline. They extended the shoreline east to the Jones Islands. Some of the Jones Islands (Pingok, Bodfish, Bertoncini, and Cottle Islands) are Pleistocene coastal plain remnants. Thetis and Spy Islands appear to be constructional from the Holocene transgression. While they appear to be constructional, they are actually well reworked coastal plain remnants (Hopkins and Hartz, 1978a). Also within the study area, Reindeer Island is at the end of a barrier island chain that extends from the east.

Figure 1-2 illustrates the bathymetry of the study area. Seaward of the barrier islands and shallow lagoons, the Beaufort shelf is about $75 \mathrm{~km}$ wide to the shelf break $(60 \mathrm{~m}$ isobath) and dips seaward at an average of $0.9 \mathrm{~m} / \mathrm{km}$ or a gradient of $1: 900$. The relatively narrow shelf and shallow shelf break suggest a regional uplift of the continental shelf (Reimnitz and Barnes, 1974). Some important bathymetric features include the $2 \mathrm{~m}$ bench (Barnes and Reimnitz, 1973), $18 \mathrm{~m}$ bench (Reimnitz and Barnes, 1974; Reimnitz et al., 1978; Barnes et al., 1987), and shoals associated with the stamukhi zone (Reimnitz and Maurer, 1978; Reimnitz and Kempema, 1984). Sea-ice covers the shelf up to 9 months of the year. Bathymetric features relate to sea-ice zonation and the interaction of sea-ice with hydraulic sedimentary processes (Reimnitz et al., 1978). The shelf is generally flat until there is a break in slope at the $2 \mathrm{~m}$ isobath $(2 \mathrm{~m}$ bench). The area landward of the $2 \mathrm{~m}$ isobath can be $10 \mathrm{~km}$ wide in Harrison Bay or as narrow as $0.5 \mathrm{~km}$ wide in other areas. The $2 \mathrm{~m}$ bench roughly corresponds to the maximum thickness of the seasonal fast ice; therefore, sea-ice may freeze the sea-floor at depths shallower than $2 \mathrm{~m}$ (Reimnitz and Barnes, 1974). The $2 \mathrm{~m}$ bench is also an important feature in relation to the breakup processes of Arctic rivers (Reimnitz and Bruder, 1972). A shear zone between relatively stable fast ice and the mobile pack ice defines the stamukhi zone (Zubov, 1945; Reimnitz et al., 1978). A belt of grounded ice ridges generally occur between the 18 and $25 \mathrm{~m}$ 


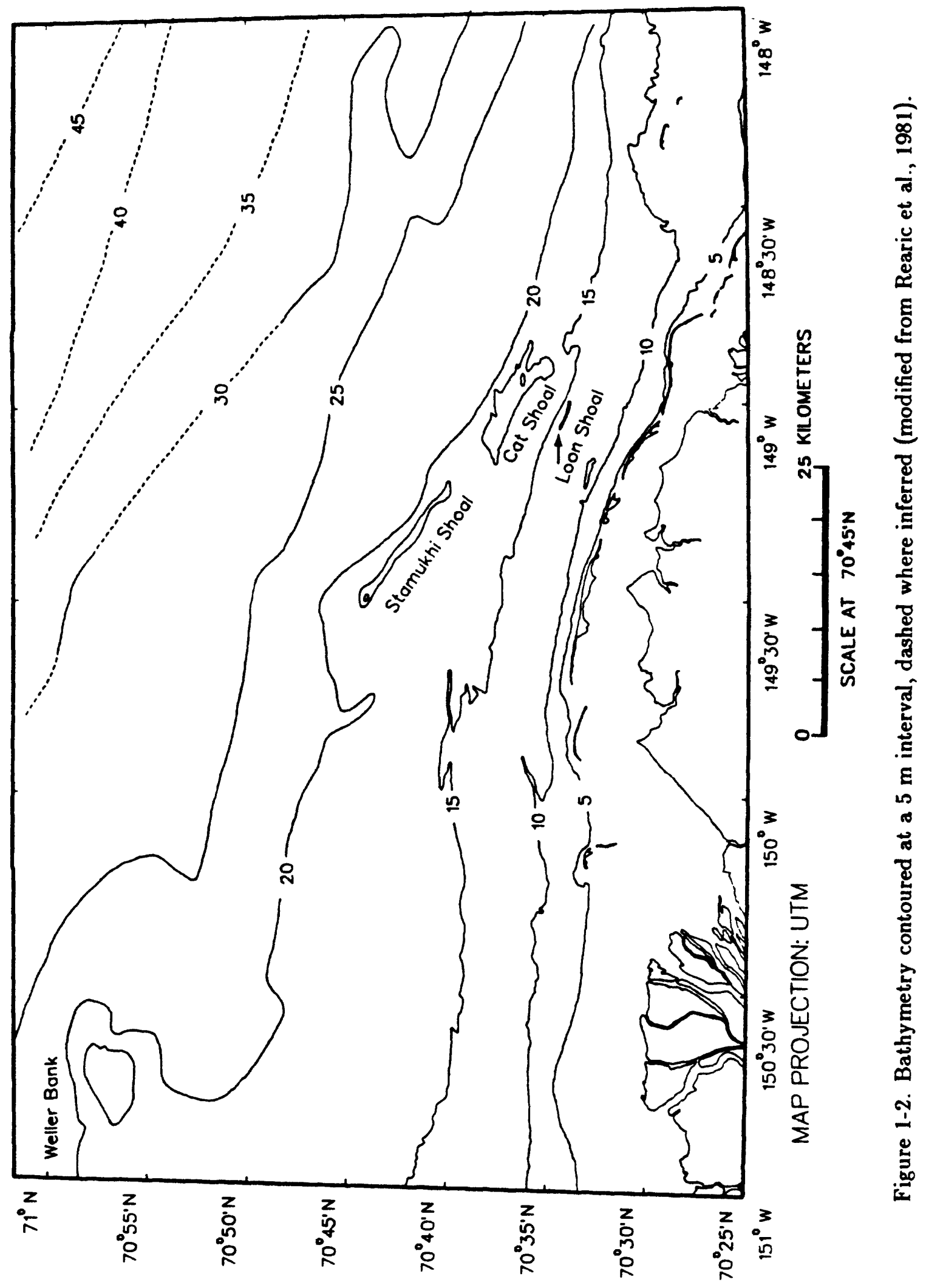


isobaths (Kovacs, 1976; Stringer, 1978). Shoals that rise up to $10 \mathrm{~m}$ above the seafloor dominate the inner shelf between the 10 and $30 \mathrm{~m}$ isobaths. Most often the larger shoals form at the inner edge of the stamukhi zone near the $20 \mathrm{~m}$ isobath (Reimnitz and Kempema, 1984). Reimnitz and Kempema (1984) suggested that these shoals are constructed by interaction of sea-ice and currents. Also, the inner edge of the stamukhi zone relates to a break in geologic character and morphology, called the $18 \mathrm{~m}$ bench or ice erosion knickpoint (Reimnitz and Barnes, 1974; Barnes et al., 1981; 1987). Abrasion, from intense ice gouging, seaward of the inner edge of the stamukhi zone forms this knickpoint (Barnes et al., 1987).

\section{PREVIOUS INVESTIGATIONS}

Several shallow stratigraphic studies from the Beaufort Sea shelf and the adjacent Arctic Coastal Plain Province are relevant to this report. On the shelf, most of the information of the stratigraphy comes from acoustic reflection surveys. These surveys delineate geological hazards and the engineering characteristics of the subsurface sediments. The acoustic reflection profiles provide information that enables construction of stratigraphic frameworks and depositional histories for the Beaufort shelf (Reimnitz et al., 1972; Craig and Thrasher, 1982; Dinter, 1982; 1985; Wolf et al., 1985).

\subsection{Onshore Quaternary Stratigraphy}

The Gubik Formation of Late Pliocene and Pleistocene age consists of Quaternary unconsolidated marine and nonmarine sediments that overlie Cretaceous or Tertiary rock (Payne et al., 1952; Black, 1964). Onshore investigations indicate a preserved record of marine transgressive sediments that interbed nonmarine deposits. A brief summary of the onshore Quaternary geology follows.

Early exploration of the North Slope stratigraphy by Schrader (1904) introduced the name Gubik Sands of Pleistocene age. Later, the same deposits are named the Gubik Formation (Payne et al., 1952). Black (1964) discussed three units of the Gubik Formation that essentially represent three sedimentary facies. McCulloch (1967) revised the stratigraphy to include at least six transgressive units that interbed alluvial, fluvial, eolian, and lake deposits. Brigham (1985) recognized six members within the Gubik Formation based on stratigraphy and aminostratigraphic dating. She constructed a stratigraphic framework with a basal transgressive sequence and overlying marine deposit for each member of the Gubik Formation. Carter and Galloway (1985) and Carter et al. (1986) correlated Brigham's (1985) members to transgressions on the Arctic Coastal Plain between Barrow and Prudhoe Bay. Table 2-1 shows the Late Cenozoic marine transgressions for the Harrison Bay Quadrangle (Carter and Galloway, 1985), an area bounded by longitudes $150^{\circ}$ and $153^{\circ}$ West and latitudes $70^{\circ}$ and $71^{\circ}$ North. Rawlinson (1986) indicated the stratigraphy east of the Colville River to the Canning River consists of fluvial, glaciofluvial, eolian, and lacustrine deposits. Marine deposits are absent with the exception of the Flaxman Member. He defined and mapped several stratigraphic units and provided ages for some deposits (Figure 2-1). Rawlinson (1986) was unable to extend the three marine cut terraces (Carter and Galloway, 1982) and the three or more transgressive units of the Gubik Formation of the Harrison Bay Quadrangle (Carter and Galloway, 1985) to deposits east of the Colville River. Based on this observation, he proposed three alternative explanations for the stratigraphy east of the Colville River. The alternatives are that 1) fluvial deposits exoded and eventually excavated the terraces, 2) marine terraces are not deposited where fluvial deposits exist, and 3) marine terrace deposits underlie fluvial deposits. Undocumented reports of shells in the base of a gravel pit support the third 
Table 2-1. Marine transgressions of the Harrison Bay Quadrangle and correlation of transgressions on the Arctic Coastal Plain (after Carter and Galloway, 1985).

\begin{tabular}{|c|c|c|c|c|c|}
\hline \multirow[b]{2}{*}{ Irensgression } & \multirow[b]{2}{*}{$\begin{array}{l}\text { Maximim } \\
\text { Elevation } \\
\text { Reached (m) }\end{array}$} & \multicolumn{4}{|c|}{ Alle/lle' } \\
\hline & & Ane & $\begin{array}{c}\text { Colvillie River } \\
\text { fish Creek } \\
\text { Ares }\end{array}$ & $\begin{array}{l}\text { Chutchi Seg } \\
\text { Coast Area }\end{array}$ & $\begin{array}{l}\text { Tent at ive Correlat ton } \\
\text { with Hopk ins }(1967)\end{array}$ \\
\hline stupsonien & 7 & $70 K_{0}$ to $80 K_{0}$ & $\ldots$ & $\ldots \ldots$ & (......... \\
\hline Pelutian & 10 & $120 \mathrm{~K}=$ to $130 \mathrm{~K}=$ & ............... & $.014 \pm .002$ & Peluk ion \\
\hline Hoinmerightien? & 20 & $>158 \mathrm{Ka}$ & $\ldots \ldots \ldots$ & $.038 \pm .007$ & ............ \\
\hline fishcreek ian & 25 & $1.87 \mathrm{Mo}_{0} 2.48 \mathrm{Mo}$ & $.006+.004(6)^{3}$ & $.090 \div .018$ & (n........... \\
\hline - igbendien & $>35,<60$ &, $2.48 \mathrm{Ma}$ & $.136+.014(12)^{3}$ & $.150 \pm .025$ & Anvilitan \\
\hline Colvilitian & $>40,<60$ & $<3.5 \mathrm{Mo}$ & $.236 \pm .022(8)^{3}$ & $.235 \pm .017$ & Ber ingian \\
\hline
\end{tabular}

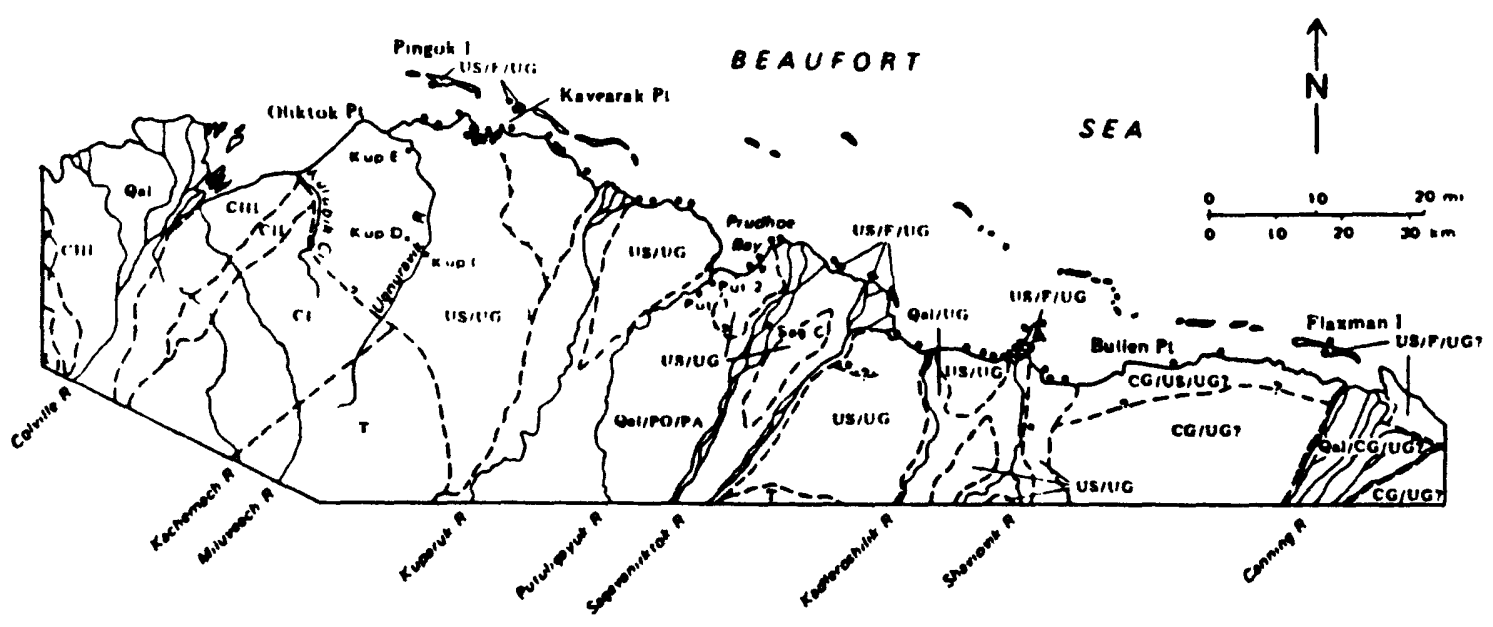

EXPLANATION
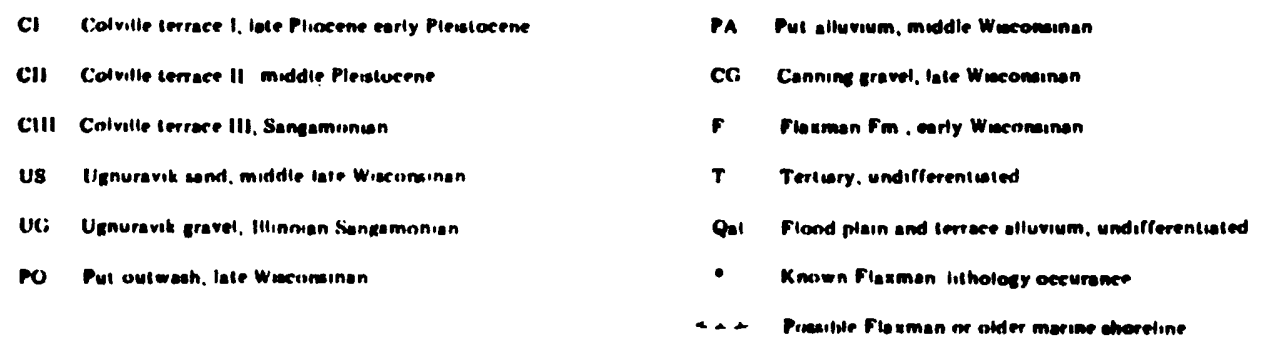

Figure 2-1. Map of Late Cenozoic deposits of the Arctic Coastal Plain. Map boundaries are dashed and stratigraphy is shown in descending order, separated by a slash. Units are queried where uncertain. Gravel pit locations are shown with a dot. (after Rawlinson, 1986). 
possibility.

Leffingwell (1919) named the youngest pre-Holocene transgressive deposit on the coastal plain the Flaxman. He described the lithology as a glacial till containing clasts that are foreign to Alaska. The Flaxman Formation is now considered to be a member of the Gubik Formation (Dinter, 1985). Also, the Flaxman Member lithology is more accurately described as a glacial marine diamicton (D.M. Hopkins, personal communication, 1987). The Flaxman Member is found below altitudes of $7 \mathrm{~m}$ and is a few meters thick (McCarthy, 1958; Hopkins, 1982). Transport by ice-rafting of the erratics, clasts that range from pebble to boulder size, of the Flaxman Member originate from a source in the Canadian Arctic (McCarthy, 1958; Naidu and Mowatt, 1974; Barnes and Reimnitz, 1974; Mowatt and Naidu, 1974; Rodeick, 1979). Implications of sediment transport and deposition of ice-rafted clasts may be important when considering transgressive depositional sequences on the Beaufort Sea shelf.

Hopkins and Hartz (1978a) summarized the geology of the Alaskan Arctic Coastal Plain. West of Oliktok Point, a Pelukian (Sangamon Stage) strandline ridge divides the coastal plain into inner and outer sections. Beneath the inner region, south of the Pelukian ridge, the Gubik Formation consists of Pleistocene marine pebble sands, Pleistocene eolian dune fields, and Pleistocene and Holocene sandy alluvial plains and deltas. (Williams et al., 1977; Carter and Robinson, 1978). The outer coastal plain, north of the Pelukian ridge, is underlain primarily by the compact pebbly marine silt of the Flaxman Member. East of Oliktok Point there is a marked increase in gravel content within the Gubik Formation. The increase in grain size is attributed to a series of coalescing alluvial and glacial outwash fans that underlie the coastal plain. The fans originate from the Brooks Range and extend to the Beaufort Sea coast where they overlap near coastal embayments such as Prudhoe Bay. The fan convergences are interpreted as paleovalleys that were excavated during sea-level lowstands (Hopkins et al., 1979). The Flaxman Member usually is deposited on promontories between paleovalleys of the coast, thus suggesting the Flaxman Member was removed during the incision of the valleys (D.M. Hopkins, personal communication, 1987).

A regional grain size trend within the Gubik Formation demonstrates that sand and gravel are more common east of the Colville River, and muds and silty sands extend to the west (see Briggs, 1983). Shallow borehole logs that penetrate the Gubik Formation south of Harrison Bay (Mead and Brockett, 1982) confirm increasing grain size to the east.

Investigations of the Arctic Coastal Plain Province indicate a fairly well preserved record of transgressive marine deposits that interbed non-marine alluvial, fluvial, eolian, and lacustrine sediments. Onshore studies provide an understanding of Quaternary sealevel highstands, whereas the offshore must be investigated to determine the position of sea-level lowstands and transgressions that have peaked below the present sea-level (Dinter, 1985).

\subsection{Offshore Quaternary Acoustic Stratigraphy}

Investigations using high-resolution acoustic reflection methods extend the Gubik Formation to the Beaufort Sea shelf (Reimnitz et al., 1972; Barnes et al., 1977; Reimnitz et al., 1977; Craig and Thrasher, 1982; Dinter, 1982 and 1985; Wolf et al., 1985).

Reimnitz et al. (1972) identified three acoustic sequences in and just seaward of Simpson Lagoon. The inferred Pleistocene sequence, between horizons A and B, unconformably overlies the Tertiary Sagavanirktok Formation. They extrapolated the ages from the stratigraphy of Howitt (1971) by tying structure contours of horizon B to onshore boreholes. Correlation of the acoustic sections with the boreholes assumed a relatively high 
sound velocity of $4500 \mathrm{~m} / \mathrm{s}$. This may be ressonable, since acoustic vélocities at 4500 $\mathrm{m} / \mathrm{s}$ in ice-bonded gravel are possible (Roethlisberger, 1972). Reimnitz et al. (1972) also contended that a reflector (horizon $\mathrm{A}$ ) is the base of Holocene marine sediments. They considered the Holocene marine sequence to be above horizon $A$, with a thickness and distribution shown in the isopach map in Figure 2-2. The sediments above horizon $A$ are yet to be confirmed as Holocene marine by dating of borehole samples.

Acoustic stratigraphy extends the Gubik Formation to the offshore of Harrison Bay. Craig and Thrasher (1982) tentatively identified three acoustic sequences in Harrison Bay that may correlate to the sequences observed by Reimnitz et al. (1972). A low angle unconformity observed on common depth point (CDP) profiles at a depth of $100 \mathrm{~m}$ represents the inferred base of the Gubik Formation (Craig and Thrasher, 1982). Craig and Thrasher (1982) recognized the upper boundary of the Pleistocene in interpretations of $3.5 \mathrm{kHz}$ profiles. They suggested that this boundary may be a remnant surface of the coastal plain that has been transgressed by Holocene marine deposits. The hummocky relief of the reflectors observed in $3.5 \mathrm{kHz}$ profiles may represent buried channels, thaw lakes, and a tundra thermokarst surface similar to the present coastal plain. Craig and Thrasher (1982) informally named the Pleistocene nonmarine deposit Unit A and interpreted an acoustically transparent unit above Unit $A$ to be Holocene marine deposits. Isopachs of the inferred Holocene marine unit thickens from 2 to 25 meters in a seaward direction. They interpreted an abrupt change from thin to thick Holocene sediments as a paleoshoreline. Craig and Thraser (1982) suggested that a Pleistocene marine sequence (Unit B) is distributed seaward of the shoreline feature beneath thick $(25 \mathrm{~m})$ Holocene marine deposits. The ages of Craig and Thrasher's (1982) acoustic sequences are tentative until the stratigraphy is dated.

Craig and Thrasher (1982) suggested that subsea permafrost and gas-bearing sediment may influence the acoustic character of shallow reflectors in Harrison Bay. Vralsted (1986) agreed that subsea permafrost and gas-bearing sediments affect the acoustic character and relief of reflectors. He correlates ice-bonded layers from borehole logs to strong flat acoustic reflectors. If the paleoshoreline observed by Craig and Thrasher (1982) is a permafrost feature, it may represent a change in the depth to the ice-bonded surface (Craig et al., 1985). The abrupt drop in reflector depth, originally interpreted as a buried bluff, may represent a drop off in the depth to ice-bonded sediments. Vralsted (1986) contended that where several reflectors are observed, such as seaward of the paleoshoreline, the subsurface may be more transparent to acoustical energy, thus deeper penetration is achieved. He suggests that a possible decrease in ice content would increase transmission of the acoustic signal deeper in the sub-bottom. This acoustic anomaly has yet to be confirmed as a paleoshoreline, gas, or subsea permafrost feature.

Seven distinct acoustic reflectors are identified on the inner Beaufort Sea shelf between Prudhoe Bay and the Canning River (Wolf et al., 1985). Of the seven reflectors, five are described as erosional unconformities. Two unconformities (surfaces 3 and 4) are extensive over the inner shelf and are interpreted as erosional surfaces of sea-level lowstands. The erosoional events were followed by sea-level transgression and the deposition of several meters of shallow marine sediment on the inner and middle shelf. These marine and deltaic deposits grade to fluvial outwash near the present coast. A structure contour of surface 4 (Figure 2-3) shows one of the major erosional unconformities (Wolf et al., 1985). Surface 3 is an older erosional surface that is similar to surface 4 (Figure 2-4). Surface 3 and 4 converge to the west of Prudhoe Bay until surface 4 onlaps and erodes surface 3 (Figure 2-4). Wolf et al. (1985) suggested that a hummocky reflector (surface 5) could 


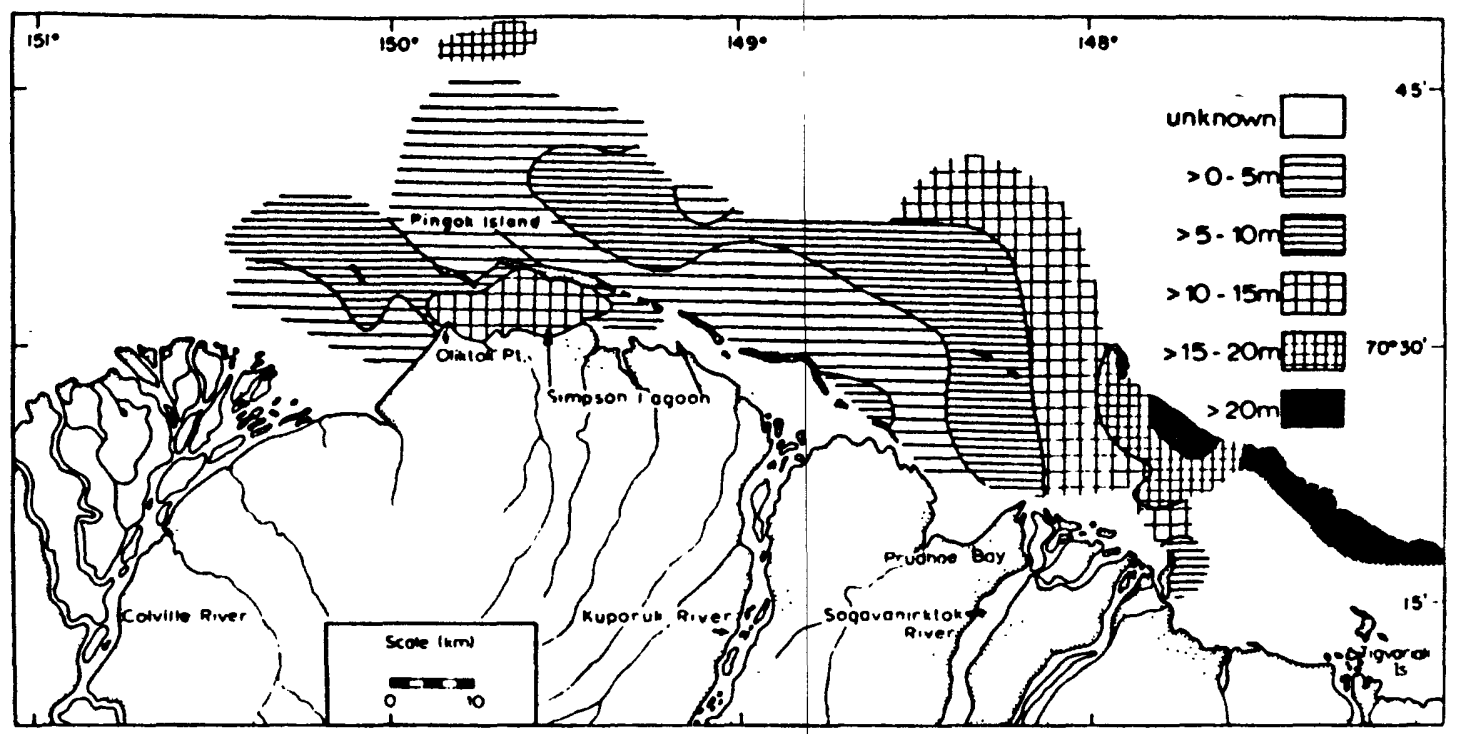

Figure 2-2. Tentative Holocene marine sediment isopach map for sediments above horizon A. Thicknesses are based on a sound velocity of $1500 \mathrm{~m} / \mathrm{s}$ (after Reimnitz et al., 1972).

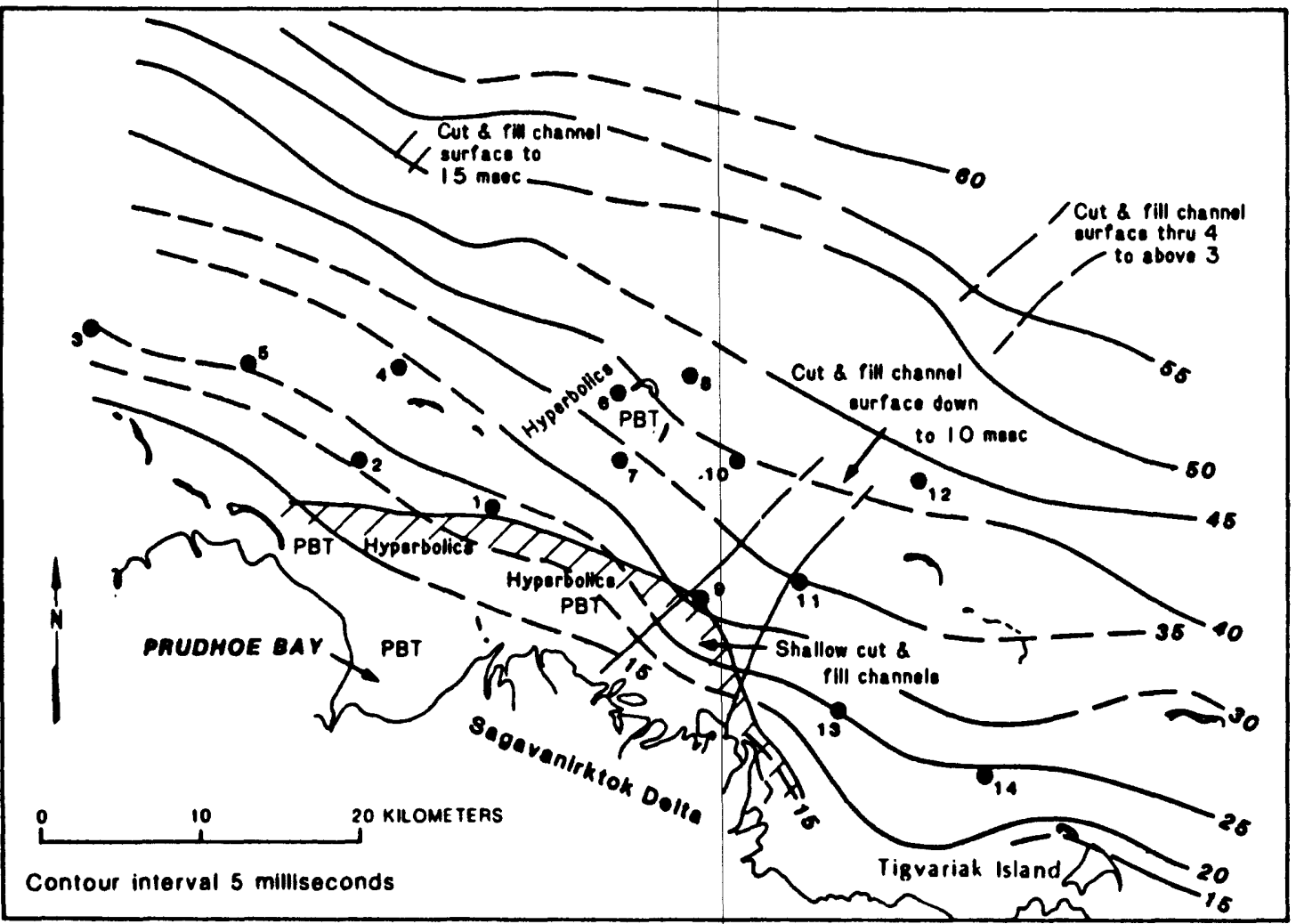

Figure 2-3. Structure contour of surface 4 (after Wolf et al., 1985). Borehole locations (Harding-Lawson, 1979) are shown with dots. The hachured area, labeled PBT hyperbolics, is a region where seismic profiles show numerous hyperbolic reflectors. Interpretations of the hyperbolic reflectors are discussed by Reimnitz et al. (1972), Neave et al. (1981), and Wolf et al. (1985). 


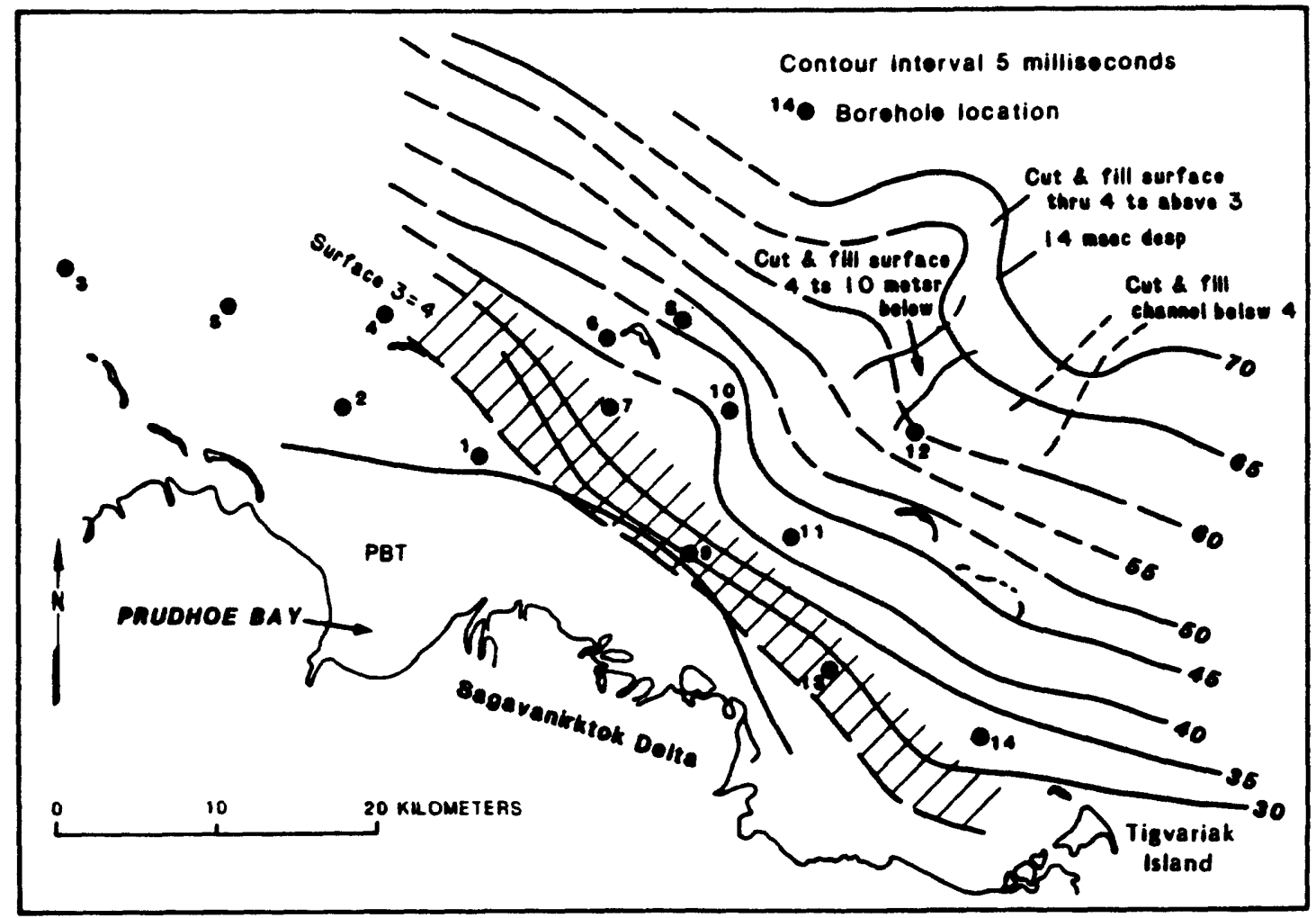

Figure 2-4. Structure contour of surface 3 (after Wolf et al., 1985). Borehole locations (Harding-Lawson, 1979) are shown with dots. The hachured area, labeled surface $3=4$, is where the erosional event that formed surface 4 has removed the deeper surface 3. PBT is a region where seismic profiles show numerous hyperbolic reflectors. Interpretations of the hyperbolic refiectors are discussed by Reimnitz et al. (1972), Neave et al. (1981), and Wolf et al. (1985). 
represent a remnant coastal plain surface. They also offered an alternative hypothesis, that the reflector could be from an ice or gas-bearing sediment interface. Another reflector they map as surface 5 ? is queried because of the uncertainty of the correlation to surface 5 . Sediments above surface 5 ? represent the distribution of Holocene marine deposits (Figure 2-5). The sequence above surface 5 ? is restricted to lagoonal and embayed regions where deposits are protected from the erosive action of sea-ice. Seaward of the barrier island chain, surface 5 ? does not exist and the sea-floor is an erosional surface. Surface 5 is located seaward of the barrier island chain and appears to be stratigraphically below surface 5 ?.

On the outer Beaufort Sea shelf, Dinter (1982) interpreted a strong acoustic reflector as the once subaerially exposed surface of the Late Wisconsin sea-level lowstand. Dinter (1982) named the deposit below the Pleistocene-Holocene unconformity Unit B and interpreted Unit B as a nonmarine deposit. Typically, a broad hummocky ridge, inferred to be a barrier chain that formed during the sea-level lowstand of the Late Wisconsin, is preserved along the seaward extent of Unit B. Unit B underlies an acoustically transparent seaward thickening wedge of Holocene sediment that Dinter (1982) called Unit A. He suggested that the Unit $A$ represents deposition that began after the maximum sea-level lowstand of the Late Wisconsin, thus part of Unit A may be older than the formal age of the Pleistocene-Holocene boundary of 10,000 years B.P. (Hopkins, 1975). Dinter (1982) indicated that up to $45 \mathrm{~m}$ of sediment comprise the Holocene transgressive wedge on the outer shelf. Unit A wedges out or is too thin to be acoustically resolved shoreward of the middle shelf.

Dinter (1985) showed that the Holocene sediment wedge is thickest in two structurally controlled basins near Camden Bay. Observations show that recent seismic events are active in the Camden Bay area; the western two thirds of the Beaufort shelf is over the more stable Arctic Platform and is not associated with recent seismicity (Biswas and Gedney, 1979; Grantz et al., 1983). Two structural depressions, termed the Eastern and Western Wedge Terranes, occur along the flanks of the Camden Anticline. Thick sequences of the Gubik Formation, including Units A, B, and older transgressive wedges and regressive units, form deposits in the Eastern and Western Wedge Terranes (Dinter, 1985). Dinter (1985) summarized his observations of deposits in the wedge terranes by comparing reflector termination elevations to global sea-level curves. He is unable to define the chronostratigraphy with confidence since ages of the acoustic sequences are not available.

The presence of surficial relict gravel deposits contradicts recent Holocene sedimentation on the outer shelf. (Barnes and Reimnitz, 1974; Naidu and Mowatt, 1974; Rodeick, 1979; Reimnitz et al., 1982). Dinter $(1983 ; 1985)$ contended that relict gravel deposits could have been deposited during the Holocene transgression. He considered a sedimentation model, similar to Rodeick's (1979) model, of ice-rafting transport and deposition to the outer shelf at the onset of transgression. Dinter $(1983 ; 1985)$ suggested that the ice-rafted sediment flux decreased in the latter part of the Holocene transgression. Field observations indicate that transport of gravel by ice-rafting on the outer shelf is presently insignificant (Barnes and Reimnitz, 1974; Naidu, 1974; Rodeick, 1979).

Correlation of acoustic and borehole stratigraphic relationships between the Canadian Beaufort shelf and the Alaskan Beaufort shelf suggest an older relative age of Unit A than Dinter $(1982 ; 1985)$ proposed (S.M. Blasco, personal communication, 1987). This evidence suggests that Dinter's (1985) correlation of acoustic sequences to sea-level curves might be shifted to a relatively older age; Unit A would be a Pleistocene deposit. 


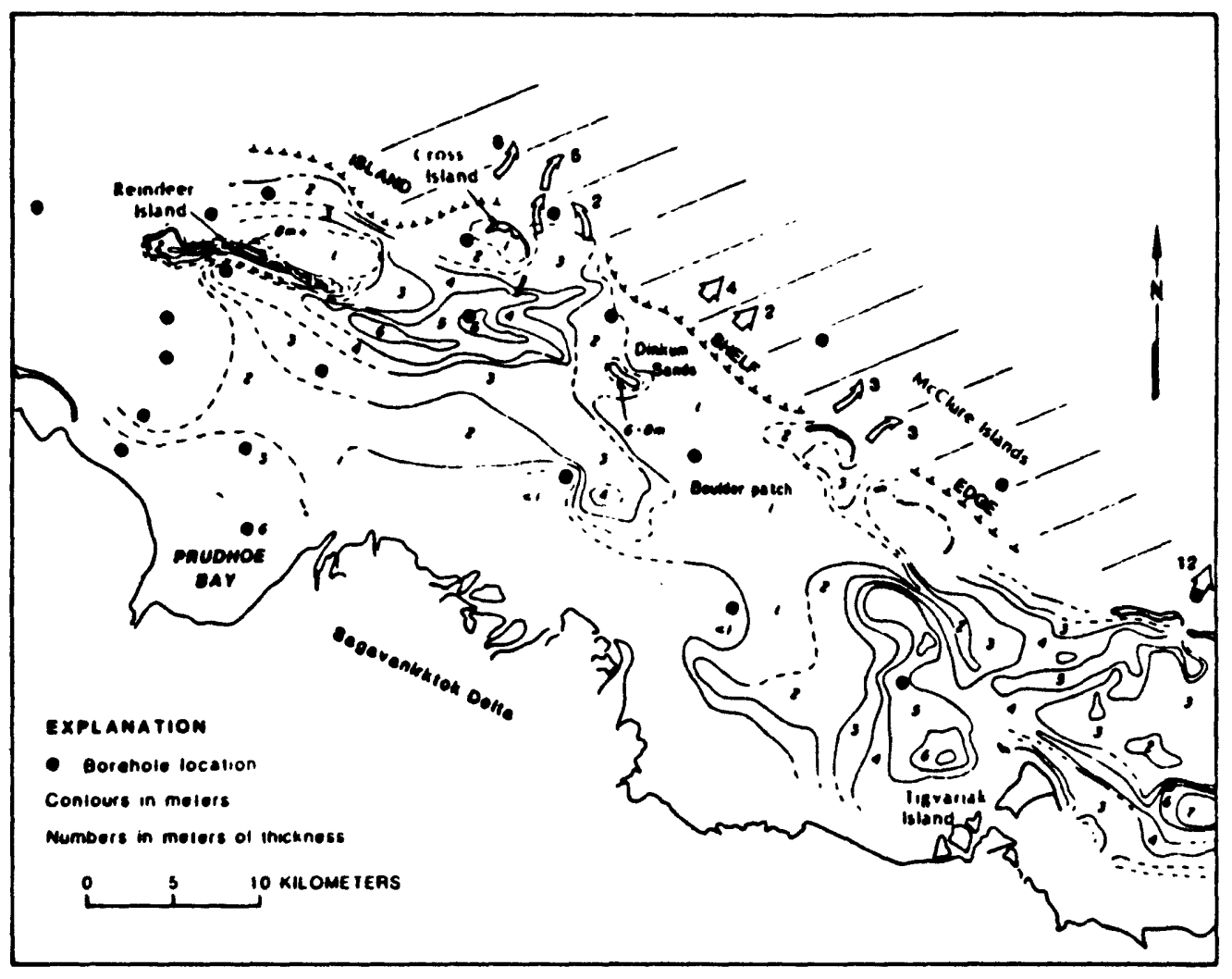

Figure 2-5. Isopach map of Holocene sediments between Surface 5? and the sea-floor. Borehole locations (Harding-Lawson, 1979) are shown with dots. Arrows and numbers indicate the location and incision depth of buried channels. Seaward of the dashed hachured line, the hachured area is an erosional sea-floor that lacks Holocene sediment (after Wolf et al., 1985). 
In general, previous investigators agree that Holocene marine sediments are a few meters thick or absent on the inner shelf. Several of the following processes may account for this observation:

1) Spring breakup of major North Slope rivers results in bypassing of the suspended load over sea-ice as much as $15 \mathrm{~km}$ on to the inner shelf (Barnes and Reimnitz, 1972; Reimnitz and Bruder, 1972; Walker, 1974; Cannon and Rawlinson, 1981). This process is one reason for thin delta front deposits on Alaskan Arctic deltas.

2) Flood waters that flow over sea-ice during spring breakup eventually enter holes and cracks (strudels) in the ice and result in scouring and cratering of the sea-floor (Reimnitz et al., 1974). Reimnitz et al. (1974) measured the dimensions of strudel scour craters with an echosounder. Craters are as much as $4 \mathrm{~m}$ deep and $20 \mathrm{~m}$ across. The strudel scour process may account for further erosion and reworking of delta front sequences. Reimnitz and Kempema (1982) suggested that Alaskan Arctic delta fronts may be entirely reworked to a depth of at least $2 \mathrm{~m}$ in a 2,300 year period. A chaotic reflector configuration may occur on acoustic profiles where strudel scour has reworked the sub-bottom sediments (Reimnitz et al., 1974).

3) Hydraulic sorting and erosion of sea-floor sediments also influence deposition of Holocene sediments. Landward of the $2 \mathrm{~m}$ bench, wave-induced currents rework delta front sediments during a 3 to 4 month open water season (Naidu and Mowatt, 1975). Landward of the $15 \mathrm{~m}$ isobath, storm currents rework sediments to depths of 10 's of $\mathrm{cm}$ (Barnes and Reimnitz, 1979).

4) Ice gouging from the plowing action of sea-ice keels frequently reworks and resuspends sediments. The most intense ice gouging occurs between the 20 and $60 \mathrm{~m}$ isobaths (Barnes and Reimnitz, 1974). The maximum depth of an ice gouge is measured at $4 \mathrm{~m}$ near the $20 \mathrm{~m}$ isobath in Harrison Bay, and the mean gouge depth is $0.56 \mathrm{~m}$ (Barnes et al., 1984). Continuous ice gouging of the sea-floor over long time periods may form shallow reflectors observed on the Beaufort Sea shelf (O'Conner, 1980; Reimnitz et al., 1982; Wolf et al., 1985). Reimnitz et al. (1982) contended that ice gouging processes negate the possibility of observing internal reflectors within a Holocene marine acoustic sequence. They deduced from this logic that the first reflector observed on acoustic records is the maximum thickness of the Holocene marine sequence. O'Conner (1980) referred to a sequence on acoustic reflection data from the Canadian Beaufort Sea as a paleoscour zone. He suggested this sequence was formed by pervasive ice gouging during the Holocene transgression. Wolf et al. (1985) suggested that such reflectors should not be confused with the Pleistocene-Holocene interface, since ice gouging may mix older Pleistocene sediments with Holocene marine deposits.

5) In the Camden Bay area, local Quaternary uplift restricts accumulation of Holocene marine deposits over structural highs (Reimnitz et al., 1982; Grantz et al., 1983).

Temporary Holocene marine deposition on the inner shelf occurs in several environments. Holocene marine deposits may accumulate in back barrier environments and protected embayments, as these areas are relatively sheltered from the erosive action of sea-ice (Wolf et al., 1985). Erosive spots are locally observed in lagoonal areas such as a boulder lag deposit located near Prudhoe Bay (Reimnitz and Ross, 1979). Reimnitz et al. (1985) suggested that most of the inner shelf is an erosional surface, and lagoons are temporary sediment traps. They indicated that some of the sediments deposited in lagoons are reworked and bypassed to the outer shelf and may eventually be deposited in Canada Basin. Holocene marine deposits infill strudel scour craters which would increase Holocene 
deposits locally. Measurements of bedload transport from infilling rates of Strudel scour craters indicate that craters fill within 2 to 3 years (Reimnitz and Kempema, 1982).

Evidence from high-resolution acoustic stratigraphy suggests that the Gubik Formation extends from the Arctic Coastal Plain Province to the Beaufort Sea shelf. Sparker and CDP profiles show the inferred base of the Gubik Formation. Boomer and $3.5 \mathrm{kHz}$ profiles identify transgressive and regressive Quaternary units that may correlate to the Gubik Formation on land. Present correlations are tentative until the acoustic sequences can be dated. The previous work done on acoustic stratigraphy indicates that Quaternary stratigraphic units are layered, dip seaward, and usually thicken seaward, except where structural deformation is active in the Camden Bay region. Reflectors between Prudhoe Bay and the Canning River are commonly truncated at the sea-floor on the inner shelf. This suggests the inner shelf is erosional or at least nondepositional in this region.

\subsection{Offshore Quaternary Borehole Stratigraphy}

Investigations of the stratigraphy of nine boreholes drilled as part of the Outer Continental Shelf Environmental Assessment Program (OCSEAP) (Hopkins, 1977; Chamberlain et al., 1978; Hopkins et al., 1979; Smith and Hopkins, 1979) and twenty additional boreholes acquired by the U.S. Geological Survey (Harding-Lawson, 1979; Hartz et al., 1979; Smith, 1985; 1986) contribute to the knowledge of the nearshore Quaternary stratigraphy between the Kuparuk and Canning Rivers. In general, the upper sections of some of the core samples indicate up to $10 \mathrm{~m}$ of Holocene marine mud and fine sand are deposited over Holocene beach sand. Other boreholes show older, often overconsolidated (Chamberlain et al., 1978), marine muds that Hartz et al. (1979) suggested to be Sangamon marine and Flaxman Member deposits. Marine sediments overlie Pleistocene age outwash sand and gravel. Deeper yet, in the boreholes, are thick alluvial gravels that may reach depths of at least $100 \mathrm{~m}$ (Smith et al., 1980).

A paleovalley system is believed to exist on the inner Beaufort Sea shelf (Hopkins, 1977). This hypothesis is based on borehole stratigraphy and bathymetry (Smith et al., 1980). The boreholes show a trough that is ponded with Holocene marine sediment up to $10 \mathrm{~m}$ thick and filled with a thick deposit $(>90 \mathrm{~m})$ of Pleistocene gravel. Smith et al. (1980) suggested a paleovalley depositional model that relates subsea permafrost distribution and thickness. Holocene marine sediments mantle thick non-bonded gravels. The non-bonded gravel represents paleovalley fill. The confining margins of the paleovalleys, the flanks of the trough, are defined in boreholes that show Pleistocene marine sediments deposited over ice-bonded gravels. Their depositional model suggests that a paleovalley extends on to the Beaufort shelf from the Sagavanirktok River (Smith et al., 1980). The Sagavanirktok paleovalley may turn westward from Prudhoe Bay and eventually meet with paleovalleys of the Kuparuk and Colville Rivers (Hopkins, 1987). A subsurface lithologic facies change between Oliktok Point and Thetis Island shows sand and gravel to the east and mud in the west (Hopkins, 1987). In addition, industry shothole lithologic logs (Erk Reimnitz, unpublished data) suggest the same trend exists for transects that extend from the coastal plain to the seaward side of Thetis Island (see Briggs, 1983). It is unknown if this trend represents the western edge of the Colville River paleovalley or is related to some other geologic boundary. The upper $30 \mathrm{~m}$ of the coastal plain, south of Harrison Bay, increases in grain size to the east (Mead and Brockett, 1982).

A detailed paleostratigraphic analysis, from seven of the twenty boreholes acquired west of Prudhoe Bay by the U.S. Geological Survey (Harding-Lawson, 1979), defines twelve depositional units (Smith, 1985). This study uses textural, microfaunal, and isoleucine epimerarization to establish ages and depositional environments for the sedimentary units. 
The sedimentary units may represent up to eight transgressive sequences that interbed fluvial and glaciofluvial sediments ranging from Pliocene to Holocene age. Smith (1986) informally named these units and correlated them to acoustic stratigraphy. The Leffingwell Lagoon Unit (Middle Pleistocene) correlates to the acoustic sequence between surface 3 and 4 (Figures 2-3 and 2-4) (Wolf et al., 1985). The contacts of the Leffingwell Lagoon Unit confirms the erosional unconformity interpretations of surfaces 3 and 4 . The Maquire Island Unit (Late Pleistocene) overlies surface 4. In two boreholes located in Stefansson Sound, the Cross Island Unit contains Flaxman-like deposits that underlie the Stefansson Sound Unit (Holocene). The five remaining boreholes located seaward of the barrier islands do not contain the Stefansson Sound Unit which is consistent with the erosional sea-floor that occurs on the inner shelf seaward of the islands (Wolf et al., 1985). Holocene marine deposits of the Stefansson Sound Unit correlate with the acoustic sequence above surface 5? (Figure 2-5) (Wolf et al., 1985).

\subsection{Subsea Permafrost and Gas-bearing Sediments}

Ice-bonded subsea permafrost exists in the study area (Hopkins and Hartz, 1978b; Osterkamp and Harrison, 1978a and 1978b; Morack and Rogers, 1984; Neave and Sellmann, 1984; Vralsted, 1986) as do gas-bearing sediments (Boucher et al., 1980; Craig and Thrasher, 1982; Grantz et al., 1982). Gas and ice in the sub-bottom sediments can complicate acoustic stratigraphic interpretation. Ice or gas-bearing sediments produce significant reflection coefficients because of their large acoustical impedance contrasts. Ice or gas confined by stratigraphy enhances reflectors of geologic features. Gas and ice-bearing horizons may be misinterpreted as stratigraphic horizons if gas and ice interfaces do not conform to stratigraphy. Also, gas may attenuate the acoustic signal and cause voids in the data. For the above reasons, I include a brief review of subsea permafrost and gas-bearing sediments in this report.

Temperature alone defines subsea permafrost. Permafrost is any ground material that maintains a negative temperature $\left(<0^{\circ} \mathrm{C}\right)$ continually for two or more years (Muller, 1947). Subsurface sediment temperatures on the Beaufort shelf are often negative; however, the sediments may not be ice-bearing. Salinity increase from sea water intrusion can depress the freezing point so that sediments may be partially-bonded or non-bonded.

Subsea permafrost can also be described visually by the ice content of the sediment. Sediments are described as ice-bearing when ice is present. This is a qualitative term that does not indicate the volume of ice present. Sediment that contains enough ice volume to bond sediment is called ice-bonded. Partially-bonded permafrost contains both water and ice phases within the sediments, and non-bonded permafrost lacks ice content.

Ice-bonded subsea permafrost is relict having formed when the shelf was subaerially exposed during sea-level lowstands, and climate conditions were favorable for permafrost to aggrade in the sediments. Subsequent transgressions that flood the shelf will thaw permafrost if the sea water temperature is positive $\left(>0^{\circ} \mathrm{C}\right)$ or if salt intrudes into the subsurface sediments. It is shown that subsea permafrost is preserved where overconsolidated muds essentially cap the permafrost with an impermeable layer (Smith et al., 1980).

Ice-bonded frozen sediments can form in the marine environment. Sediments of the sea-floor may freeze during sea-ice formation. Hypersaline water, formed by salt rejection as sea-ice forms, sinks to the bottom and freezes the relatively less saline sediment pore water (Sellmann and Hopkins, 1983; Reimnitz et al., 1985). Inside of the $2 \mathrm{~m}$ isobath, the sea-floor may freeze as grounded fast ice freezes directly to the seabed (Barnes and 
Reimnitz, 1973). These processes that freeze the sea-floor seem to be annual, thus frozen surficial sediments are not preserved for the entire year (Reimnitz et al., 1985). This type of freezing of the sea-floor is not defined as permafrost. Sellmann and Hopkins (1983) discussed another process that may form ice-bonded subsea permafrost under the influence of major rivers. River discharge may decrease salinities of sea water near river deltas. Coarse grained deposits may act as aquifers to the "freshened" sea water. The interstitial water associated with the coarse grained deposits may freeze to produce ice-bonded permafrost. This type of subsea permafrost may occur in association with the Mackenzie Delta in the Canadian Beaufort and possibly other Alaskan Arctic deltas (Sellmann and Hopkins, 1983).

Acoustic and seismic refraction methods detect ice-bearing sediment on the Canadian and Alaskan Beaufort shelf. Seismic refraction methods are used to measure high compressional wave velocities that are associated with ice-bonded permafrost (Hunter et al., 1974; Morack and Rogers, 1984; Neave and Sellmann, 1984). Velocities higher than cutoff points are interpreted as ice-bonded permafrost. Depending on the study, the cutoff point can range from $2000 \mathrm{~m} / \mathrm{sec}$ to $2400 \mathrm{~m} / \mathrm{sec}$. Acoustic reflection methods are employed in detecting subsea permafrost. O'Conner (1977) proposed the term acoustic permafrost (APF) to identify subsea permafrost with high-resolution acoustic profiles. Several types of APF are hummocky APF islands, stratigraphically controlled APF, continuous, and discontinuous APF (O'Conner, 1981; Blasco, 1983). High amplitude hummocky reflectors that occur in isolated patches or "islands" usually correspond with massive coarse grained deposits (Blasco, 1983). APF reflectors may be confined to relatively coarse grained stratigraphic horizons. Discontinuous APF results from discontinuous permafrost or partially-bonded permafrost. Detection of subsea permafrost with reflection and refraction methods is useful in measuring the depth to ice-bonding as well as the aerial extent of ice-bearing sediments. Visual evidence from boreholes must be used to confirm acoustic methods.

Several boreholes encounter ice-bearing sediments in Harrison Bay, Prudhoe Bay, and Stefansson Sound. In addition, thermal probes infer ice-bearing sediments exist in the study area. In Prudhoe Bay and Stefansson Sound, the depth to ice-bonded sediments may be shallow in the subsurface $(<10 \mathrm{~m})$ or as deep as $140 \mathrm{~m}$. The variation in thickness of non-bonded permafrost is explained by the distribution of non-bonded paleovalley fill (Hopkins, 1977). Permafrost is preserved near the surface where overconsolidated muds are distributed between paleovalleys. Borehole temperature profiles infer that ice-bearing sediments are present at $12 \mathrm{~m}$ below the sea-floor in Harrison Bay (Osterkamp and Harrison, 1982). Industry boreholes confirm ice-bearing and ice-bonded sediments 6 to $9 \mathrm{~m}$ below the sea-floor in Harrison Bay (EBA Engineering and McClelland Engineers, 1982).

Gas-bearing sediments may appear as high amplitude reflectors, velocity pulldown, or attenuated (acoustically turbid) zones on acoustic profiles. Gas-enhanced reflectors and acoustically turbid zones occur on the middle and outer Beaufort shelf (Grantz et al., 1982). On the inner shelf, high amplitude reflectors, high frequency attenuation, and reflector pulldown imply that shallow gas occurs. Craig and Thrasher (1982) showed that gas seeps are associated with shallow faults in Harrison Bay. Neave and Sellmann (1984) also mapped possible shallow gas in Harrison Bay based on attenuation of high frequency acoustic signals. A borehole (Harding-Lawson, 1979) confirms gas corresponding to a high amplitude reflector in the subsurface of Stefansson Sound (Boucher et al., 1980).

Gas hydrates, a form of clathrate, are composed of molecules of gas that are trapped within the expanded lattice of water molecules (Macleod, 1982). Gas hydrates occur in 
some deep ocean sediments and permafrost areas. Deep water gas hydrate reflectors occur on the outer Beaufort slope below $300 \mathrm{~m}$ (Grantz et al., 1982). Gas hydrates are detected onshore in the Prudhoe Bay region at or below the permafrost table (Kvenvolden and McMenamin, 1980; Collett, 1983). Neave and Sellmann (1982) suggested that shallow gas in Harrison Bay may originate from gas hydrates associated with underlying degrading permafrost. They note that in situ formation of biogenic gas could also be the source for shallow gas-charged sediments. O'Conner (1980) indicated that large shallow gas concentrations occur in zones of degrading permafrost on the Canadian Beaufort shelf.

\section{DATA BASE \\ 3.1 High-resolution Acoustic Refiection Data}

The U.S. Geological Survey, Branch of Pacific Marine Geology, provided most of the high-resolution acoustic reflection profiles used in this report (P.W. Barnes and $E$. Reimnitz, unpublished data). The data consisted of acoustic reflection profiles that used primarily boomer type acoustic energy sources. Wolf et al. (1985) summarized the data aquisition on the inner Beaufort Sea shelf. Acoustic data collection began in 1970 and continued until 1983. An EG\&G Uniboom system was employed in 1972 and was replaced with an ORE Geopulse system in 1983 . The ORE Geopulse generally produced higher quality data than the the Uniboom system. The Geopulse system's higher power output and broad band frequency provided deeper penetration while maintaining resolution. The boomer systems operated with various parameters for different lines and field seasons. In general, the Uniboom transmitted pulses with a peak frequency of $2.5 \mathrm{kHz}$ while the Geopulse operated within a bandwidth of 2 to $7 \mathrm{kHz}$. Acoustic sources were usually fired at $0.25 \mathrm{~s}$ intervals. The signals received were filtered within a bandwidth of 500 to 2000 $\mathrm{Hz}$ before being recorded on chart paper at a $0.25 \mathrm{~s}$ sweep rate. Some additional $7 \mathrm{kHz}$ tuned transducer data were acquired from a Raytheon system.

The U.S. Geological Survey, Conservation Division, acquired acoustic profiles as part of the Oil and Gas Lease Sale 71 (U.S. Geological Survey, 1980). Microfilm copies of this data were obtained from the National Geophysical Data Center in Boulder, Colorado (see Appendix 2). Arrangements were made to observe the original acoustic profiles through the Minerals Management Service (formerly U.S. Geological Survey, Conservation Division). Sub-bottom profiles were collected with a $3.5 \mathrm{kHz}$ tuned transducer transmitting at 0.25 s intervals and recording at a $0.25 \mathrm{~s}$ sweep rate. An EG\&G Uniboom system was operated at a $0.25 \mathrm{~s}$ fire rate at $500 \mathrm{~J}$ power output. The data were filtered from 330 to $1100 \mathrm{~Hz}$ and recorded at a $0.25 \mathrm{~s}$ sweep rate.

Additional acoustic profiles of the outer Beaufort shelf were obtained from a 1977 U.S. Geological Survey data set from the outer Besufort shelf (Grantz and Greenburg, 1981). A hull mounted EG\&G Uniboom acoustic energy source was fired at $1 \mathrm{~s}$ intervals with a peak frequency of $1 \mathrm{kHz}$. The data received were filtered between 300 and $1500 \mathrm{~Hz}$ and recorded at a $0.5 \mathrm{~s}$ sweep rate.

Appendix 2 provides information on obtaining copies of the acoustic profiles referred to in this report.

\subsection{Trackline Distribution}

Navigation for the acoustic profiles included about $1650 \mathrm{~km}$ of trackline that crossed the $7250 \mathrm{~km}^{2}$ study area. The data that were collected by the U.S. Geological Survey over a 12 year period was compiled into a single base map (Figure 3-1). Boomer data exist for each trackline, whereas $3.5 \mathrm{kHz}$ data used in this study came only from a 1980 U.S. 


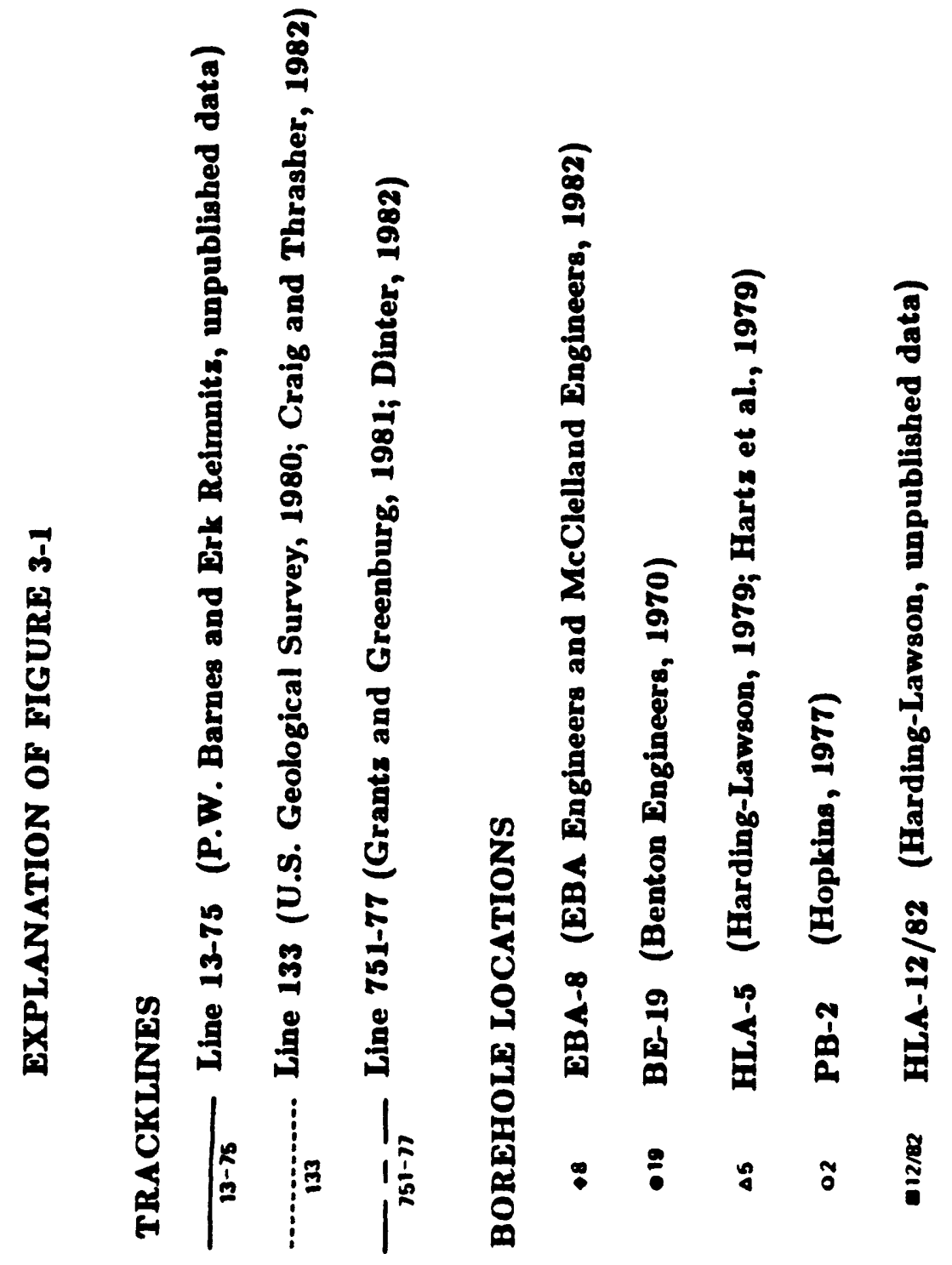




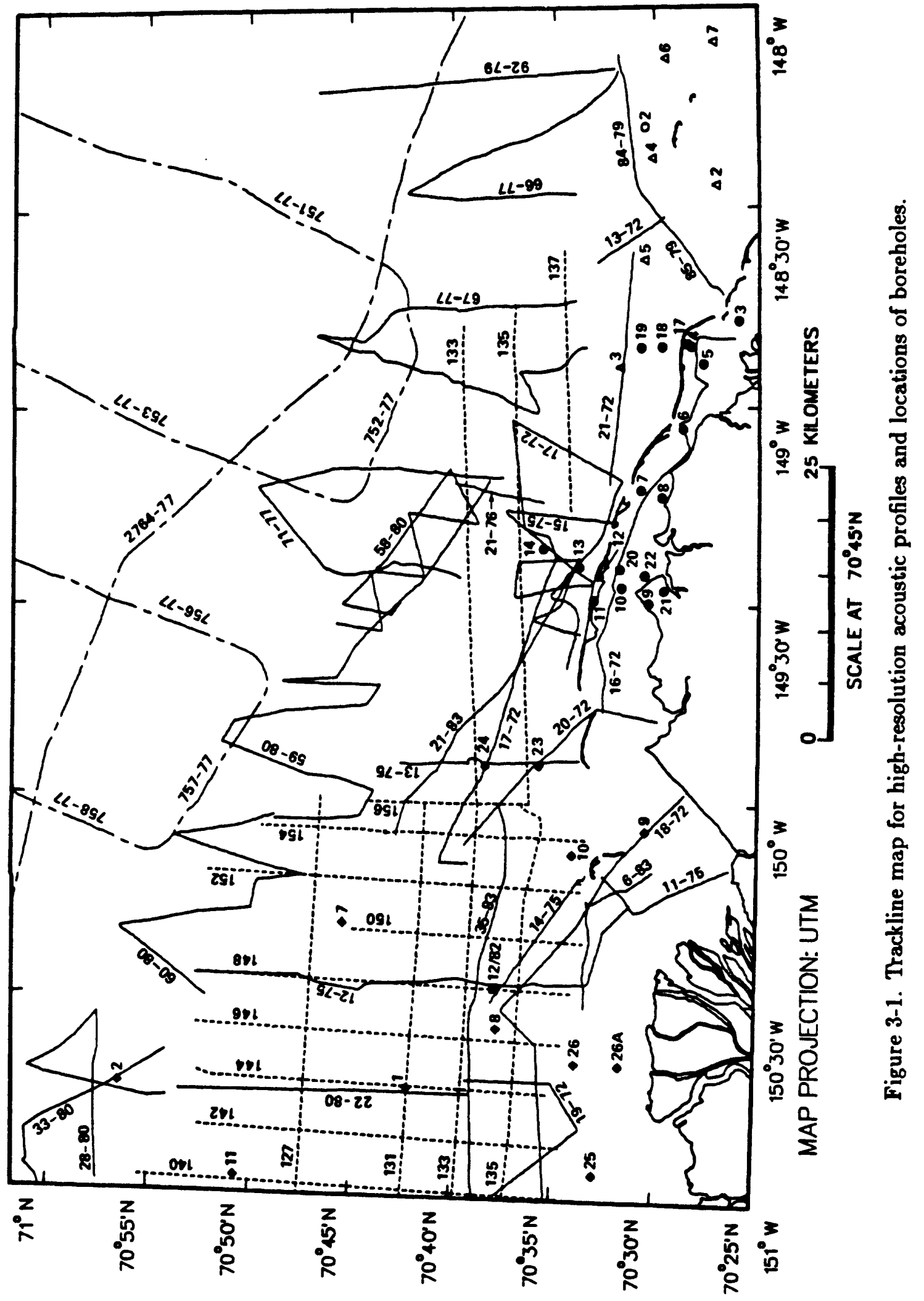


Geological Survey data set (U.S. Geological Survey, 1980). The tracklines for additional $7 \mathrm{kHz}$ data (P.W. Barnes and E. Reimnitz, unpublished data) were not shown in Figure 3-1.

The U.S. Geological Survey collected acoustic profiles from 1972 through 1983, (P.W. Barnes and E. Reimnitz, unpublished data). A random pattern of about $820 \mathrm{~km}$ of tracklines resulted, because acoustic profiles were collected ancillary to other investigations. Site specific projects resulted in tracklines that cross several shoals. Weather conditions and sea-ice distribution often dictated the coarse of the survey vessel.

Data from about $480 \mathrm{~km}$ of tracklines were selected to be used in this study from a 1980 U.S. Geological Survey data set (U.S. Geological Survey, 1980). The survey was conducted to specifically obtain geophysical data. Tracklines of this survey grid were spaced at $5 \mathrm{~km}$ intervals. This resulted in a nearly complete grid of data, except where equipment malfunctioned.

In 1977 the U.S. Geological Survey conducted a reconnaissance geophysical survey over the outer Beaufort shelf (Grantz and Greenburg, 1981). About $350 \mathrm{~km}$ of trackline shows the navigation of the Uniboom data was used in this study (Figure 3-1). Four Uniboom profiles, spaced 30 to $40 \mathrm{~km}$ apart, run perpendicular to the shelf break. A shelf parallel line was selected to tie the four lines together. Three lines $(751,752$, and 753$)$ were copied from microfilm and were interpreted in more detail than the others.

\subsection{Acoustic Data Quality}

The acoustic reflection data used in this study ranged from good to poor quality. Vertical resolution and penetration depth varied between surveys of different years depending on the type of equipment used and the parameters they were operated with. Variations in the recorder sweep speed, pulse length, and frequency component all affected the resolution obtained on the acoustic profiles. These parameters were often different from survey to survey between 1972 and 1983; the records obtained display different resolutions. This complicated the interpretation and comparison of data. The frequency component of a sub-bottom profiling system determined the penetration depth and resolution of a particular survey. Peak frequencies of acoustic energy sources and bandwidths of received signals varied between surveys. Records that obtained good penetration were generally not as useful for interpreting shallow reflectors and closely spaced reflectors. The systems that were operated at relatively higher frequencies were more useful for interpreting closely spaced reflectors. Boomer systems operated in optimum conditions can penetrate to depths of $100 \mathrm{~m}$ while maintaining a vertical resolution of about $0.5 \mathrm{~m}$ (Sylwester, 1983). Vertical resolution of uniboom records on the outer shelf are estimated to be about $5 \mathrm{~m}$ due to the trailing pulse of the source signal (Dinter, 1982). Uniboom and Geopulse records on the inner shelf have higher resolution (about $1 \mathrm{~m}$ ), because higher frequencies and lower power outputs were used. Also, sweep rates of $0.5 \mathrm{~s}$ for the outer shelf versus $0.25 \mathrm{~s}$ for the inner shelf provided higher vertical resolution on the inner shelf. Tuned transducer systems operated at $3.5 \mathrm{kHz}$ and $7 \mathrm{kHz}$ can penetrate up to $30 \mathrm{~m}$ and resolve reflecting interfaces within 10's of cm apart (Sylwester, 1983). Craig and Thrasher (1982) considered resolutions to be about $1 \mathrm{~m}$ for $3.5 \mathrm{kHz}$ data and $2 \mathrm{~m}$ for Uniboom data. They indicate that the Uniboom records are degraded from operations at high power $(500 \mathrm{~J})$ in shallow water.

Penetration depth was also dependent upon the acoustical response of the sediment. Poor acoustical response was caused by attenuation of the acoustic signal and the amount of acoustic energy that was reflected and transmitted in the subsurface. Interfaces with 
high acoustical impedance contrast reflected most of the acoustic energy. This limited further penetration of the signal. There were several factors that accounted for poor acoustical response. Acoustic permafrost (APF) may reflect most of the incident acoustic energy and thus mask deeper reflectors. Interstitial gas may enhance reflectors or produce a reflector where a gas front does not conform to stratigraphy. Gas may also attenuate the acoustic signal and leave voids in the data. As mentioned earlier, gas and subsea permafrost is common throughout the study area, and thus caution was needed when interpreting the data.

Another pitfall was common to the high-resolution acoustic profiles. The quality of shallow water data was degraded by multiples of the sea-floor. Multiples masked most of the acoustic record in water less than $5 \mathrm{~m}$ deep.

Overall, the data were acceptable for interpretation, and regional reflectors could be traced with confidence. Trackline density allowed detailed mapping in some areas while large gaps existed elsewhere.

\subsection{Borehole Data}

Borehole information from several sources (Benton Engineering, 1970; Hopkins, 1977; Harding-Lawson, 1979; Hartz et al., 1979; EBA Engineering and McClelland Engineers, 1982) was correlated to the acoustic stratigraphy. Proprietary borehole samples (HardingLawson, unpublished data) from Harrison Bay were dated with ${ }^{14} \mathrm{C}$ analysis. Figure 3-1. shows the borehole positions in relation to the tracklines.

The boreholes were sampled at varying intervals. Benton Engineering (1970) logged borehole lithology continuously. Cohesive sediments were sampled and the wash of noncohesive sediments were logged. Boreholes drilled during 1977 in Prudhoe Bay (Hopkins, 1977) were sampled at intervals that ranged between 0.5 to $6 \mathrm{~m}$, and wash samples were logged continuously. Boreholes drilled by Harding-Lawson (1979) and Hartz et al. (1979) sampled cohesive sediments almost continuously and noncohesive sediments every $3 \mathrm{~m}$. Harrison Bay boreholes (EBA Engineering and McClelland Engineers, 1982) were sampled about every $1.5 \mathrm{~m}$.

\section{METHODS OF INTERPRETATION}

The interpretation of the acoustic stratigraphy included the following steps: 1) major reflectors and acoustic sequences were defined, 2) lithology from boreholes were correlated to the acoustic stratigraphy, 3) internal reflectors and their reflector character were analyzed, and 4) the paleogeography and depositional history were constructed.

The first step, acoustic sequence analysis, was similar to seismic sequence analysis described by Mitchum et al. (1977). The acoustic sequence analysis was done by defining acoustic sequences and their sequence boundaries. An acoustic sequence is an acoustic image of a depositional sequence. "A depositionsl sequence is a stratigraphic unit composed of a relatively conformable succession of genetically related strata and bounded at its top and base by unconformities or their correlative conformaties (Mitchum et al., 1977) ." Depositional sequences were used as the basic unit to construct a stratigraphic framework. Defining depositional sequences was important, because sequences represent deposits that have chronostratigraphic significance. Internal reflectors within sequences can be interpreted to indicate depositional facies. Identifying sequence boundaries was important, because the boundaries define the geometry and distribution of sequences. Also, the sequence boundaries usually represent erosional events or nondepositional hiatuses. Many of the terms used to describe the data were referenced from Mitchum (1977). 
Reflectors were traced on the continuous acoustic profiles and labeled numerically in ascending order beginning at the oldest acoustic reflector. Reflector numbers were labeled in intervals of ten, so intermediate reflectors could be labeled later. The numbers selected to label reflectors were based on correlations with numbers assigned to acoustic reflectors that were mapped east of Prudhoe Bay by Wolf et al. (1985). The reflector names are abbreviated in the text. For example, Reflector 50 is called R50.

Structure contour maps and an isopach map were constructed to show the aerial extent of acoustic sequences. Continuous reflectors (sequence boundaries) were correlated from line to line by comparing two-way travel times (TWT) where tracklines crossed. The TWT to reflectors was digitized by hand and contours were drawn on the structure maps. The thickness of the youngest sequence was digitized manually and converted from TWT to thickness. A sound velocity of $1600 \mathrm{~m} / \mathrm{s}$ was assumed, thus $1 \mathrm{~ms}$ TWT is equal to $0.8 \mathrm{~m}$. The sediment overburden was then contoured as an isopach map. Maps also illustrated smaller acoustic sequences such as cut and fill channels and prograding depositional sequences.

Borehole correlations with acoustic profiles were done by converting depths to TWT, assuming a velocity of $1600 \mathrm{~m} / \mathrm{s}$ for the sub-bottom, and superimposing the borehole on to the acoustic record. Lithologic contacts and contacts between non-bonded and icebearing sediments were correlated to reflectors and sequence boundaries; lithologic units were correlated to acoustic sequences. As borehole logs were available only for the inner shelf, verification of the acoustic interpretations was not possible for the middle and outer shelf region.

Five cross-sections were constructed normal to the coast to illustrate the two-dimensional stratigraphic framework. The cross-sections were simplified from the acoustic profiles and included key boreholes where possible.

The depositional history was interpreted from the structure maps, borehole analysis, and cross-sections. Depositional environments and sea-level history were considered based on the combined analysis. Two borehole samples were dated with ${ }^{14} \mathrm{C}$ to determine the age of the youngest acoustic sequence. Additional ages of acoustic sequences were determined based on correlations of the acoustic stratigraphy to previous studies.

\section{RESULTS AND INTERPRETATION}

\subsection{Acoustic Stratigraphy}

A stratigraphic framework was constructed from the interpretation of high-resolution acoustic profiles (Figure 5-1). Five laterally continuous reflectors (sequence boundaries) are mapped in the study area. Reflectors are labeled R50 through R10, where R10 is the oldest sequence boundary. Major reflectors with varying reflector amplitudes are interpreted as erosional unconformities. As reflectors are traced laterally, their reflection amplitudes sometimes decrease until the reflector is not observed; however, the reflector usually appears again in an updip or downdip direction. Varying reflector amplitude over distances is expected of an erosional surface. This acoustic character was considered when mapping reflectors. Reflectors were assumed to correlate by projecting one reflector to another at a constant dip angle. This interpretive method is justified, because the stratigraphy appears relatively flat and structurally undeformed. Sequence boundaries define at least five acoustic sequences. The sequences were named with letters, $A$ through $E$, where Sequence $E$ is the oldest depositional unit. The correlation of 13 borehole logs to acoustic profiles are illustrated in Appendix 3 (Figures 11-1 through 11-18). The 


\begin{tabular}{|c|c|c|}
\hline $\begin{array}{c}\text { ACOUSTIC } \\
\text { SEQUENCES }\end{array}$ & $\begin{array}{c}\text { SEQUENCE } \\
\text { BOUNDARIES }\end{array}$ & QUERIED \\
\hline & $\begin{array}{l}\text { Upper: Sea-floor } \\
\text { Lower: R50 }\end{array}$ & Sea-floor \\
\hline & $\begin{array}{l}\text { Upper: R45, R50, Sea-floor } \\
\text { Lower: } \mathbf{R 2 0}, \mathbf{R 3 0}, \mathbf{R 4 0}, \\
\mathbf{R 3 0}=\mathbf{R} 40\end{array}$ & R45, * \\
\hline & $\begin{array}{l}\text { Upper: R40 } \\
\text { Lower: R30 }\end{array}$ & $\begin{array}{l}\text { R40(?) } \\
\text { R30(?) }\end{array}$ \\
\hline & $\begin{array}{l}\text { Upper: } \mathbf{R 3 0}, \mathbf{R 3 0}=\mathbf{R 4 0} \\
\text { Lower: } \mathbf{R 2 0}\end{array}$ & $\begin{array}{l}\text { R30(?) } \\
\text { R20(?) }\end{array}$ \\
\hline$F$ & $\begin{array}{l}\text { Upper: } \begin{array}{l}\text { R20 and Younger } \\
\text { Unconformities }\end{array} \\
\text { Lower: } \text { R10 }\end{array}$ & R20(?) \\
\hline Prograding Sequence & Upper: R10 & \\
\hline
\end{tabular}

- R20(?), R30(?), R40(?) may define the lower boundry of Sequence B

Figure 5-1. Generalized stratigraphic column showing the order of acoustic sequences and sequence boundaries. Acoustic sequences were bounded by sequence boundaries. Sequence boundaries were major reflectors $(R)$ that represented unconformities. Reflectors were queried when correlations to known reflectors was not possible. Sequence $A / B$ and its lower sequence boundary (R45) was placed in the queried column, because the stratigraphic relationship to Sequences $A$ and $B$ was uncertain. 
borehole locations are plotted on Figure 5-2. Sequence $C$ and Sequence $A / B$ are not penetrated by the boreholes. Also, R30, R40, R45, and queried reflectors lack borehole information. Cross-sections (Plates 1 through 3 ) are referenced throughout the description of the acoustic sequences and sequence boundaries. Locations of the cross-sections are shown on Figure 5-2. I have described and suggested interpretations for each acoustic sequence beginning with the oldest deposit, Sequence $\mathrm{E}$.

\section{Acoustic Sequence $\mathbf{E}$}

Sequence $\mathrm{E}$ is bounded by R10 at its base, and its upper boundary is limited by R20 or younger onlapping unconformities (Plates 1 and 2, Cross-sections A, B, and C). The lower boundary of Sequence $E(R 10)$ is identified only on low frequency boomer records. R10 at the base of Sequence $E$ is at the upper boundary of a deeper sequence of prograding clinoforms. The upper boundary of Sequence $E$ is defined by more than one refiector. Younger sequences onlap and erode Sequence $E$ in places. The onlapping of younger sequences indicate that Sequence $E$ has been exposed to at least 4 erosional events since deposition. Sequence $E$ may be as thick as $45 \mathrm{~m}$ in the Simpson Lagoon sub-bottom and appears to thin in a seaward direction.

The surface of Sequence $\mathrm{E}$ is broad and convex. The two-way travel time (TWT) to the oldest erosional unconformity (R20) that berels Sequence E is contoured in Figure 5-3. R20 dips seaward and to the northwest in eastern Harrison Bay. A decrease of the R2O amplitude to the west may be due to a lithologic facies change in Sequence $E$ from coarse grained in the east to fine grained in the west. North of Spy Island, R20 dips seaward steeper than normal until the reflector is abruptly terminated (Plate 2, Crose-section C). This termination of R20 may represent an erosional truncation of the unconformity. The relatively high relief of Sequence $E$ at this location has resulted in the preservation of a bank-like form. The buried bank of Sequence $E$ may have been more resistant to erosional events and subsequent transgressions than the rest of the sequence. Sequence $E$ deposits within the bank would have to contain coarser grain sizes compared to the rest of Sequence $E$ for the erosion resistant bank to form. The eastern limit of $R 20$ and Sequence $E$ is not well defined. Sequence $E$ probably extends further to the east than is mapped (Figure $5-3)$. In the eastern part of the study area, Sequence $D$ onlaps Sequence $E$. The upper boundary of Sequence D (R30=R40) represents two erosional events, R30 and R40 (Plate 1, Cross-section A). R30=R40 is where R40 truncates and has eroded R30 offahore of Sequence $E$. R30=R40 truncates Sequence $E$ and may have removed R20 in the east, thus the upper boundary of Sequence $E$ is called R20 $=R 30=R 40$ (Plate 1, Crose-section A). The fourth erosional event corresponds to the erosional surface at the base of Sequence A. The base of Sequence A (R50) is most extensive in eastern Harrison Bay. Sequence $E$ is truncated just seaward of Spy Island by R50 (Figure 5-3 and Plate 2, Cross-section C). Sequence $E$ is exposed at the sea-floor or is mantled by a veneer $(<2 \mathrm{~m}$ ) of sediment where R20 and R50 truncate at the sea-floor (Figure 5-3).

A reflector (R20(?)) (Figure 5-3) may be the equivalent of R20, based on the stratigraphic position of R2O(?) and other queried reflectors, (R30(?) and R40(?)). Correlation between R20 and R20(?) is not possible because of a data gap.

Internal reflector configurations within Sequence $\mathbf{E}$ are generally discontinuous, high amplitude, and hummocky to wavy. These configurations are characteristic of fluvial depositional environments. Continuous wavy reflectors may correspond to channel cutting within Sequence E.

Several cut and fill channels are clustered in an area just seaward of Pingok Island 


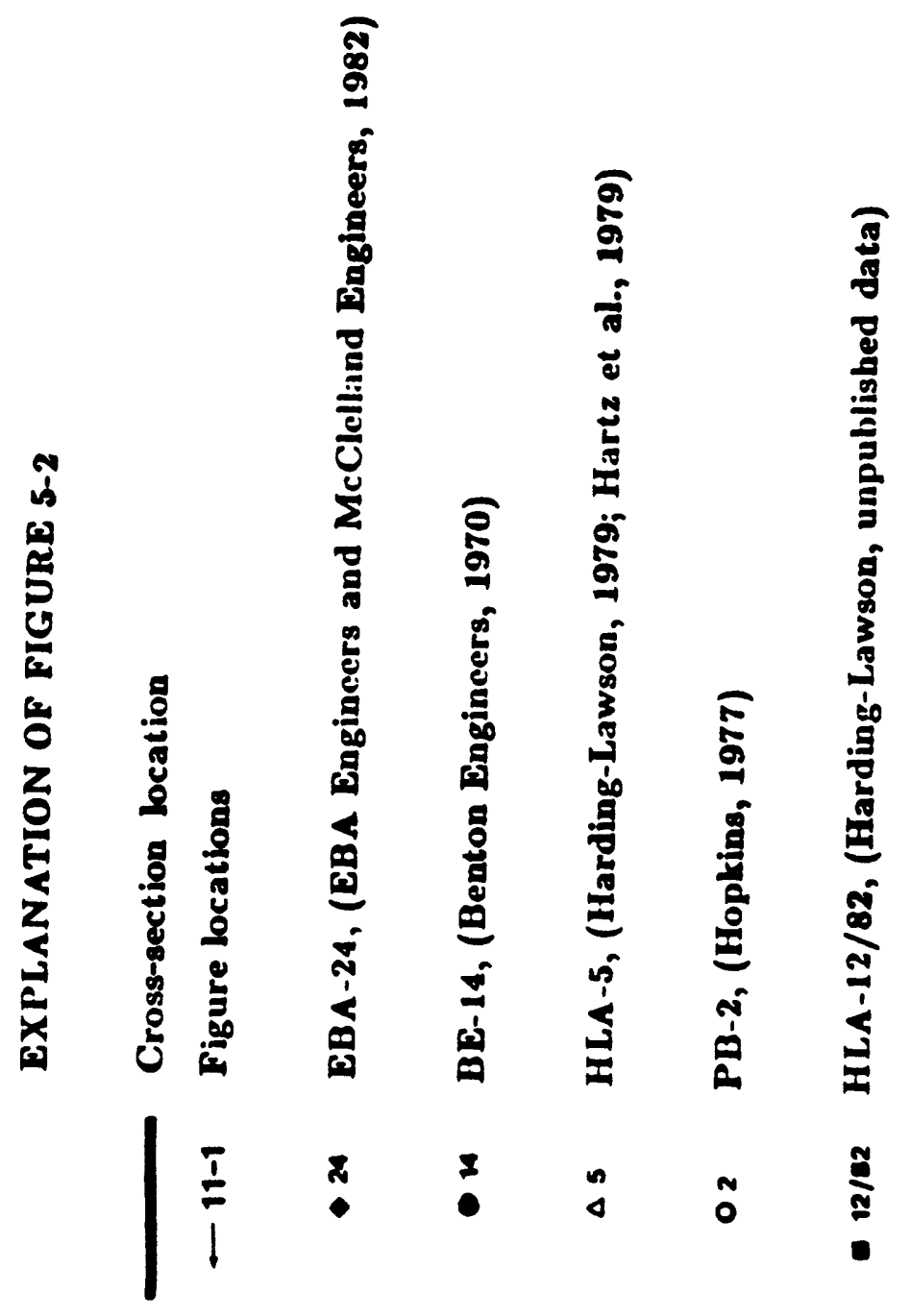

$31 a$ 


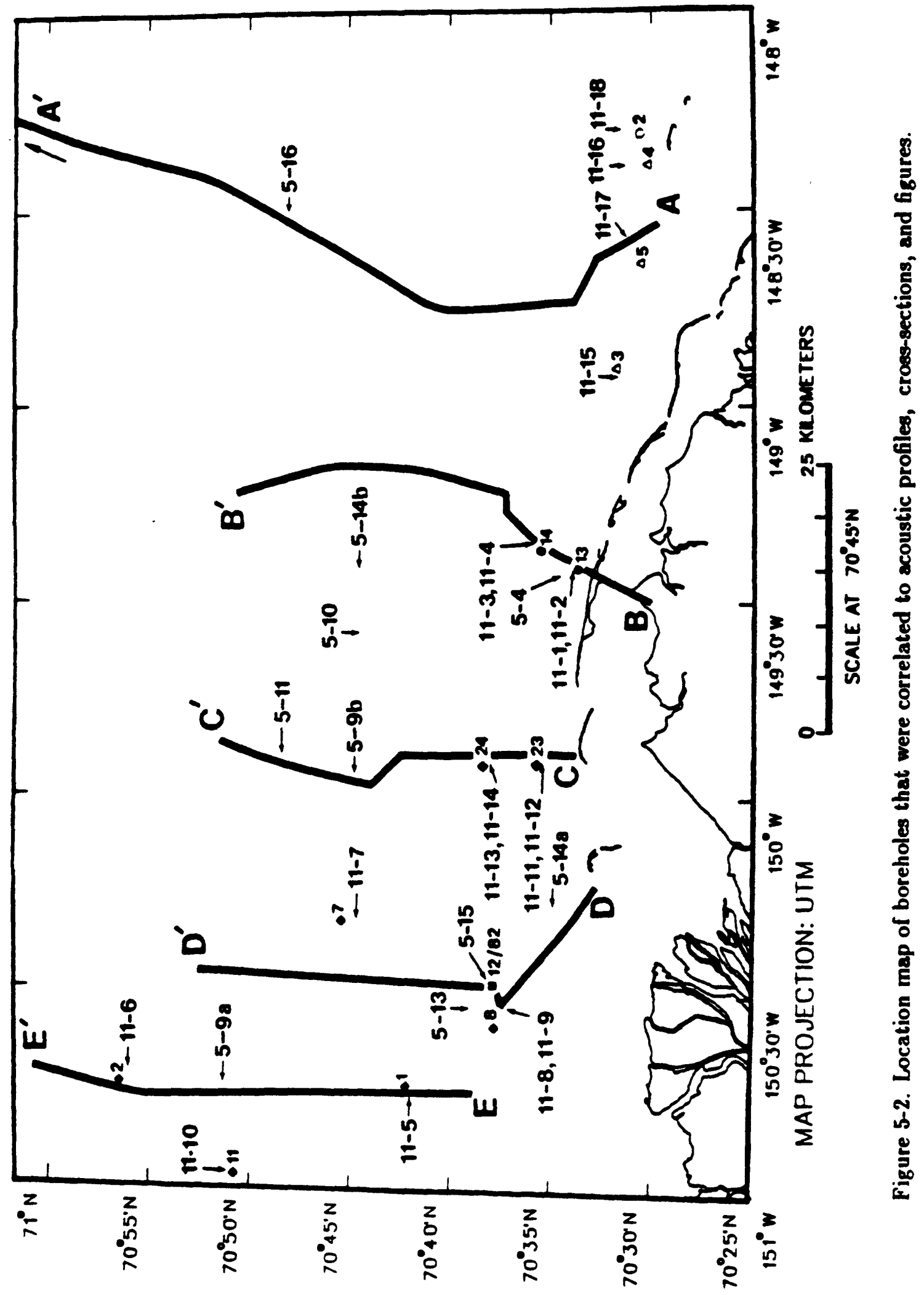




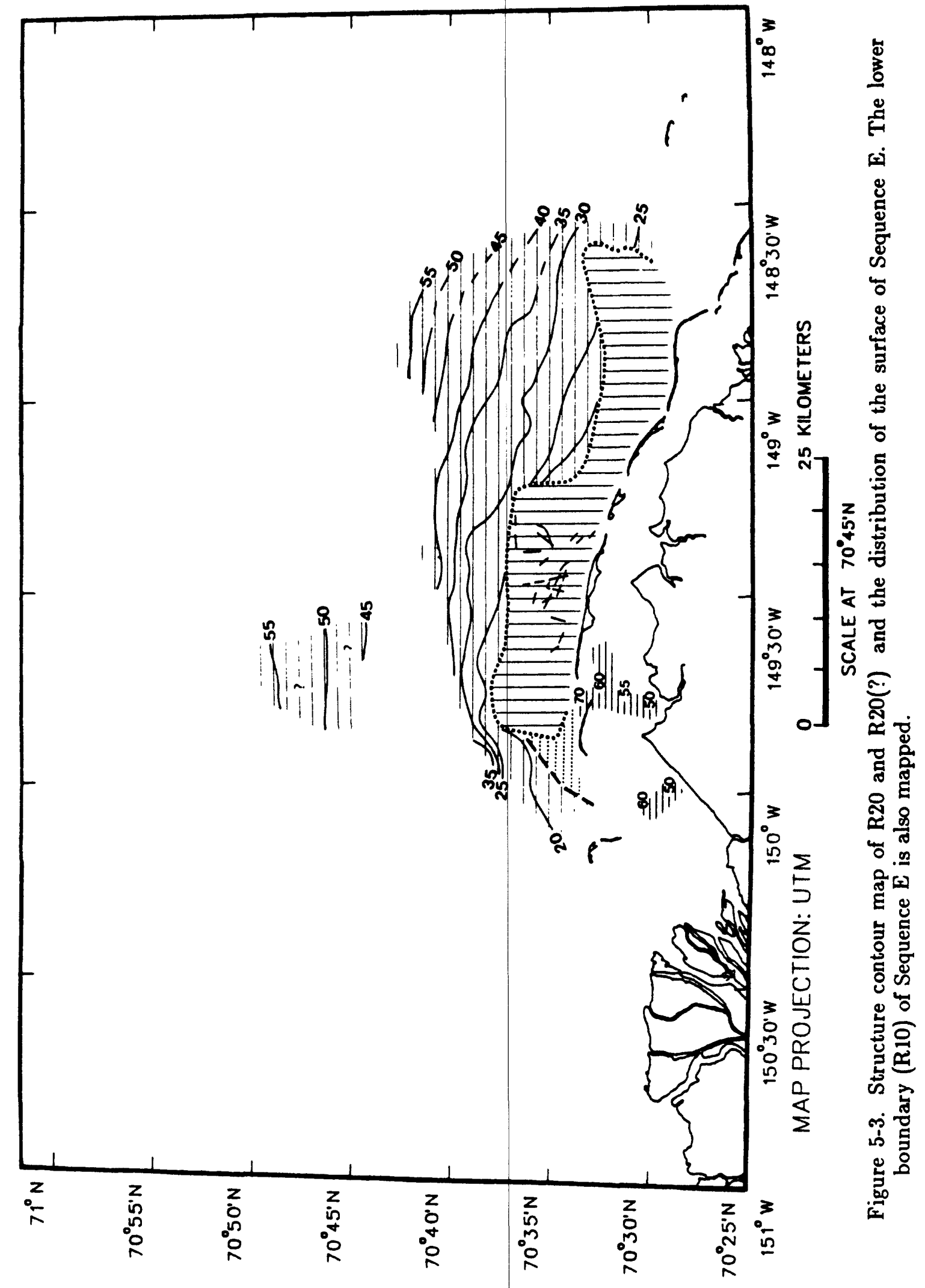




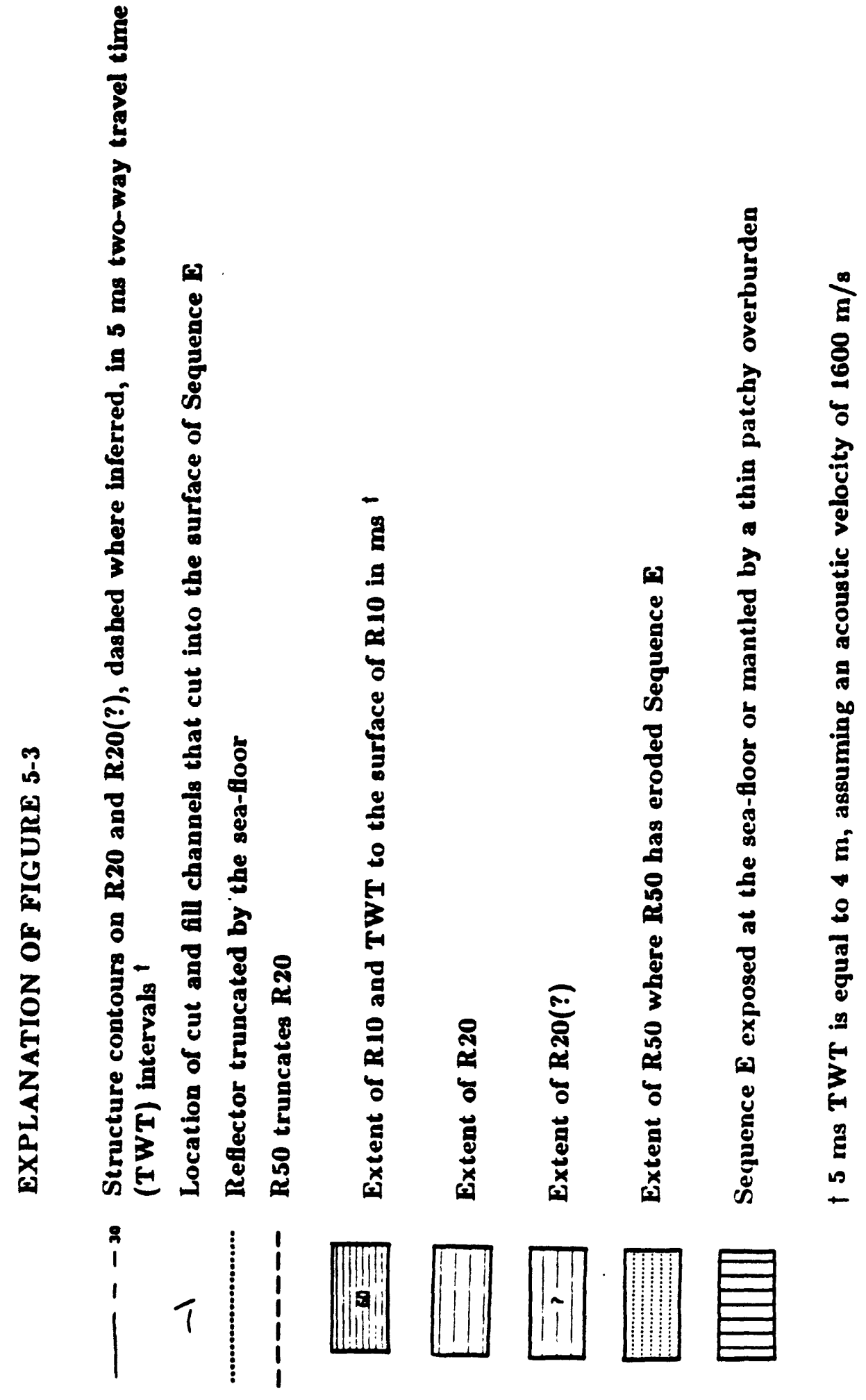

$33 a$ 
(Figure 5-3). The paleochannels are cut into the top of Sequence E to TWT's of 10 to $20 \mathrm{~ms}$ $(8$ to $16 \mathrm{~m})$. The paleochannels may have been cut and filled between any of three erosional events (R20, R30, or R40) that bevel Sequence E, because R20 $=R 30=R 40$ truncates the tops of cut and fill channels along the seaward edge of Sequence $E$. Based on the above, the paleochannels could have been filled near the end of Sequence $E$ deposition but not after the deposition of Sequence B. The apparent widths (1 to $2 \mathrm{~km}$ ) of paleochannels may be wider than true widths, because ship tracklines are likely to be oblique to the buried channels. Oblique crossings indicate the apparent dip of the channel fill foresets and channel walls. The paleochannels usually appear as asymmetric troughs that are filled with prograding deposits (Figure 5-4). A few of the paleochannels exhibit more complex fill. Several interpretations of the origin and depositional environment of the paleochannels are possible.

1) Prograding sigmoid shaped foresets within the channels represent lateral accretion surfaces of point bar deposits. Channel fill deposits prograde toward the steeper cut bank side of the channel wall (Figure 5-4). The inferred point bar deposits often prograde in a southeast direction. This suggests that the channel system migrated to the southeast. Generally, point bar deposits are expected to be about $3 \mathrm{~m}$ thick (Walker and Cant, 1984); however, a maximum thickness of $11 \mathrm{~m}$ is cited by Nijman and Puigdefabregas (1978). The inferred point bar deposits that fill the paleochannels in the surface of Sequence $E$ are 5 to $10 \mathrm{~m}$ thick.

2) Prograding channel fill may represent meandering tidal channel deposits. The apparent widths (about $1 \mathrm{~km}$ ) of the channels are considered too wide to be tidal channels. Also, the present Beaufort Sea has a microtidal range that inhibits formation of large tidal channels (Hayes, 1979).

3) Migrating tidal inlets of a barrier island system could have formed the cut and fill channels. Migrating inlets could have formed lateral accretion surfaces as the barrier island prograded into and filled the inlet channel.

4) Several small prograding deltas, perhaps flood-tidal deltas, migrated southeast and filled channel cuts with prograding deposits as sea-level transgressed Sequence E. Large tidal deltas are not presently extensive on the microtidal Beaufort shelf (Hayes, 1979).

5) Complex channel fill (Figures 11-3 and 11-4) represents deposition of channel bars from a braided fluvial system.

Knowledge of the paleodrainage source and direction would be useful to interpret the depositional environment of the cut and fill channels. The paleochannels could not be connected with any modern river system on the coastal plain. A single acoustic profile (Line 16-72) in Simpson Lagoon does not indicate any distinct cut and fill channels in the lagoon sub-bottom. However, the quality of this particular profile is degraded by seafloor multiples; therefore, the presence of cut and fill channels within the Simpson Lagoon sub-bottom was not ruled out. The extension of the paleochannels in a seaward direction could not be determined, because the channels and part of Sequence $\mathbf{E}$ have been removed by erosional events.

Based on borehole logs, Sequence $E$ consists of sandy gravel and gravelly sand. R20, the oldest upper sequence boundary of Sequence $E$, is penetrated by borehole HLA-5. A gravel over sandy gravel interface is logged at the depth of R20 (Figure 11-17). Elsewhere, the surface of Sequence $\mathrm{E}$ is truncated by the sea-floor or younger erosional events. In boreholes BE-13 (Figures 11-1 and 11-2), BE-14 (Figures 11-3 and 11-4), EBA-23 (Figures 11-11 and 11-12), and HLA-3 (Figure 11-15) a reflector is observed where a thin 


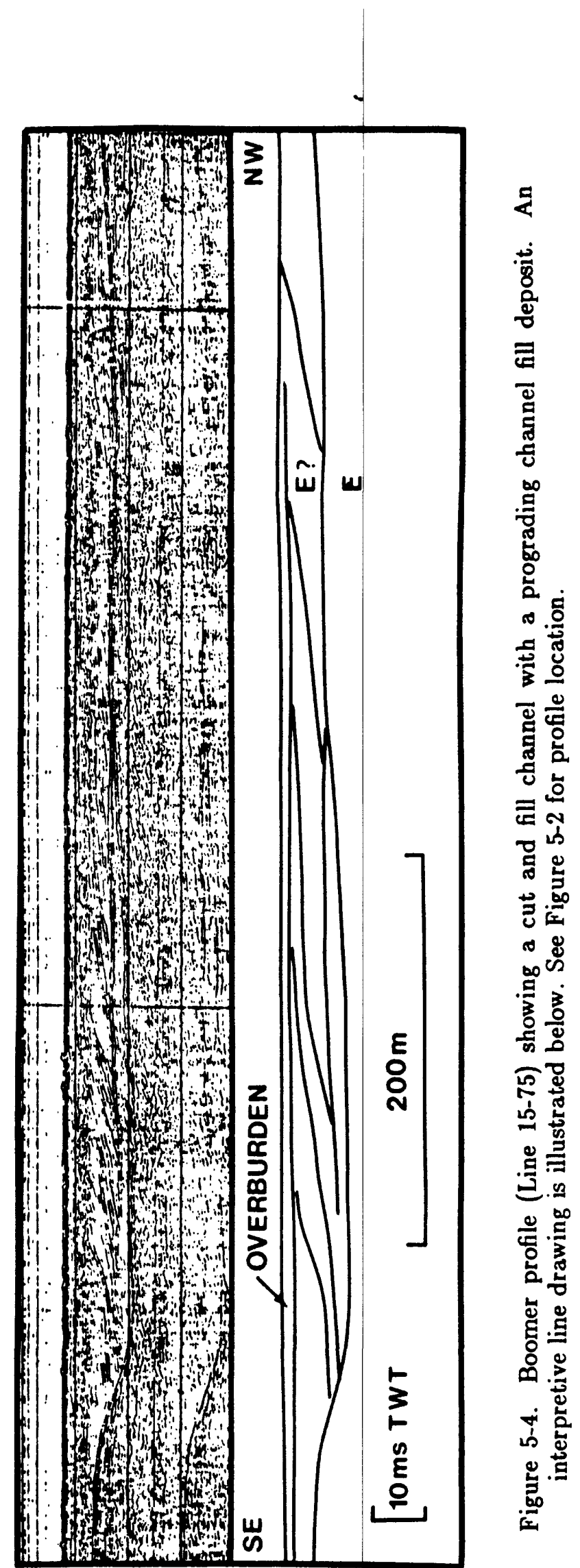


overburden of silt and clay contact and and gravel of Sequence $\mathbf{E}$. Several boreholes within Simpson Lagoon, Gwydyr Bay, and two boreholes outside the Return Lolands are not correlated to acoustic profiles. These boreholes show fine sand, silt, and clay deposited over a thick unit of and and gravel. The sand and gravel unit preaumbily correlates to Sequence $\mathbf{E}$. The depth to the gravel contact, top of Sequence $\mathbf{E}$, is mapped along with the overburden thickness (Figure 5-5). The overburden is thicker (5 to $9 \mathrm{~m}$ ) within the lagoon. Boreholes seaward of the barrier islands have thin overburdens $(<2 \mathrm{~m})$. The base of Sequence $\mathbf{E}$ is not evident in the borehole logs, suggesting that Sequence $\mathbf{E}$ is a thick unit. Borehole HLA-5 shows that deposits of mostly and and gravel extend to a depth of $91 \mathrm{~m}$ which is deeper than the penetration depth of the boomer profiles in this region.

Borehole BE-14 penetrates one paleochannel that cuts into the upper surface of Sequence E (Figures 11-3 and 11-4). The channel fill deposit consiats of coarse andy gravel, and the base of the channel is marked by a thin lens of organic and. This borehole confirms the coarse grained channel fill that is expected to be associated with complex fill in the acoustic profiles. Cut and fill channels with complex fill are interpreted as braided Guvial deposits.

Acoustic stratigraphic interpretations indicate that Sequence $\mathbf{E}$ is primarily a nonmerine fluvial deposit. Thick sand and gravel in the boreholes oupport the acoustic interpretation. Sequence $\mathrm{E}$ may be part of a prograding alluvial fan that extends from the present cosstal plain on to the present inner shelf; deposition on the inner shelf probably occurred during lowered sea-level and subaerial exposure of the shelf. Cut and fill channels may have formed near the end of Sequence $\mathbf{E}$ deposition, although the paleochannels may have been cut and filled between any of the erosional events (R20, R30, or R40) that followed Sequence $\mathrm{E}$ deposition. The buried channels may have been part of a large meandering river system. Such a fluvial system differs from braided rivers on the present cosstal plain, such as the Kuparuk and Sagavanirktok Rivers. A fluvial system that is dominated by meandering like the Colville River and Colville River Delta would produce paleochannels with prograding fill. Ground truth information, such as lithologic and paleontologic studies, are needed to determine the depositional environment and source of the paleochannels. After the deposition of Sequence $\mathbf{E}$, sea-level transgreased and beveled Sequence $\mathbf{E}$ and the paleochannels. This unconformity is observed in the acoustic profiles as R20. A maximum age of $1.8 \mathrm{Ma}$ and a minimum age of Middle Pleistocene is suggested for Sequence $\mathrm{E}$ in Section 6.4 of this thesis.

\section{Acontic Sequence D}

Sequence D lies between R20 and R30 or R30=R40 (Plates 1 and 2, Cross-sections $A$ and $B$ ). R20 defines the lower sequence boundary. The upper sequence boundary is defined by $R 30$ or R30=R40. Based on the sequence boundary definitions, Sequence $D$ is present in the eastern part of the study area and is questionable in the weat. The thickness of Sequence D is not well defined, because the lower boundary (R20) does not extend far seaward beneath the upper sequence boundaries. Based on the landward thinning and onlapping character of Sequence $\mathrm{D}$, the deposit appears to thicken from $0 \mathrm{~m}$ on the inner shelf to thicker deposits on the middle and outer shelf.

A structure contour map indicates the TWT to the top of Sequence D and illustrates the geographic extent of Sequence D (Figure 5-6). Sequence D onlaps Sequence $E$ where R30=R40 onlaps R20. R30 dips to the northeast and extends to the middle shelf as observed on a single line (Line 751-77) that is perpendicular to the cosst (Plate 1, Crosssection $\mathbf{A}$ ). 


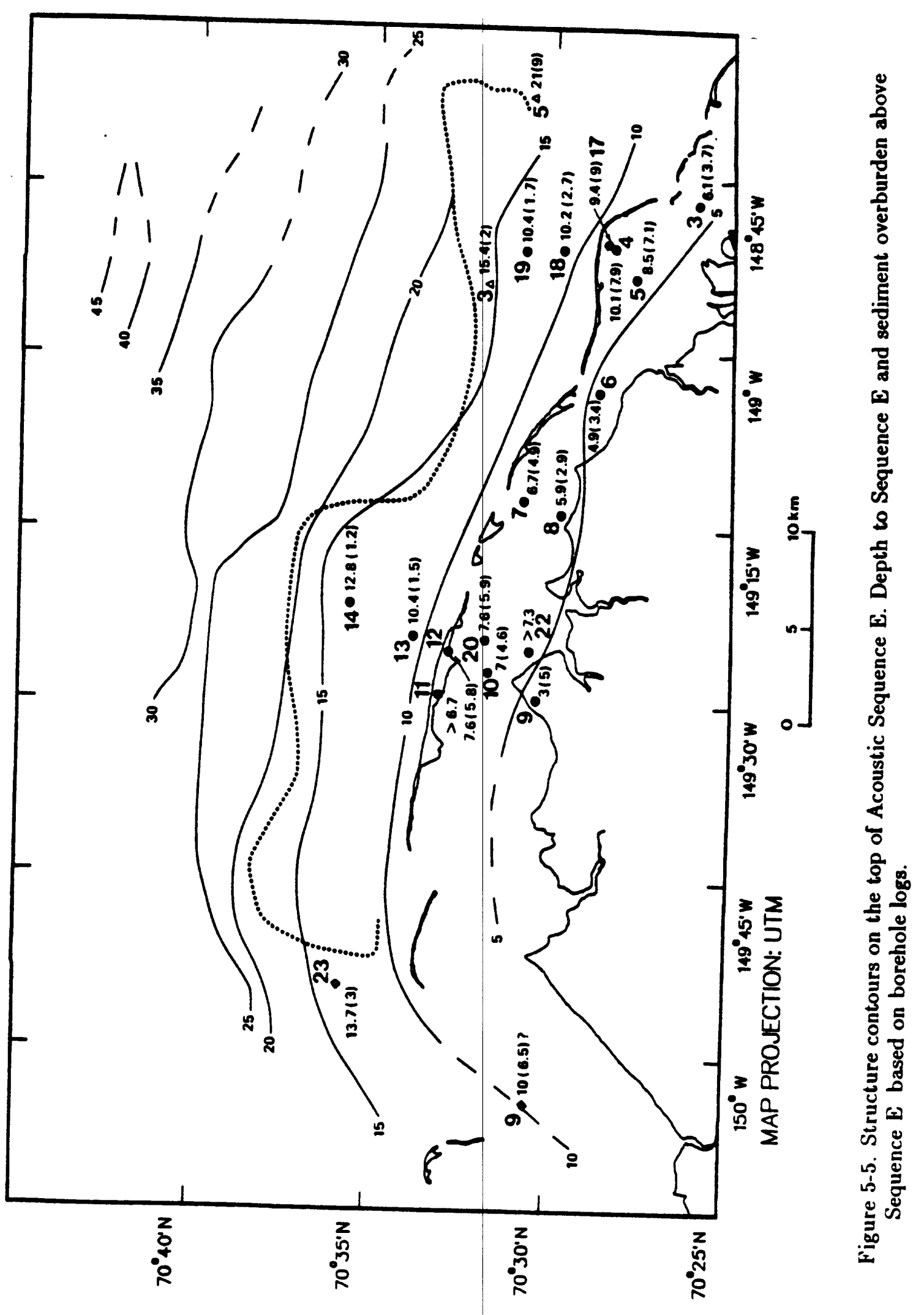




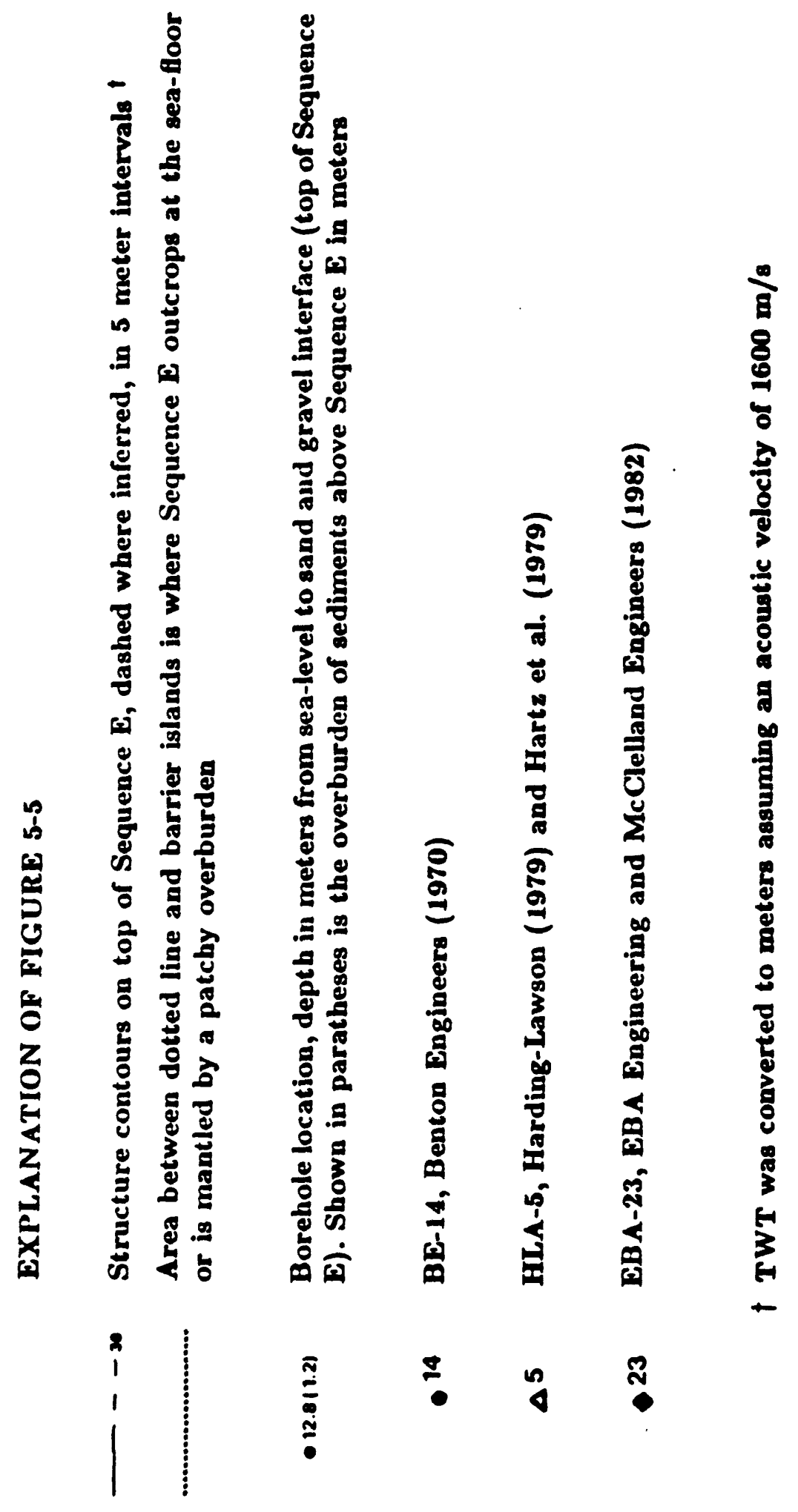

$37 a$ 


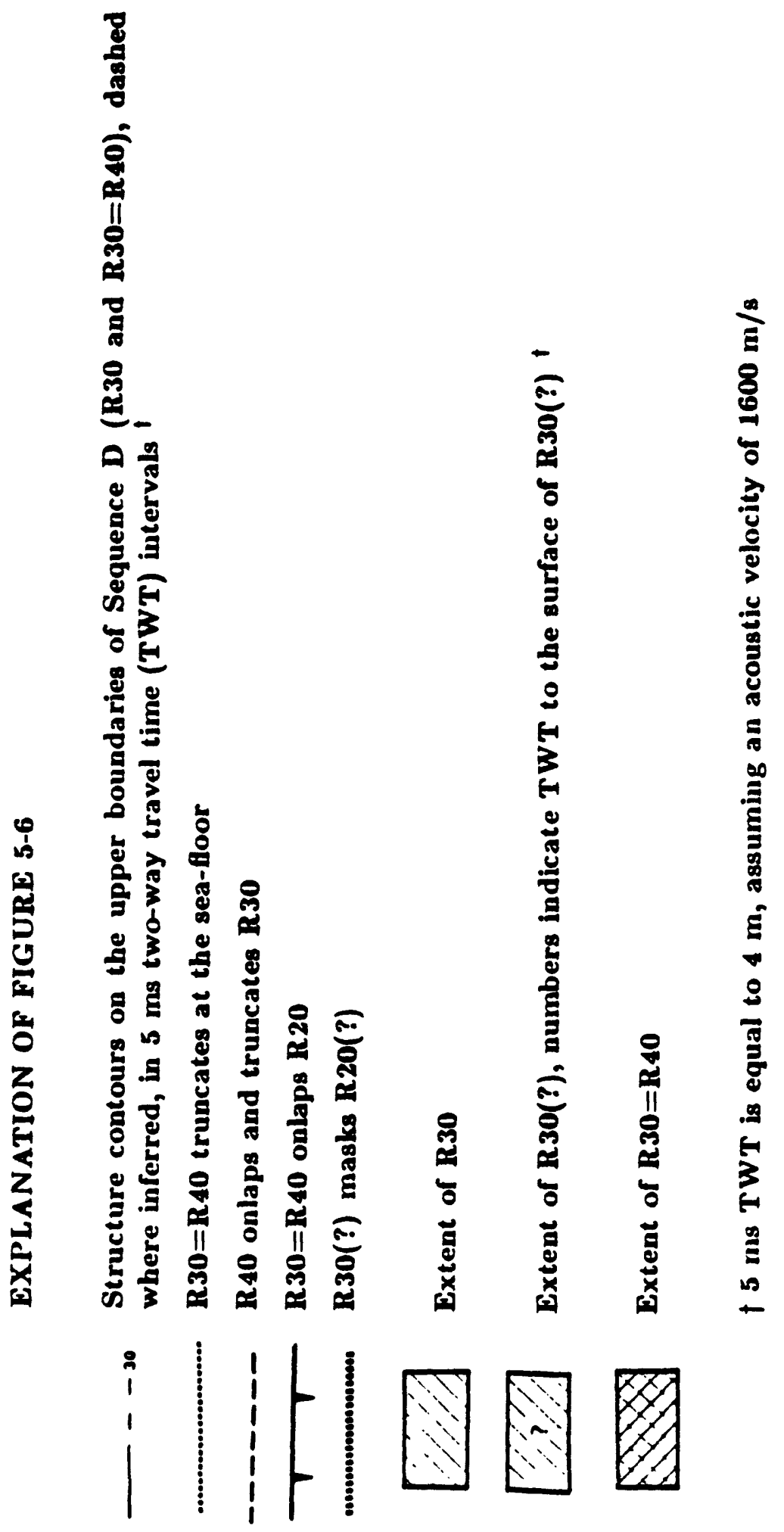




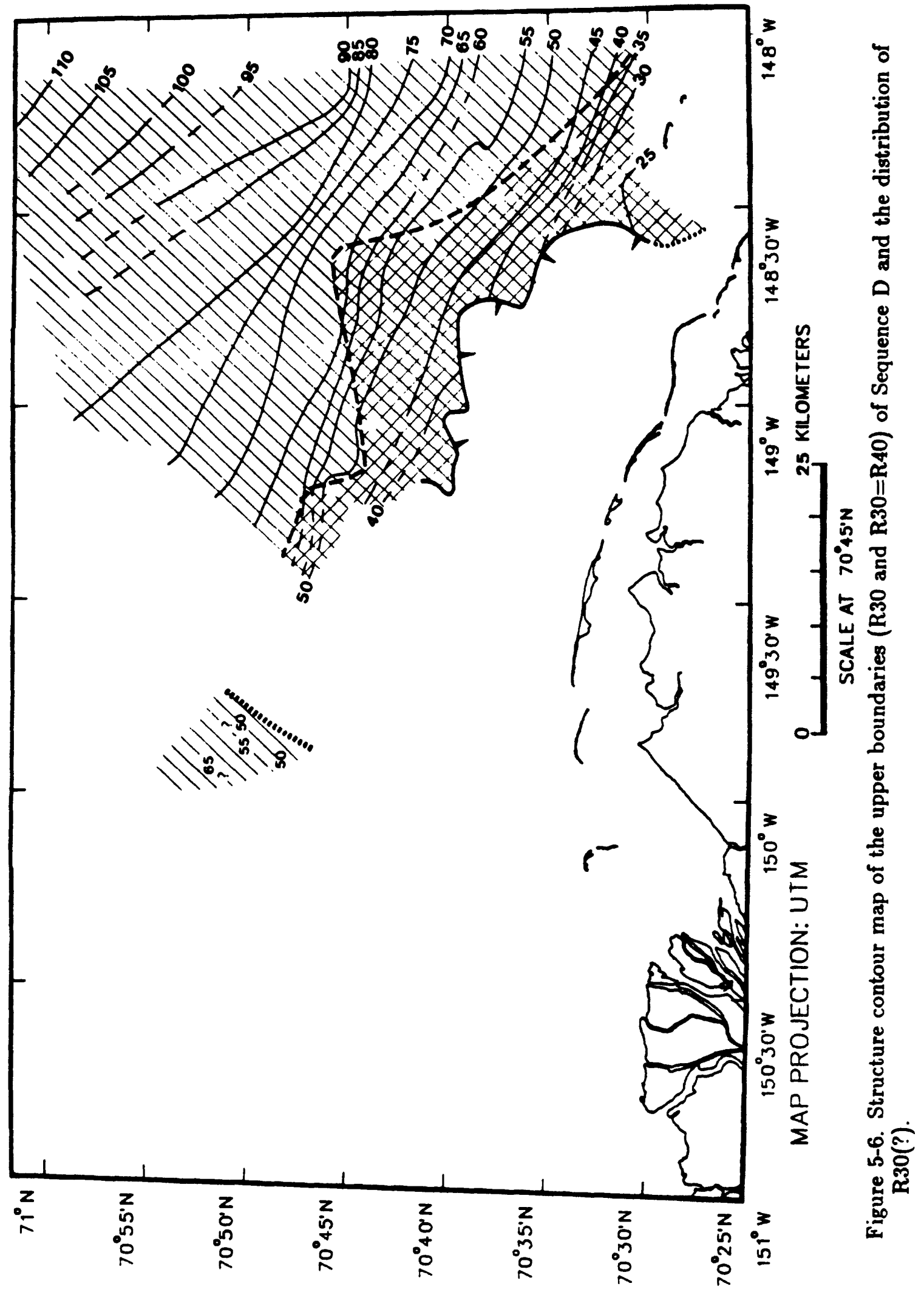


A reflector, $\mathrm{R30}(?)$, to the west may correlate with $\mathrm{R} 30$ based on the stratigraphic positions of the reflectors in the area. R30(?) could not be tied to R30 with the present data set, thus R30(?) is queried. R30(?) is masked by shallower reflectors to the west and south.

Internal reflectors of Sequence D are moderately continuous and have low amplitudes. This acoustic character gives the sequence a transparent appearance. Based on the above characters, Sequence $\mathrm{D}$ is a homogeneous deposit with a common depositional origin. No distinct cut and fill channels are observed within Sequence D.

Two boreholes, PB-2 and HLA-4, penetrate Sequence D north of Reindeer Island. The upper boundary of Sequence $D, R 30=R 40$, corresponds to a distinct lithologic contact of gravelly mud over gravel in borehole PB-2 (Figure 11-18). In borehole HLA-4 clayey silt overlies gravelly sand of Sequence $D$. Sequence D onlaps Sequence $E$ and may be thin. The gravelly lithology of Sequence $D$, below the $R 30=R 40$ interface, may not be representative of the sequence. Sequence D lithology further offshore, as the acoustic profiles indicate, may be a fine grained marine transgressive deposit. Boreholes are not available to confirm this interpretation. Ice-bonded gravelly sand is logged below the R30=R40 interface in borehole HLA-4, thus the contact between non-bonded clayey silt and ice-bonded gravelly sand appears to enhance $\mathrm{R30}=\mathrm{R} 40$ at the lithologic contact. This may contribute to the irregular nature of $\mathrm{R30}=\mathrm{R} 40$ at this location (Figure 11-16).

Sequence D was deposited as sea-level transgressed Sequence E. R20 is the basal transgreasive surface of Sequence $D$. The homogeneous character of Sequence $D$ on the scoustic records, and the lack of cut and fill structures suggests this deposit is mostly fine grained marine. Also, Sequence D clearly onlaps Sequence E as would be expected of a marine transgressive sequence. Any nonmarine sediments deposited near the end of Sequence $D$ deposition may have been removed during following sea-level transgressions. The gravel in the boreholes that correlated to Sequence $D$, where Sequence $D$ is thin and onlaps Sequence $\mathbf{E}$, may be transgressive beach deposits. A Middle Pleistocene age is suggested for Sequence D in Section 6.4 of this thesis.

\section{Acoustic Sequence C}

Sequence $C$ is bounded by two unconformities, R30 and R40 (Plates 1 and 2, Crosesections $A$ and $B$ ). R30 is the lower sequence boundary, and R40 defines the upper surface. Again, R30 and R40 are defined in the eastern part of the study area and are queried in the west. Sequence $C$ thickens in a seaward direction from $0 \mathrm{~m}$ on the inner shelf to $12 \mathrm{~m}$ on the middle shelf and thins again to $0 \mathrm{~m}$ on the outer shelf (Plate 1, Crose-section A).

A structure contour map of R40 shows the aerial distribution of Sequence C (Figure 5-7). Sequence $C$ onlaps Sequence $D$ in a landward direction where R30 and R40 converges $(R 30=R 40)$. R40 appears to downlap in a seaward direction on to R30 on one acoustic profile (Line 751) that extends to the outer shelf; therefore, Sequence $C$ thins in a seaward as well as a landward direction.

A reflector (R40(?)) in the western part of the study area possibly correlates with $R 40$ based on the stratigraphic position of R40(?). The structure contour of R40(?) (Figure 5-7) indicates a basin structure. Contours show that R40(?) dips seaward and further weat dips to the southeast. R40(?) is masked by shallower rough bummocky reflectors in Harrison Bay and appears to extend beneath the rough hummocky reflectors into the subsurface of Harrison Bay. This acoustic anomaly that masks deeper reflectors is mapped as the Acoustic Transmission Boundary (ATB) in Harrison Bay (Figure 5-7). 


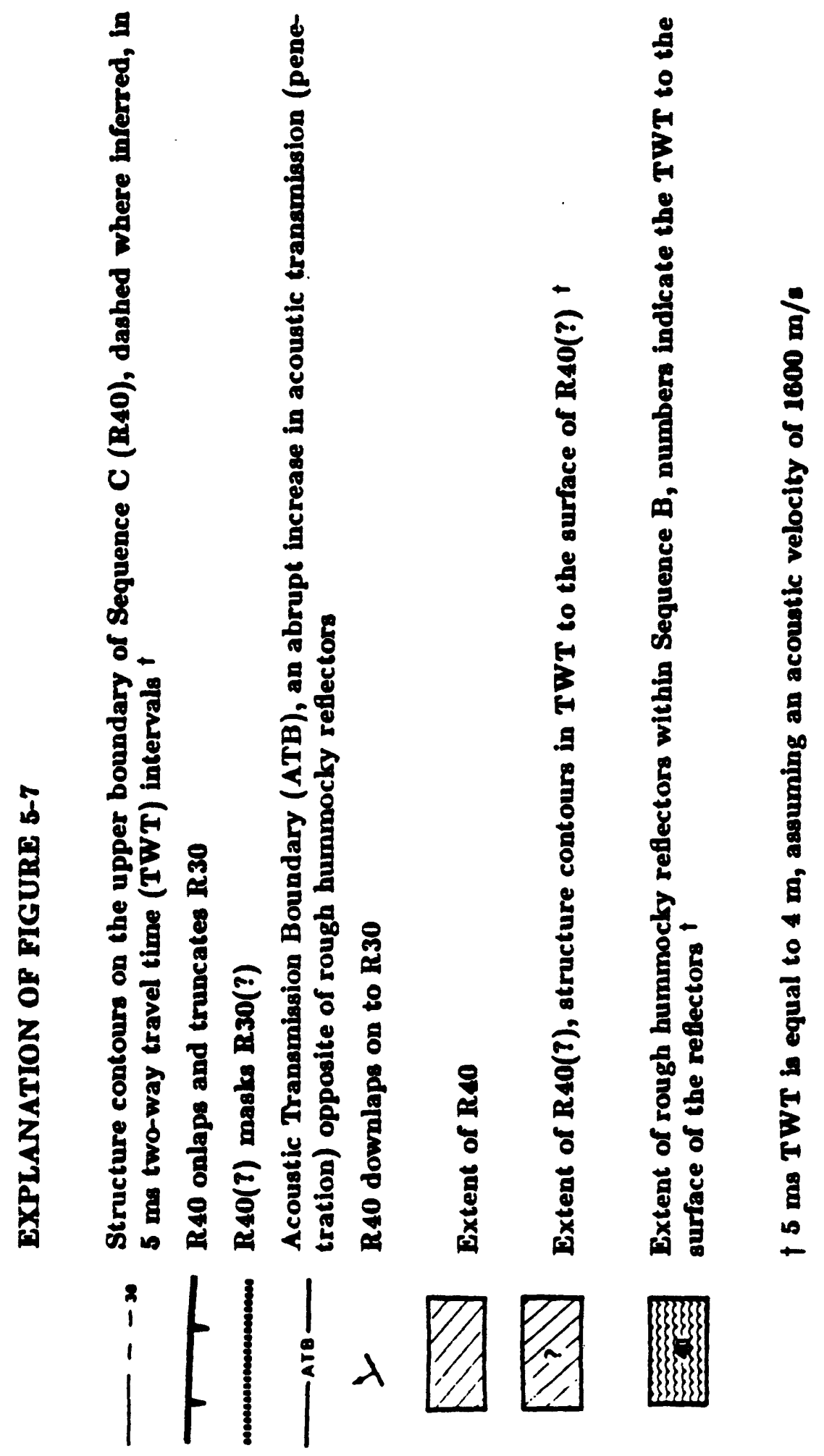

$39 a$ 


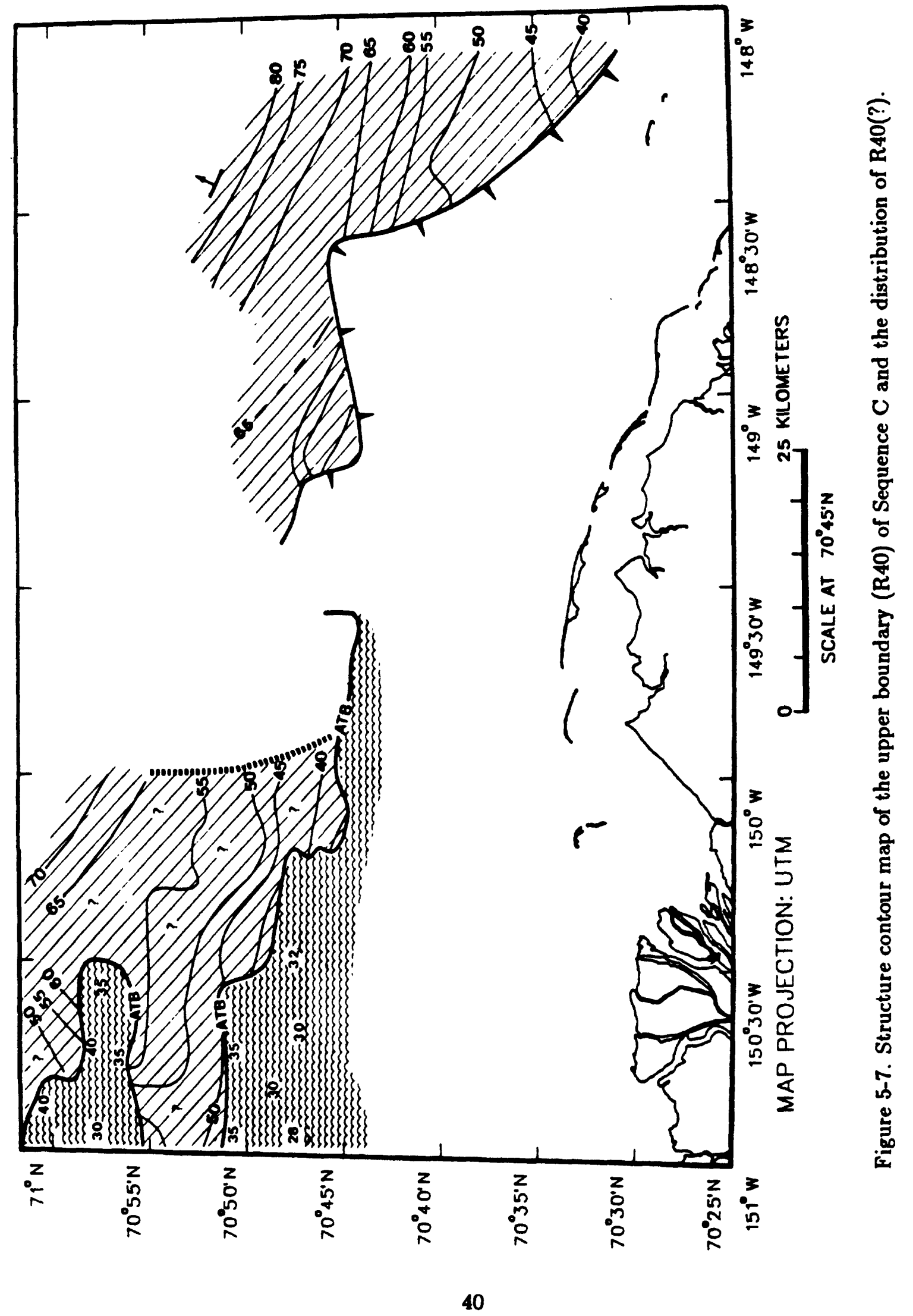


Sequence $\mathbf{C}$ is similar in acoustical character to Sequence D. Internal reflectors are generally weak and moderately continuous or transparent. Sequence $\mathbf{C}$ also lacks cut and fill channels.

Similar to Sequence $D$, Sequence $C$ is interpreted as a transgressive marine depooit. Boreholes are unavailable to confirm this interpretation. Sequence $\mathbf{C}$ sediments onlapped Sequence D during a rise in sea-level. The basal transgressive surface is represented by R30 in the acoustic profiles. Nonmarine deposits of Sequence $\mathbf{C}$ may have been removed during the next transgression. This next sea-level rise beveled the surface of Sequence $C$, part of Sequence D, and Sequence E. R40 is this basal transgressive surface, and R30=R40 is where the transgreasion cut into R30 and Sequence $D$. This same transgreasion may have also cut into R20 and Sequence E. A Middle Pleistocene age and a tentative correlation to the Wainwrightian transgression on the coastal plain is suggested in Section 6.4 of this thesis.

\section{Acoustic Sequence B}

The lower boundary of Sequence $B$ is defined by R20, R30, R40, and R30 $=R 40$ in the east (Plates 1 and 2, Cross-sections A and B). R20, R20(?), R30(?), or R40(?) defines the lower sequence boundary in the western part of the study area (Plates 2 and 3, Crose-sections C, D, and E). The lower boundary of Sequence B is complicated because of the onlapping structure of the unconformities. The upper boundary of Sequence $B$ is defined by a continuous reflector (R50) that is extensive in eastern Harrison Bay, under Stamukhi Shoal, and north of Prudhoe Bay (Plates 1 through 3, Cross-sections A through $E)$. Elsewhere, the surface of Sequence $B$ is exposed at the sea-floor. Sequence $B$ is extensive over most of the shelf. The sequence's thickness ranges from $0 \mathrm{~m}$ thick on the inner shelf to about $25 \mathrm{~m}$ thick on the middle shelf and possibly $>25 \mathrm{~m}$ thick on the outer shelf. Instead of mapping the distribution of the upper boundary of Sequence B, features that occur within Sequence B are mapped in Figure 5-8.

Rough hummocky reflectors form a horizon within Sequence B. Rough hummocky reflectors that are widespread in Harricon Bay terminate along a margin I called the ATB. The ATB is mapped where transmission of the acoustic signal abruptly increases and rough hummocky reflectors terminate. Rough hummocky reflectors on one side of the ATB appear to inhibit penetration of the acoustic signal into the sub-bottom. The increase in acoustical penetration opposite of the rough hummocky reflector horizon is marked by the appearance of deeper refiectors that include R20(?), R30(?), and R40(?). These queried reflectors appear to extend beneath the rough hummocky reflectors in Harrison Bay until they are totally masked. The ATB may be sharp (Figure 5-9a) or appear as a transitional zone of "jumpy" reflectors (Figure 5-9b). Rough hummocky reflectors are also found within Sequence $B$ to the east but do not mask deeper refiectors as in Harrison Bay; the rough reflectors to the east may not correlate to those in Harrison Bay.

A reflector (R48) within Sequence B is partially masked by R50 in an area north of the Colville River Delta (Figure 5-8). R48 dips landward and truncates at the sea-floor along the seaward edge of the reflector. R48 may be extensive beneath R50 but is only seen on the acoustic profiles where R50 is discontinuous or nonexistent.

Two types of cut and fill channels incise the surface of Sequence B. Asymmetric paleochannels with complex fill are one type of buried channel located in eastern Harrison Bay and north of Reindeer Island (Figure 5-8). A cut and fill channel is well defined on a boomer profile but is poorly defined on $3.5 \mathrm{kHz}$ profiles in Harrison Bay. A paleodrainage pattern is inferred for asymmetric channels in Harrison Bay. The asymmetric channels 


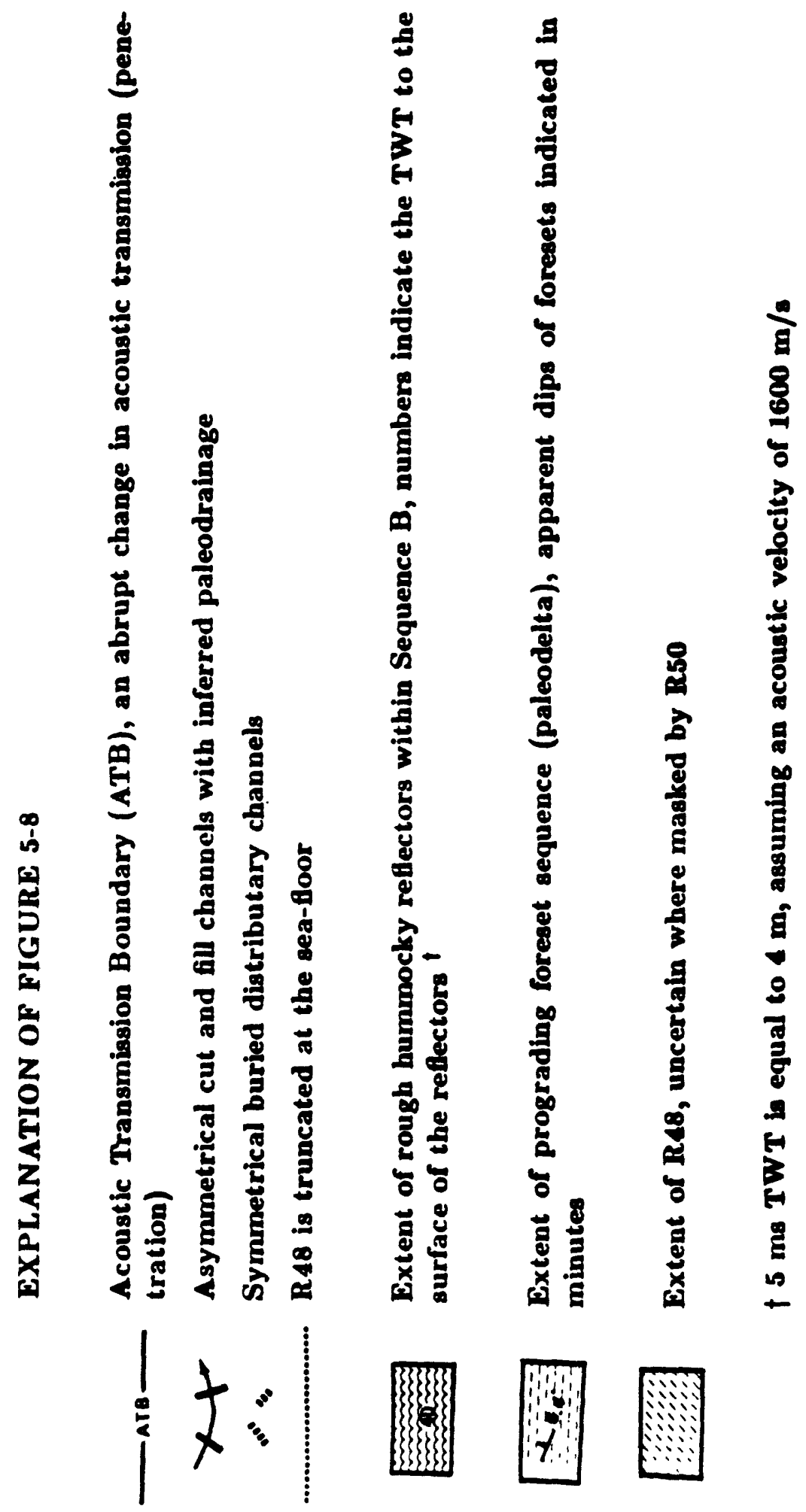

$41 a$ 


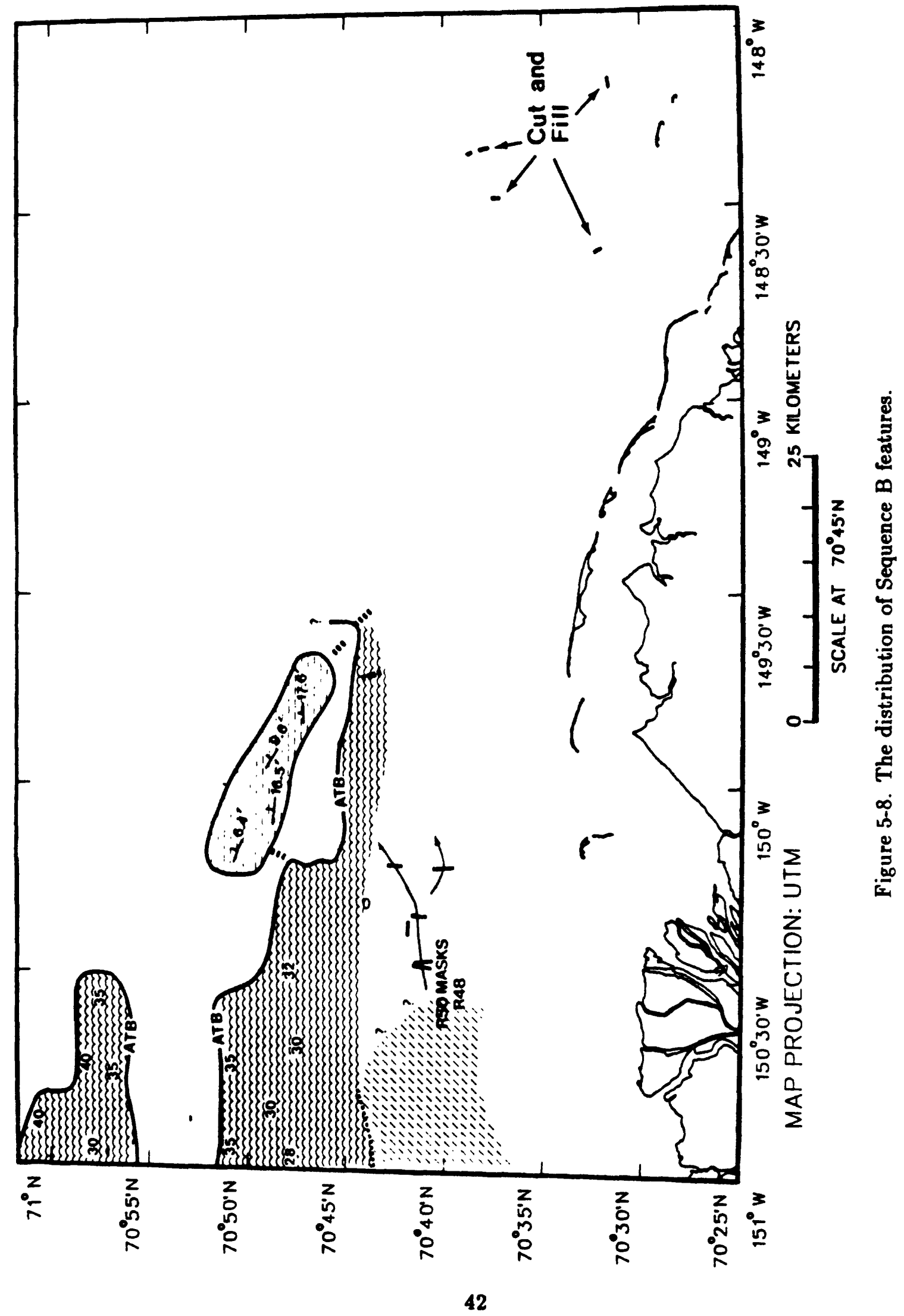



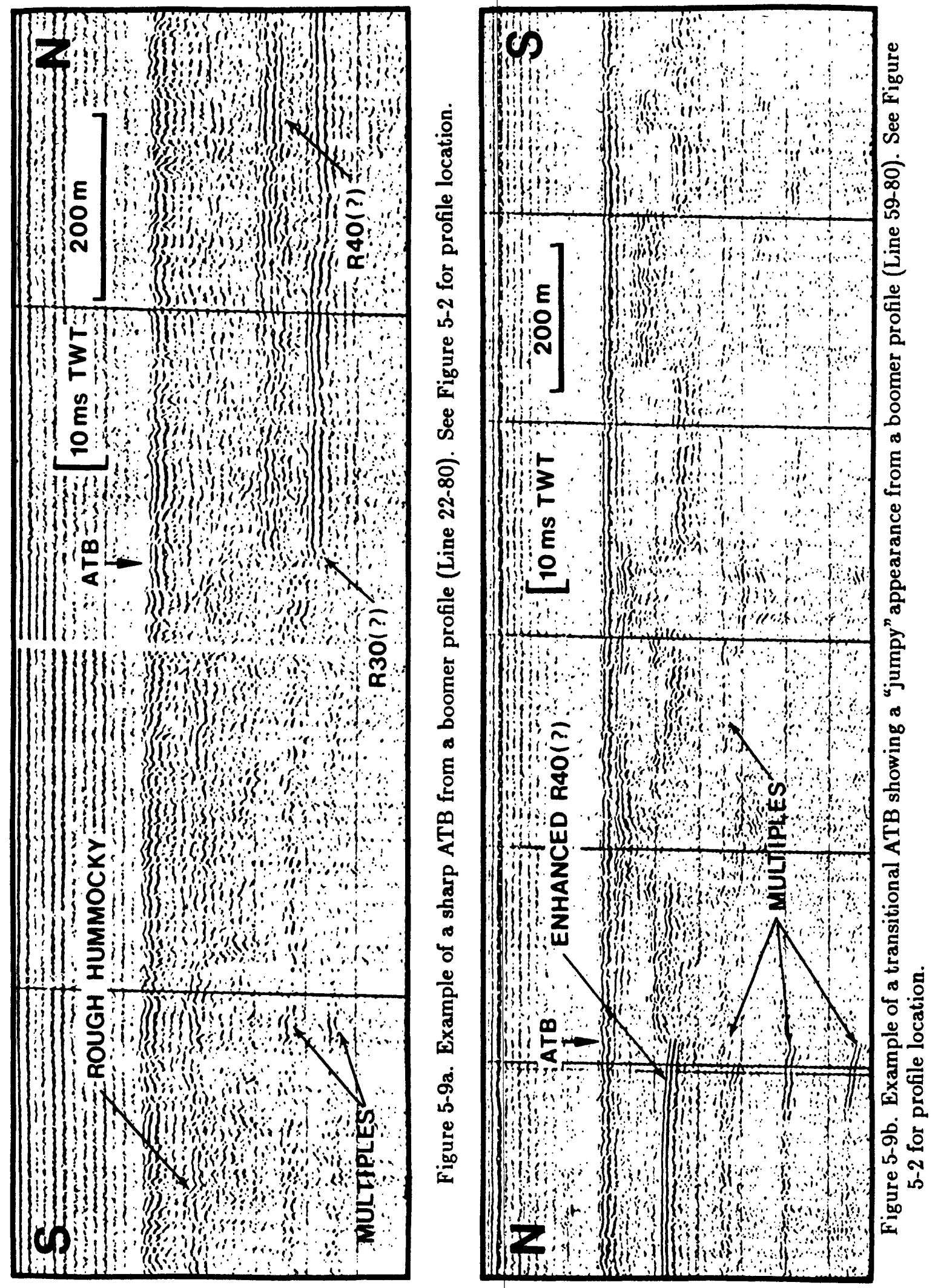
are interpreted as fluvial features. Several symmetrical paleochannels (Figure 5-10) are mapped west of Stamukhi Shoal (Figure 5-8). Symmetrical channels are interpreted as buried distributary channels.

Seaward of the buried distributary channels, a package of prograding oblique reflectors is observed within Sequence B (Figure 5-11). Prograding reflectors dip seaward and downlap on to R40(?), R30(?), or R20(?). The prograding reflectors truncate at the seafloor, thus Sequence $B$ is exposed at the seabed. I interpreted this prograding sequence of reflectors as a prodelta sequence. Symmetrical cut and fill channels are part of the delta front (subaqueous) and delta plain (subaerial) deposits. It is not clear if fluvial cut and fill channels in Harrison Bay are connected to these deltaic deposits. The most likely source of the buried distributary channels and delta foresets is from the paleodrainage of the Colville River. The size of the buried delta is comparable to the modern Colville River Delta. The relatively greater dip, between $6^{\prime}\left(0.1^{\circ}\right)$ and $17^{\prime}\left(0.28^{\circ}\right)$, of the paleodelta foresets compared to the dip of the modern Colville Delta front (about $3^{\prime}$ or $0.05^{\circ}$ ) suggests that depositional conditions were different in the past. Perhaps a deeper paleobathymetry at the delta front and prodelta altered the sedimentary processes of the past. A relatively high fluvial sediment flux, compared to the present Colville River, may have provided conditions more favorable for the delta to form.

Several boreholes that penetrate Sequence $B$ on the inner shelf show that the sequence consists of silt, clay, pebbly mud, and in one borehole as beach gravel. Borehole HLA-5 penetrates Sequence B where R20 is the lower sequence boundary (Figure 11-17). R20 correlates to an interface between beach gravel of Sequence $B$ above and a glacial outwash gravel (Hartz et al., 1979) of Sequence E below. Two boreholes, HLA-4 and PB-2, show that the lower sequence boundary $(R 30=R 40)$ of Sequence $B$ correlates to a contact between silt and clay of Sequence $B$ over sand and gravel of Sequence D (Figures 11-16 and 11-18). Boreholes HLA-4 and PB-2 show 1.4 to $3 \mathrm{~m}$ of clean sand above silt, clay, and pebbly mud of Sequence B. The clean sand are from recent shoal construction as shoals are observed on the acoustic profile (Figure 11-16). These shoals may have originated as Reindeer Island migrated past the location. Sequence B outcrops at the sea-floor where boreholes EBA-2 and EBA-11 penetrate Sequence B (Figures 11-2 and 11-10). Both boreholes indicate clayey silt at the sea-floor. The beach gravel of Sequence $B$ encountered in borehole HLA-5 indicates a different depositional environment compared to other boreholes. The Sequence B that is correlated to borehole HLA-5 is part of a trough that thickens south towards Prudhoe Bay (Plate 1, Cross-section A). The interpretation of Sequence $B$ at this location is uncertain.

Some of the reflectors within Sequence $B$ appear to correlate to ice-bearing sediments. Boreholes EBA-2, EBA-7, and EBA-11 penetrate rough hummocky reflectors. The correlations indicate that lithologic contacts do not correspond with rough hummocky reflector horizons. Boreholes EBA-2 and EBA-7 contain a horizon of partially-bonded silty clay with 3 to $20 \mathrm{~mm}$ thick ice lenses that correlate to rough hummocky reflector horizon (Figures 11-6 and 11-7). However, an ice-bearing horizon is not observed in borehole EBA-11 where a rough hummocky reflector is observed on the acoustic profile (Figure 11-10). The depth at which the reflector occurs in borehole EBA-11 was not sampled according to the borehole log. Also, the ice-bearing horizon may not have been sampled because of the lateral discontinuity of the ice-bearing horizon. Partially-bonded silty clay containing vertical ice lenses are encountered in borehole EBA-24 (Figure 11-14). Discontinuous hummocky reflectors that are offset from the borehole may correlate to the partiallybonded horizon. An irregular reflector is expected to occur at these partially-bonded horizons, because varying acoustic impedances would be encountered over short distances. 


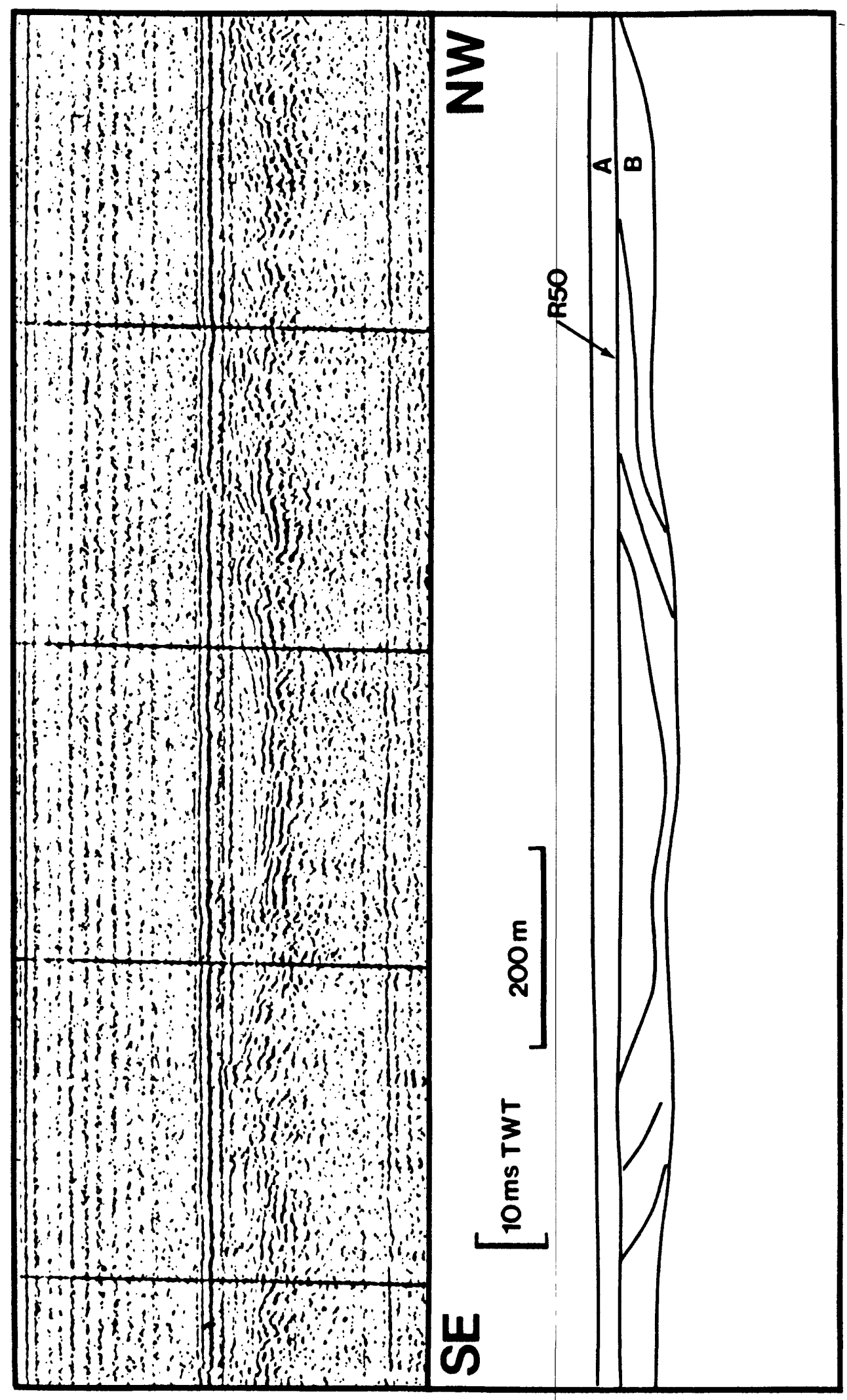

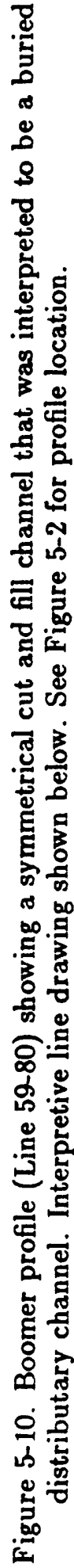




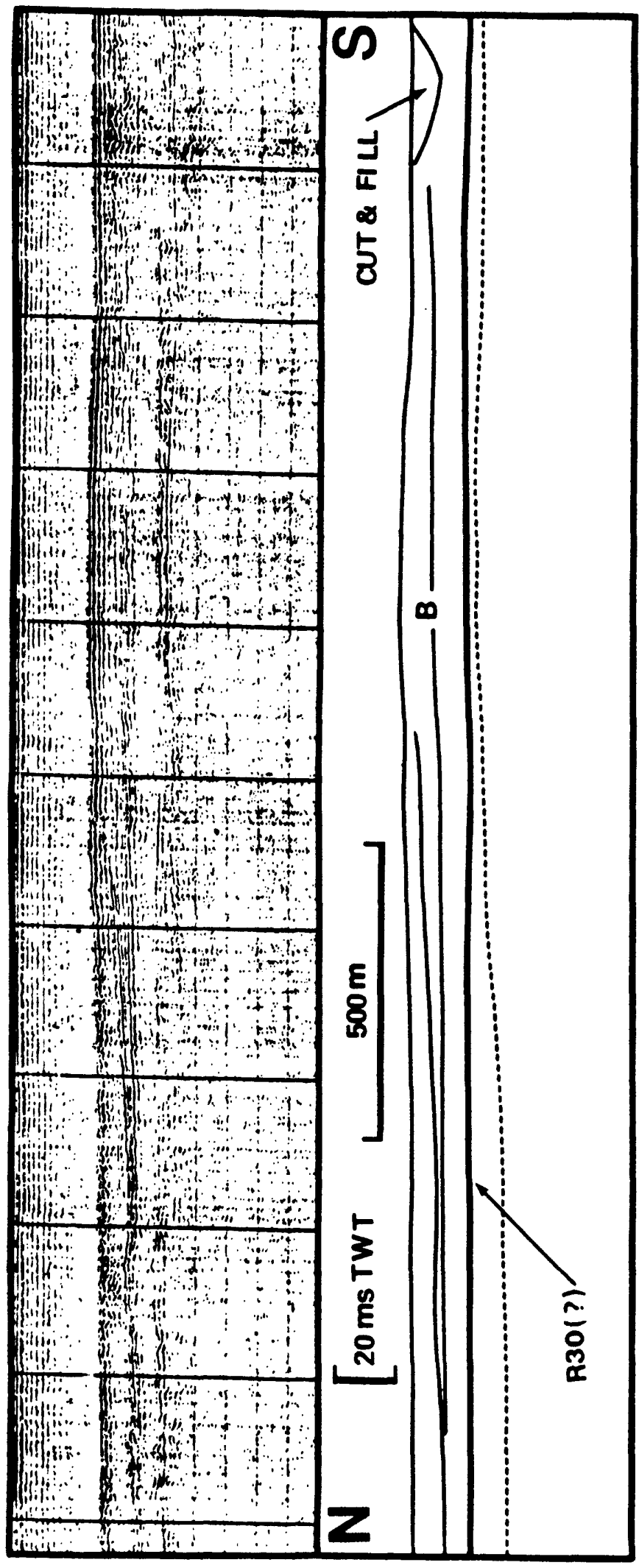

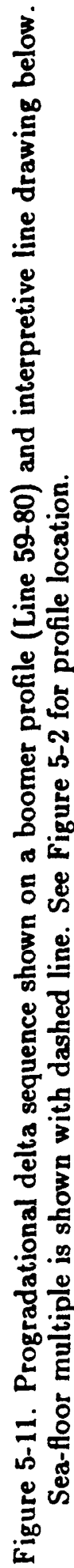


For the above reasons, I suggest the rough hummocky reflectors may correspond to a discontinuous partially-bonded subsea permafrost interface, not a geologic contact. A poorly defined partially masked reflector (R48) correlates to an ice-bonded sand interface in borehole EBA-8 (Figure 11-8). The top of an ice-bonded sand interface also correlates to R48 in borehole EBA-1 (Figure 11-5).

Sequence B probably has a more complex depositional history than Sequence $C$ and $D$. The deposits of more than one transgressional event may be preserved in Sequence $B$. Marine silt, clay, and pebbly mud are the common lithologies. Unlike Sequences C and D, Sequence B contains internal reflectors, cut and fill channels, and a paleodelta sequence. In Section 6.4 of this thesis I correlate Sequence B to transgressive deposits of the Pelukian (Sangamon) and Simpsonian (Early Wisconsin) transgressions. The basal unconformity of the Pelukian transgression is preserved as the lower boundary of Sequence B. The base of Simpsonian transgression deposits (Flaxman Member) is not observed in the acoustic records. Paleochannels cut into the surface of Sequence B were likely to have formed at a lowered sea-level after the Simpsonian tranogression. As indicated by ${ }^{14} \mathrm{C}$ date in Section 5.2, part of Sequence B is as young as Holocene.

\section{Acoustic Sequence A}

Sequence $A$ is defined as the depositional sequence between R50 and the sea-floor (Plates 1 through 3, Cross-sections A through E). An isopach map shows the thickness and distribution of Sequence $A$ (Figure 5-12). The thickness of Sequence $A$ ranges from $0 \mathrm{~m}$ to $6 \mathrm{~m}$. Up to $10 \mathrm{~m}$ of Sequence $A$ has accreted above R50 where Stamukhi Shoal is located (Plate 2, Cross-section B). Stamukhi Shoal is not a good representative thickness of Sequence A, because the shoal may contain older reworked deposits.

Sequence $A$ is mapped with Sequence A/B (Figure 5-12). R50, the lower sequence boundary, is the youngest continuous reflector below the sea-floor. This characteristic was used to identify R50 along with comparing R50 to the stratigraphic positions of deeper reflectors. R50 dips slightly seaward except along the seaward edge of Sequence $A$ where R50 dips landward and truncates at the sea-floor. R50, north of Prudhoe Bay, also dips landward, and Sequence A thickens landward (Plate 1, Crose-section A). To the west, R50 may be patchy beneath shoals. R50 is well defined again beneath Stamukhi Shoal and further west. R50 and Sequence $A$ extend into eastern Harrison Bay until the continuous character of R50 changes north of the Colville River Delta. R50 becomes discontinuous and gives the acoustic profile a "pitted" appearance (Figure 5-13). R50 becomes more discontinuous to the weat until its existence is questionable. Also, Sequence $A$ appears to thin to the west. An acoustic window occurs where R50 is discontinuous or absent. As a result, deeper reflectors, R48 (Figure 5-13) and rough hummocky reflectors, appear within Sequence $\mathbf{B}$.

The preservation of R50 as a continuous strong reflector may relate to the thickness of Sequence A. A tongue of sediments, up to $6 \mathrm{~m}$ thick, accreted in an area that trends from the Colville River Delta towards Stamukhi Shoal (Figure 5-12). R50 is well defined and continuous beneath this deposit and becomes discontinuous where Sequence $A$ thins.

Paleoscouring and modern scouring from ice gouging (Barnes et al., 1984) and strudel scouring (Reimnitz et al., 1974) may have reworked portions of the R50 interface. A zone of Chaotic reflectors is observed within $15 \mathrm{~km}$ of the Colville Delta (Figure 5-12). This chaotic zone on the delta front may consist of strudel scour crater fill deposits. As R50 is traced towards the Colville River Delta, the reflector becomes discontinuous and is truncated by the chaotic reflector zone (Figure 5-14a). The above observation may have 


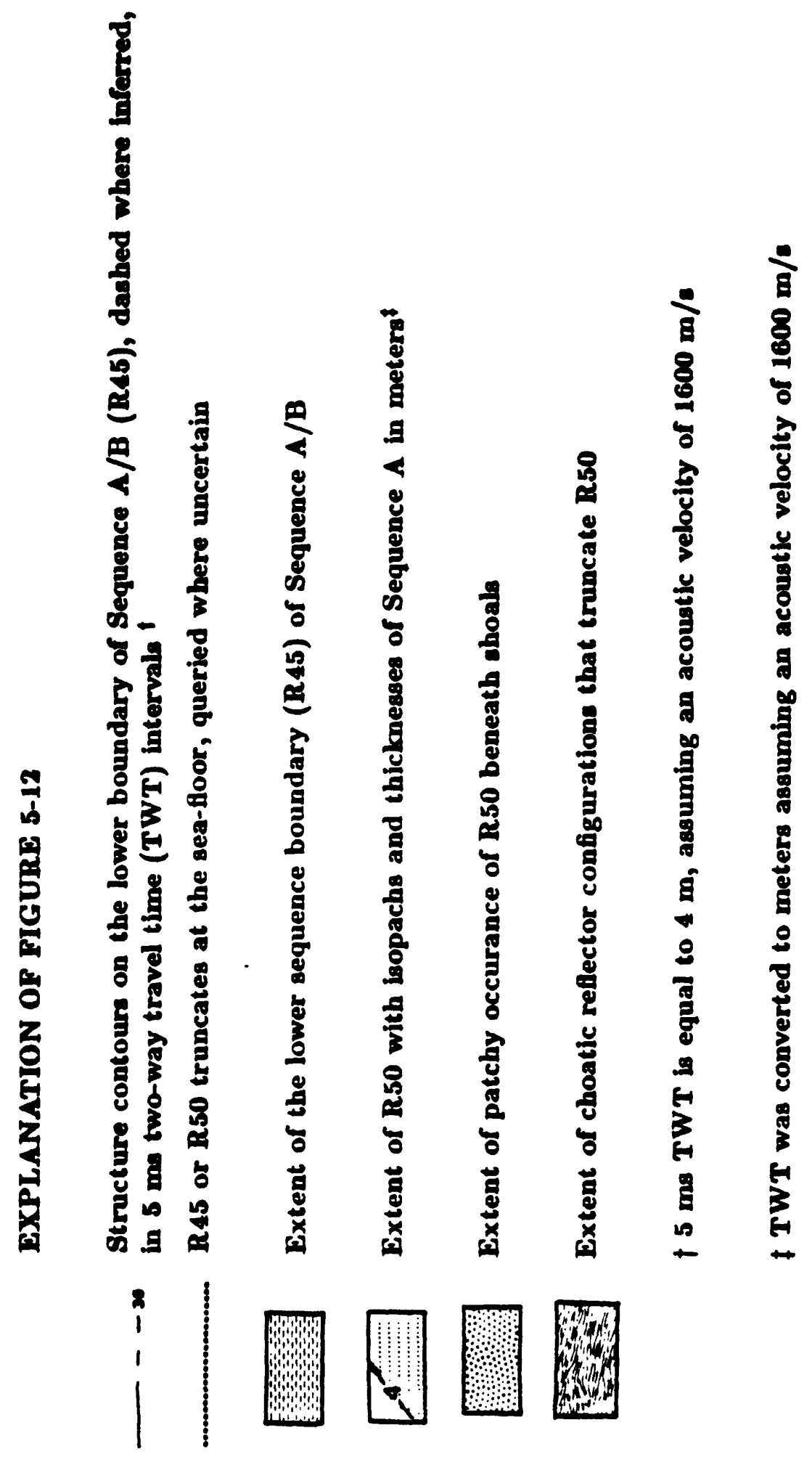




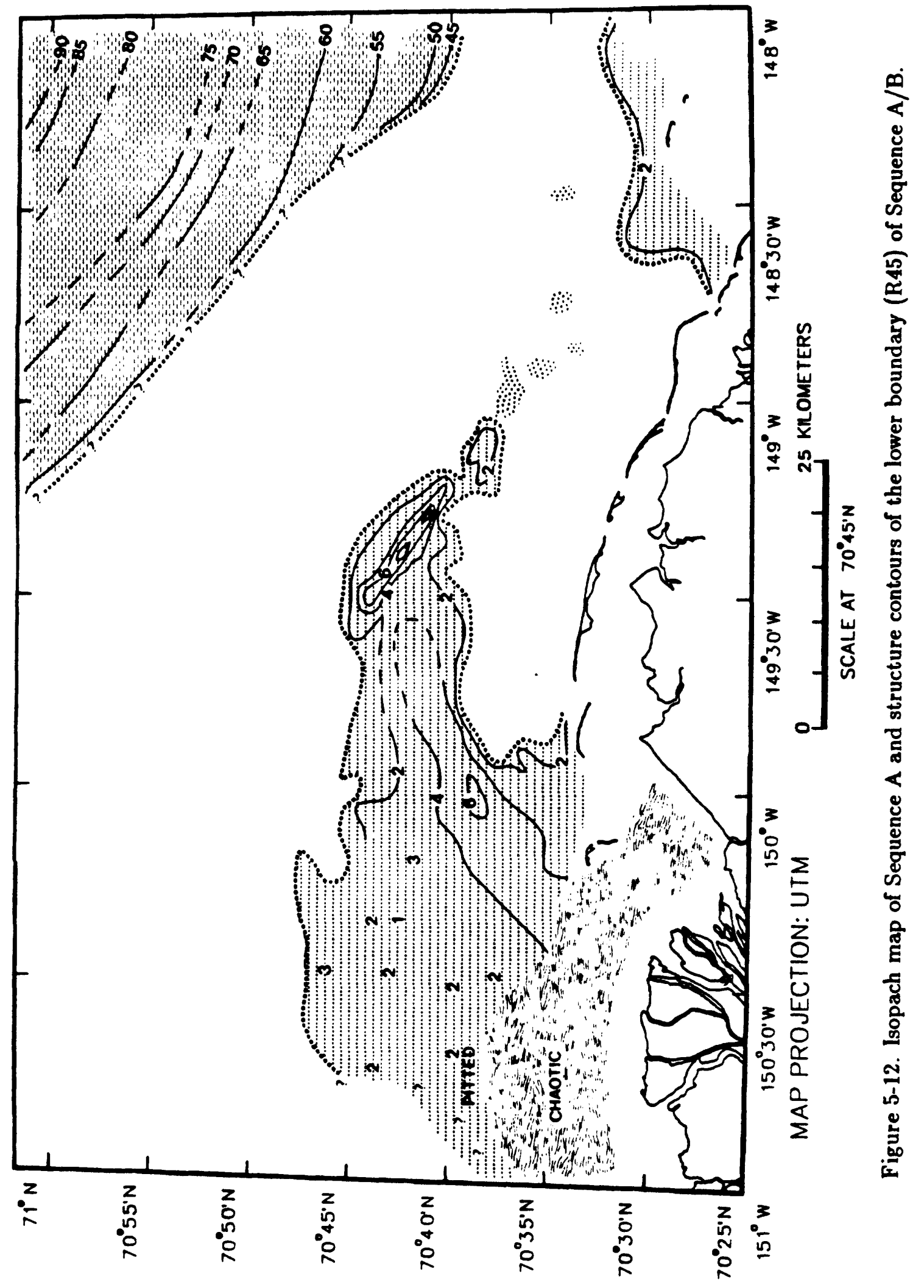




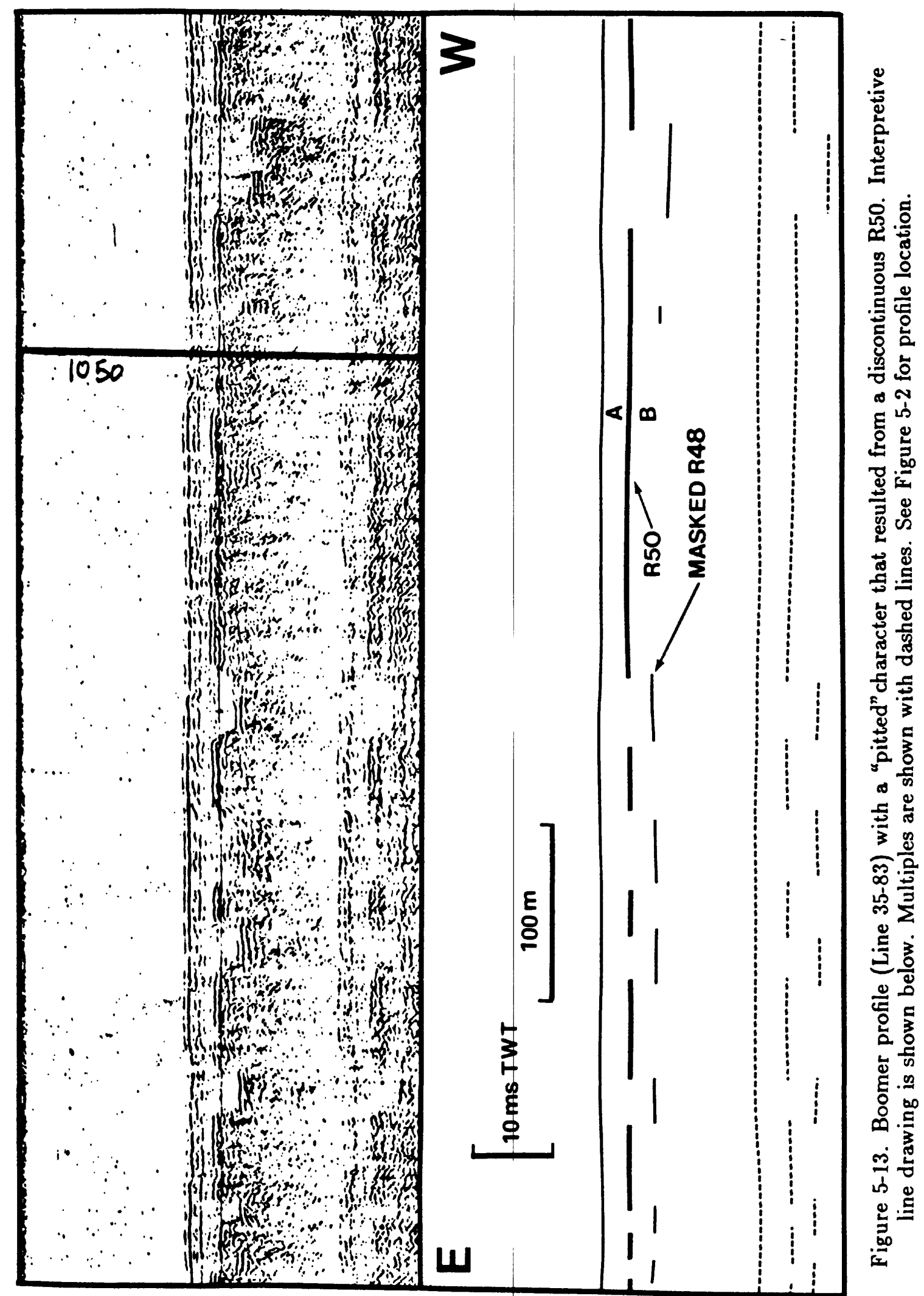




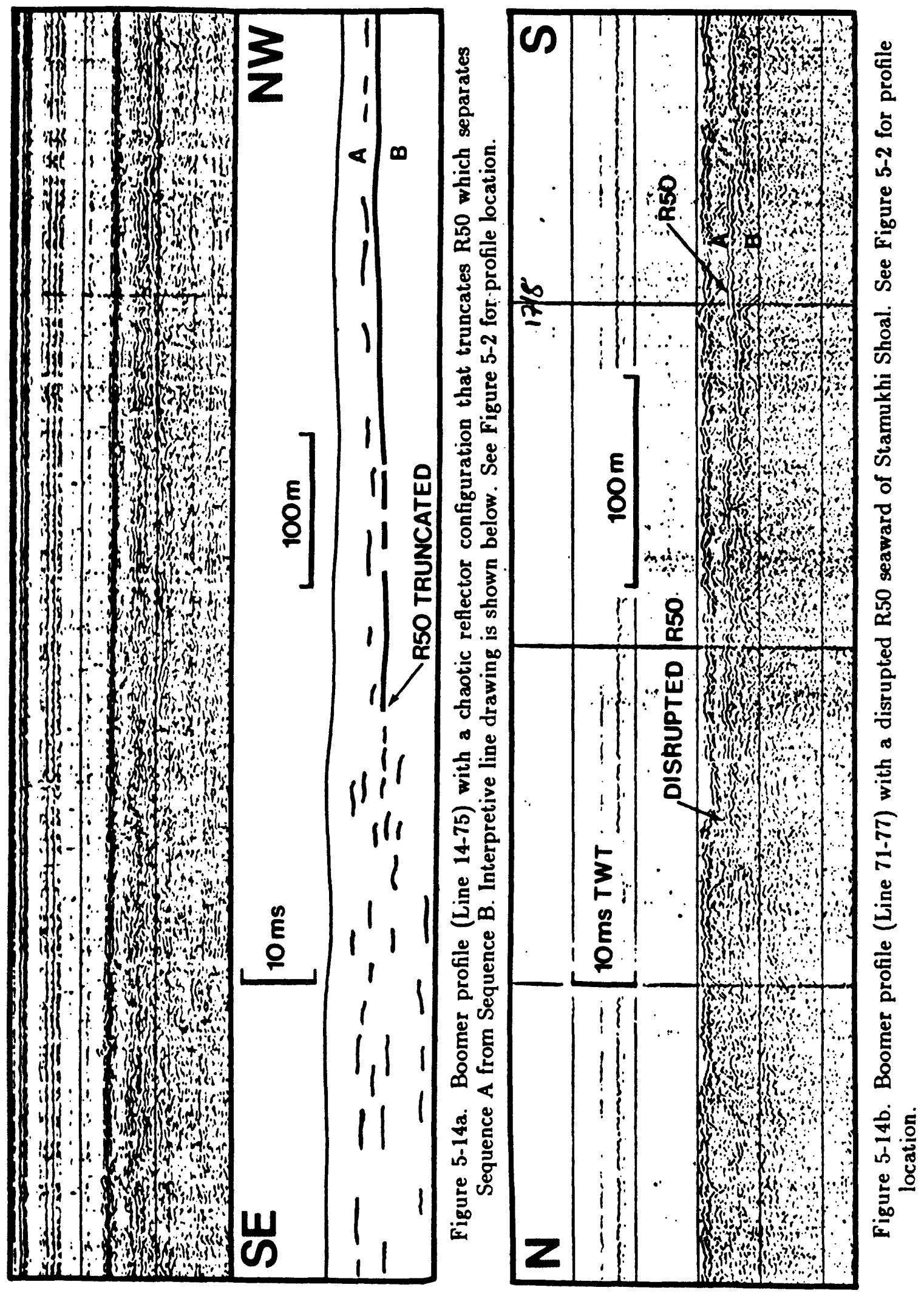


implications on the rate and activity of strudel scouring in the past. Strudel scouring may have been lees effective in reworking the shallow sub-bottom in the past, thus R50 was able to form and was buried intact. However, limited scouring may have removed some of R50 thus giving R50 a "pitted" appearance seaward of the chaotic reflector zone (Figure 5-13). Strudel scouring in the present has completely reworked the delta front and truncates R50. Ice gouging in the past and present may account for the partial removal of R50. Isolation from ice gouging processes would be necessary to preserve R50. Rapid burial or burial in a lagoon environment would have allowed for R50 to remain intact. Again, where Sequence $A$ is thin, R50 could have been disrupted by recent ice gouging. R50 appears to be disrupted seaward of Stamukhi Shoal presumably by ice gouging (Figure 5-14b).

It is also possible that R50 is absent because it never formed in some places, or the R50 interface is too thin to resolve acoustically. Speculation of the mechanism that formed R50 would require more information on the physical properties of the R50 interface.

Internal reflectors are sparse within Sequence $A$. As a result, the sequence has a transparent acoustic character. Acoustic transparency suggests Sequence A is a homogeneous deposit. The lack of internal reflectors may be due to disturbance from ice gouging. Ice gouging probably caused the transparent acoustic character of Sequence $A$, but the role that ice gouging had, if any, in forming R50 remains unresolved.

The correlation of boreholes to Sequence $\mathrm{A}$ indicates that the depositional sequence consists primarily of silt and clay. Some boreholes penetrate the basal unconformity (R50) of Sequence A. Borehole EBA-24 indicates that a lithologic contact does not correlate with the strong and continuous R50 (Figure 11-14). It is possible that the reflector interface was not sampled, since the sampling interval was done every $1 \mathrm{~m}$. The strong and continuous R50 probably does not correlate to an ice-bonded layer, because there was no significant change in the blow count during drilling operations at the R50 depth. R50 may be an overconsolidated interface. Landward of borehole EBA-24, borehole EBA-23 penetrates R50 where R50 truncates R20 and Sequence E. At this location, R50 corresponds to a lithologic contact, clayey silt over clayey sand and gravelly sand (Figure 11-13). North of Prudhoe Bay, borehole HLA-5 shows a similar silt to sandy gravel contact where R50 is located. I interpreted R50 as an erosional surface where R50 cut into coarse grained sequences; however, a nonlithologic contact, possibly a change in consolidation, was apparent where R50 is above the fine grained deposits of Sequence B.

Sequence A may be marine deposits of the Holocene marine transgression. Clay and silt lithology from borehole logs support this interpretation. $A{ }^{14} \mathrm{C}$ date discussed in Section 5.2 indicates that a Holocene age is probable for this depositional sequence. R50 is interpreted as the basal transgressive surface of the Holocene marine sequence. Borehole logs imply that R50 is erosional in some areas, but also may be a consolidated interface. On the inner shelf, Sequence $A$ thins in a seaward direction and eventually pinches out at the sea-floor. This characteristic is different from the older transgressive sequences that lie beneath Sequence A. Holocene sediments are deposited locally, thus much of the inner shelf may be an erosional or nondepostional surface. Another possibility is that Holocene marine sediments are mixed into older sediments by ice-gouging. Constant disturbace of the upper few meters of the sub-bottom by ice gouging resulted in the destruction of R50 or prevented R50 from forming, thus Sequence $A$ is not observed in the acoustic profiles.

\section{Acoustic Sequence $\mathbf{A} / \mathbf{B}$}

Sequence A/B is a seaward thickening wedge deposit that is between sequence boundaries R45 and the sea-floor in the northeast part of the study area (Figure 5-12 and Plate 
1, Cross-section A). This acoustic sequence was named Sequence A/B, because the stratigraphic relationship is uncertain between Sequence $A / B$ and Sequences $A$ and $B$ on the inner shelf. Sequence A/B lies above Sequence $B$ on the outer shelf; however, it is possible that part of Sequence $B$ on the inner shelf may be relatively younger than Sequence $A / B$. Sequence $A / B$ thickens from $0 \mathrm{~m}$ on the middle shelf to about $45 \mathrm{~m}$ on the outer shelf (Plate 1, Cross-section A).

The base of Sequence A/B (R45) dips seaward (Figure 5-12) and extends outside the study area to the outer shelf. The upper boundary of Sequence $A / B$ is defined by the sea-floor. Sequence A/B pinches out in a landward direction where R45 truncates at the sea-floor on the middle shelf. Boomer profiles from lines 751-77 and 753-77 do not show a distinct truncation of R45. This may be due to the relatively low vertical resolution of these profiles. Line 92-79 shows that R45 clearly truncates at the sea-floor. It is likely that R45 continued landward but is not acoustically resolved where the R45 truncation is queried (Figure 5-12).

Internal reflectors of Sequence $A / B$ are low amplitude and moderately continuous to transparent. The transparent character of Sequence A/B suggests a homogeneous deposit, similar to Sequences $C$ and D. Cut and fill deposits are lacking in Sequence A/B.

Sequence $A / B$ is probably a marine transgressive unit. R45 is the basal unconformity of Sequence A/B. Boreholes are unavailable to confirm this interpretation. Sequence A/B has the same acoustic character as older transgressive sequences. Sequence $A / B$ is different from the underlying transgressive sequences as it represents a large volume of deposition on the outer shelf. This may be evidence of a different sediment source for Sequence A/B.

\section{Relationships of Acoustic Stratigraphy to Shoals}

The acoustic stratigraphic framework was examined relative to shoals to determine if any relations exist. R50 is flat beneath Stamukhi and Cat Shoals. This suggests that $\mathrm{R} 50$ is not related to the construction of the shoals, rather the shoals have apparently sheltered and preserved R50 from erosive ice gouging processes. As mentioned previously, R50 extends seaward beneath Stamukhi Shoal before truncating at the sea-floor. R50 appears to be broken up by ice gouging on the seaward side of the shoal (Figure 5-14b). It is unlikely that Stamukhi and Cat Shoals are drowned barrier islands, because the base of the Holocene marine (R50) does not control the morphology of these shoals. The shoals may have been constructed from barrier islands material, but subsequent reworking and migration of the shoal has left no evidence of an ancestral island.

In addition, the stratigraphy was examined in relation to the shoals to determine the relative age of the shoal construction. Stamukhi and Cat Shoals (Figure 1-2) are above Sequence A and R50, thus these shoals were constructed after the formation of R50 during the Holocene. The shoals, particularly Stamukhi Shoal, may have migrated landward over Sequence A and R50. This may result in deposition of older reworked Sequence B sediments over younger Holocene marine sediments of Sequence A. R50 does not appear beneath Loon Shoal and Weller Bank (Figure 1-2). Loon Shoal overlies Sequence B and R20 at the base. Although an age older than R50 could be suggested, Loon Shoal likely formed after R50. Weller Bank is above rough hummocky reflectors and a deeper R40(?). The construction of Weller Bank may have been older than Holocene. An "island" of rough hummocky reflectors is beneath Weller Bank (Figure 5-8 and Plate 3, Cross-section E). These rough hummocky reflectors were previously suggested to correlate to an partiallybonded permafrost horizon within Sequence B (Figure 11-6). Borehole EBA-2 penetrates Weller Bank where an ice-bearing horizon is encountered; rough hummocky reflectors cor- 
relate to this horizon (Figure 11-6). If this "island" is a localized zone of relict permafrost, then the "island" of rough hummocky reflectors may relate to what was once a subaerially exposed topographic high. This topographic high may have been the precursor of Weller Bank.

\section{$5.2^{14} \mathrm{C}$ Analysis}

Two samples from different boreholes were dated by ${ }^{14} \mathrm{C}$ analysis. One of the boreholes, HLA-12/82 is within the study area about $20 \mathrm{~km}$ north of the Colville Delta (Figure 3-1 and Plate 3, Cross-section D). The other borehole, HLA-2/82 is located about $25 \mathrm{~km}$ west of the study area in western Harrison Bay $\left(70^{\circ} 43^{\prime}\right.$ North, $151^{\circ} 57.5^{\prime}$ West) and penetrates Pacific Shoal. The borehole logs are proprietary and were not available for use in this thesis; however, the borehole HLA-12/82 may be compared to an adjacent nonproprietary borehole EBA-8. Borehole EBA-8 encounters $9.25 \mathrm{~m}$ of silty clay over ice-bonded sand. Peat and wood fragments are interbedded with silt and clay from $4 \mathrm{~m}$ to $7 \mathrm{~m}$ below the sea-floor.

A peat sample from HLA-12/82 at a depth of $5.3 \mathrm{~m}$ below the sea-floor or $18.3 \mathrm{~m}$ below present sea-level was dated. $A{ }^{14} \mathrm{C}$ date of $7500 \pm 150$ years B.P. (HLA-12/82, 17.2-17.5) was obtained. The significance of the date is that it provides a maximum age of R50 and the overlying Sequence A within the vicinity of the borehole. The sample consisted of a silty peat, mostly moss and some twigs. This peat sample may have been deposited as a allocthonous organic debris in a detrital environment. Marine microfossils were absent in the sample which suggests but does not confirm that the peat was deposited in fresh water. However, a single fossil is tentatively identified (Kristy McCumby, personal communication, 1987) as a marine gastropod of the Family Naticidae in a sample $30 \mathrm{~cm}$ below the dated peat; probably the fossil was deposited within a few meters of the former sea-level. A deltaic deposit is a reasonable interpretation for the dated sample. The stratigraphic position of the dated sample is superimposed on to two acoustic profiles that were in the vicinity of HLA-12/82 (Figure 5-15). The dated sample is within Sequence B with $R 50$ and Sequence $A$ above. The date indicates that sediments deposited above the dated sample are not older than $7500 \pm 150$ years B.P.. Reworking and redeposition of the sediments was considered, since ice gouging and strudel scouring may have disrupted the sediments. R50 is a moderately continuous reflector near the borehole (Figure 515). To mix younger sediment below R50, reworking would have occurred before the formation of R50, otherwise R50 would appear discontinuous or would be absent from the acoustic profile. Since R50 is intact in this location, Sequence $A$ and the upper part of Sequence $B$ are Holocene at this location. The age obtained from this borehole can not be extrapolated to date all of Sequence A, because R50 is interpreted as a time transgressive surface. Sequence A and R50 should be progressively older seaward of HLA-12/82. The position of $R 50$ relative to the date suggests that the geologic significance of $R 50$ may be related to the Holocene transgression.

A sample from Pacific Shoal in western Harrison Bay was dated. The sample is from a depth of $3.2 \mathrm{~m}$ below the sea-floor or $5.2 \mathrm{~m}$ below present sea-level and consists of clean meshed peat comprised of moss. No microfossils were found in the sample. I interpreted this tightly meshed peat as a coastal plain deposit. $\mathrm{A}{ }^{14} \mathrm{C}$ date of $8880 \pm 140$ years B.P. (HLA-2/82 17.65-17-85) was obtained. Acoustic profiles in the area of Pacific Shoal are poor in quality due to bottom multiples in the shallow water, thus a direct correlation is not possible. A shallow hummocky reflector is near the shoal, and R50 was not encountered in this region. The in situ nature of the peat deposit suggests a maximum Holocene age for the overlying $3.2 \mathrm{~m}$ of sediment. The peat probably accumulated up to 


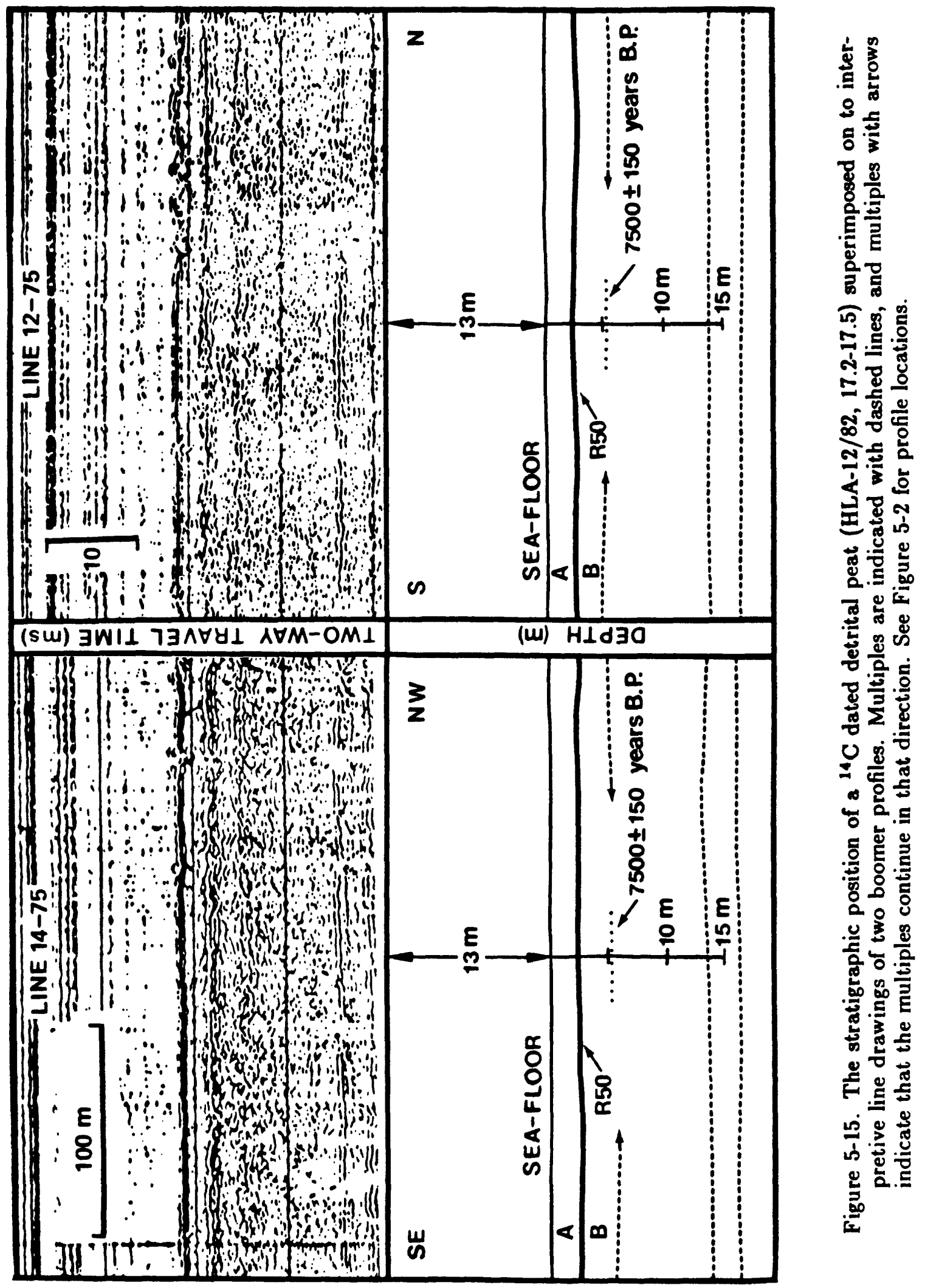


$15 \mathrm{~m}$ above sea-level at the time, because this peat is older than the peat (HLA-12/82) that is interpreted to be deposited near a past sea-level $(18.3 \mathrm{~m}$ below present sea-level).

\subsection{Subsea Permafrost and Gas-bearing Sediment}

The presence of subsea permafrost and gas-bearing sediments can not be ignored in the interpretation of the acoustic profiles. Queried reflectors (R20(?) ,R30(?), R40(?)) in the western part of the study area appear to be enhanced possibly by ice or gasbearing sediment. These reflectors may not be stratigraphic features. If they are related to real geologic features, they may be enhanced by stratigraphically controlled permafrost or trapped gas beneath a overconsolidated horizon. The presence of the apparent gasenhanced reflectors in association with the paleodelta sequence suggests that organic deltaic deposits are the probable source of gas. Acoustically turbid zones that prevent correlation between queried reflectors, R20, R30, and R40 may be related to gas-bearing sediments. R30 appears to be enhanced on Line 751-77 in the middle shelf region (Figure 5-16). The reflection at the R30 interface is anomalously bright compared to R40 and the sea-floor. Several possible faults occur at the R30 interface. Attenuation and reflector pulldown is evident near apparent fault planes (Figure 5-16) suggesting that gas may be concentrated in the sediments near faults. The high amplitude of R30 may be due to trapped gas beneath an impermeable horizon. Ground truth is not available to confirm the above interpretations.

Some reflectors are correlated to borehole logs that indicate ice-bearing sediments. Boreholes EBA-1 and EBA-8 show that R48, within Sequence B, is at the surface of an ice-bonded sand horizon. This observation suggests the reflectors are from real geologic features, and the subsea permafrost is stratigraphically controlled. Rough hummocky reflectors within Sequence B are an example where subsea permafrost does not conform to lithologic unit. Borehole evidence suggests the reflector is a result of a partially-bonded horizon; therefore, this reflector should not be interpreted as a geologic contact.

The ATB can be explained as an acoustical phase change from ice-bearing sediment to sediments free of ice. In this instance, the distribution of subsea permafrost probably relates to the depositional history of Sequence $B$. A conceivable geologic explanation is that the ATB may correspond to a paleoshoreline. Increased acoustic transmission seaward of the ATB may relate to a filled embayment. The ATB would be proximal to the paleoshoreline. Permafrost aggraded and is preserved as relict subsea permafrost in sediments on the shoreward side of the ATB. The presence of a prograding prodelta sequence seaward of the ATB, delta plain, and delta front deposits near the ATB (Plate 2, Cross-section C) supports the presence of a paleoshoreline. Delta foresets downlap on to R20(?), R30(?), and R40(?) suggesting that a paleoembayment occurred seaward of the ATB. The queried reflectors predate the embayment since they seem to extend in the sub-bottom beneath the rough hummocky reflectors in Harrison Bay.

\subsection{Summary of Results}

At least five major depositional sequences exist on the Beaufort Sea shelf within the study area. Major reflectors, interpreted to be unconformities, define acoustic sequence boundaries. Reflectors are truncated in the sub-bottom or at the sea-floor on the inner shelf. This particularly applies to the region seaward of Pingok Island, where little deposition has occurred after the massive fluvial sediments of Sequence E were deposited. Nondeposition and some erosion was likely due to sea-level lowstands when sediments bypassed the inner shelf and were transported to the outer shelf and slope. The unconformities were modified during sea-level transgressions that resulted in continuous planer 

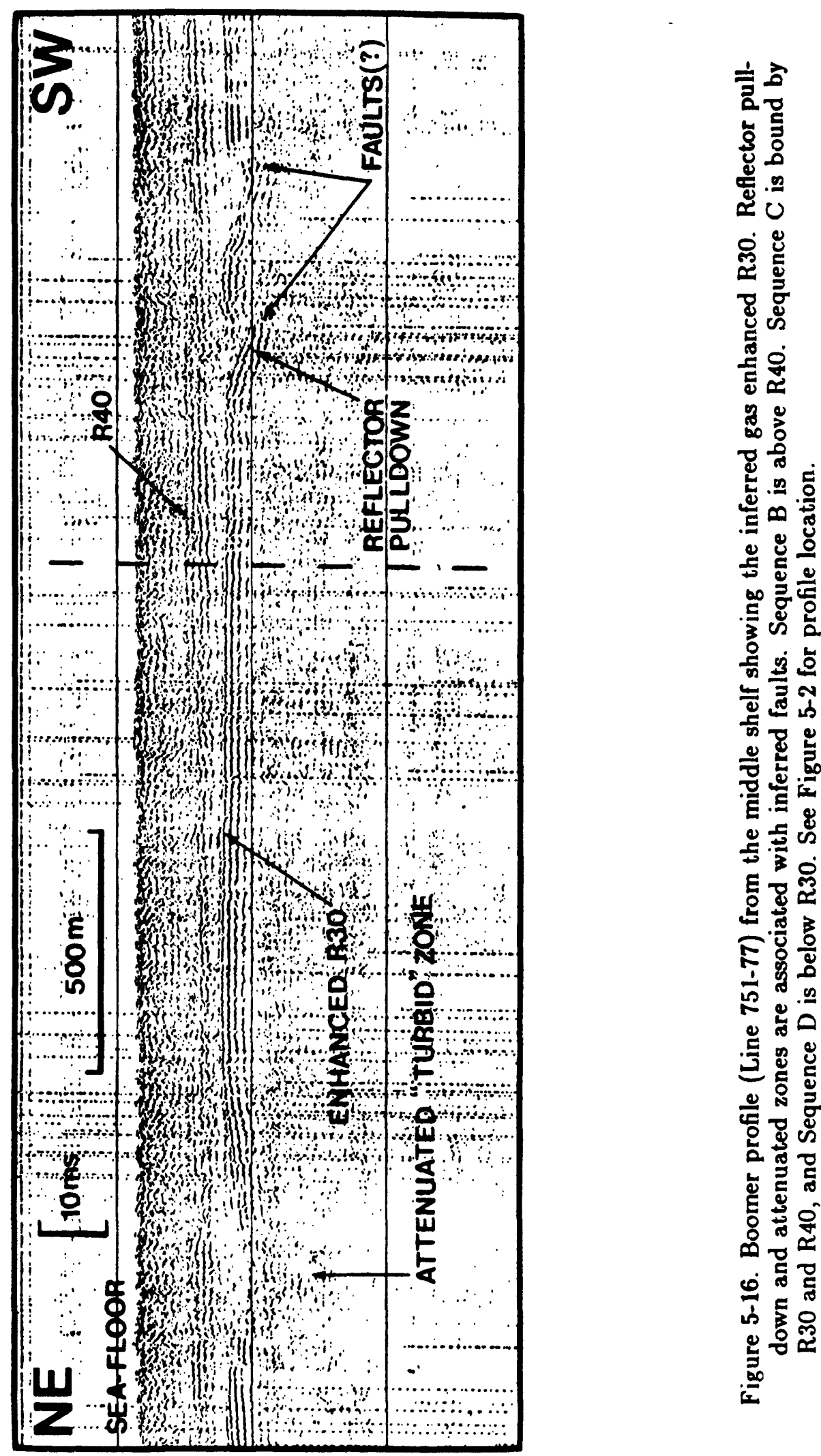
unconformities or reflectors on the acoustic profiles. Sequences $A$ through D are primarily transgressive deposits. Sequence $E$ is a regressive sequence that was deposited on the inner shelf during a sea-level lowstand. Cut and fill channels and a delta sequence within Sequence B suggest that the upper part of Sequence B may contain some regressive deposits. A sea-level stillstand may have occurred during Sequence B deposition and is preserved as a buried shoreline and delta sequence within Sequence B. Transgressive depositional sequences usually thicken seaward except Sequence $A$. Sequence $A$ is suggested to be a Holocene marine transgressive deposit, based on a ${ }^{14} \mathrm{C}$ date. Sequence $A$, is thin, patchy, and absent on the inner shelf. The thickest Holocene marine deposits seem to have a source from the Colville River in eastern Harrison Bay. This deposit may be temporary, as the seaward edge of Sequence $\mathbf{A}$ is undergoing erosion and reworking near at the stamukhi zone. The observations suggest that the Holocene transgression differed from previous transgressions. At least some of sequences $B, C$, and $D$ were preserved in the stratigraphic record. Sequence $A$ does not thicken seaward and appears to be degraded where the sequence is thin. Sequence $A$ eventually may not be preserved in the stratigraphic record as earlier transgressions have been. Unfortunately, no correlation can be made between Sequence $A$ and Sequence $A / B$. This correlation would be necessary to comment on Holocene marine deposition on the outer shelf.

\subsection{Correlation of Acoustic Stratigraphy}

Acoustic stratigraphy from this thesis is correlated to the acoustic stratigraphy developed in previous studies (Table 6-1). Differences and similarities between interpretations are considered.

Interpretations of stratigraphy by Reimnitz et al. (1972) are correlated to the acoustic stratigraphy (Table 6-1). Their horizon B correlates with R10 in the Oliktok Point area. They suggest that the unit between horizon $B$ and horizon $A$ is a Pleistocene deposit of the Quaternary Gubik Formation. This unit correlates best with Sequence E, and the lower boundary of Sequence E (R10) correlates to horizon B. No correlation is made with Sequences B, C, and D, since the relatively low resolution of the sparker data obtained by Reimnitz et al. (1972) is unable to resolve these sequences on the inner shelf. The unit between horizon $A$ and the sea-floor correlates partially to Sequence A, thus R50 should be the equivalent of horizon $A$. The greater thickness of sediments above horizon A (Figure 2-2) compared to Sequence A (Figure 5-12) can be explained by the improved resolution of the boomer over the sparker system. R20, R30, and R40 may have been misinterpreted by Reimnitz et al. (1972) as the base of the Holocene marine unit where Sequence $A$ is too thin to resolve on the sparker profiles.

East of the study area, R30, R40, and R50 are tied to reflectors identified by Wolf et al. (1985) (Table 6-1). This was done by comparing two-way travel times (TWT) between a profile (Line 66-77) interpreted in this study and by Wolf et al. (1985). R30 corresponds to their surface 3, and R40 equals surface 4. Wolf et al. (1985) showed that surfaces 3 and 4 converge on the inner shelf and to the west. The area where these surfaces converge is mapped as R30=R40 in this thesis (Figure 5-6). R50 north of Prudhoe Bay (Figure 5-12) ties to surface 5 ? (Wolf et al., 1985). The Holocene marine sediments above surface 5 ? (Figure 2-5) correspond to Sequence A. Holocene marine deposits are restricted to lagoons to the east of the study area and become patchy west of Prudhoe Bay. I assumed that Sequence $A$ in eastern Harrison Bay is the same Holocene marine unit to the east. Direct correlation is not possible, because Sequence $A$ is patchy to nonexistent between the two 


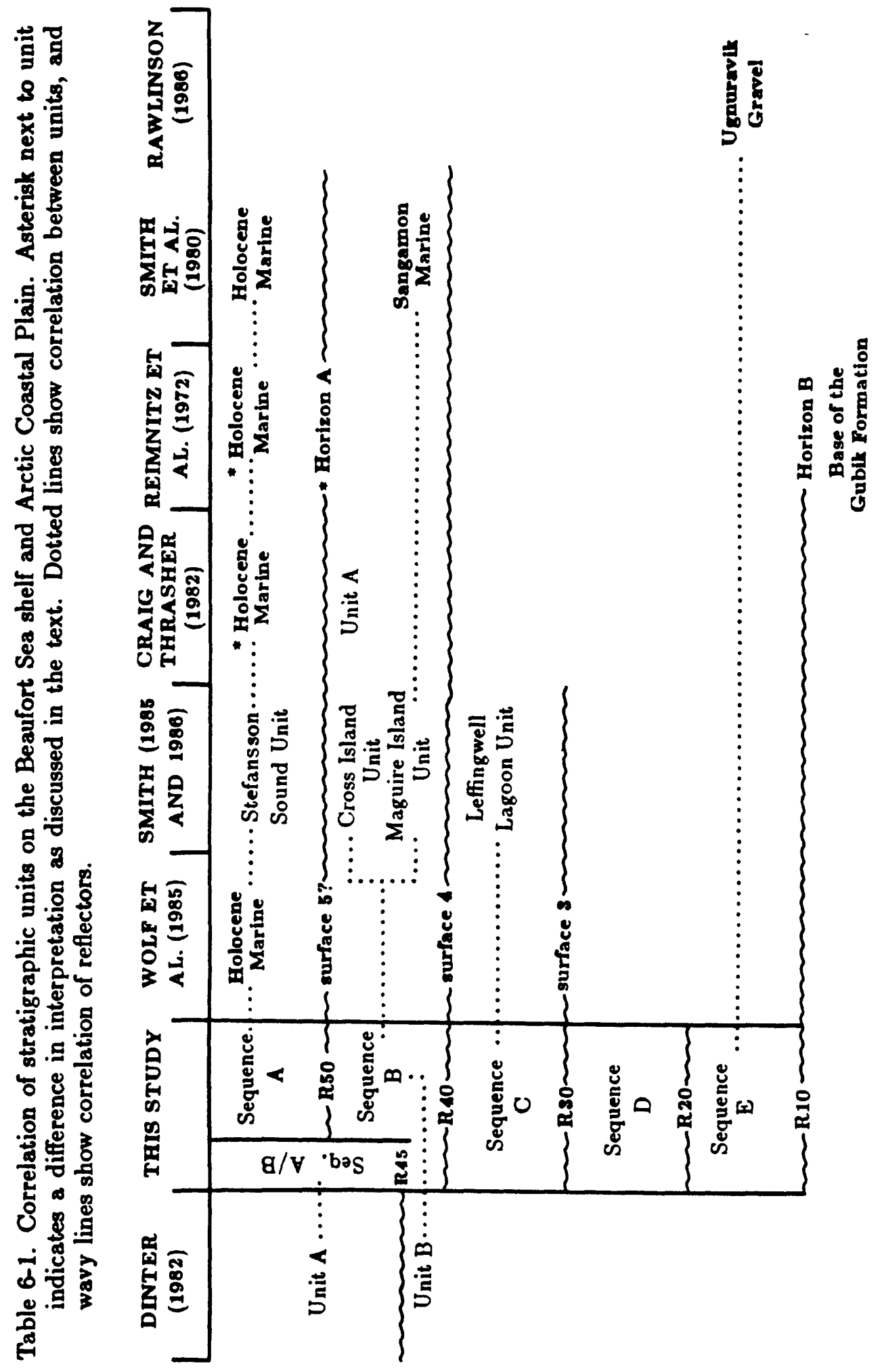


deposits and can not be traced on the acoustic profiles. The above correlations show that the acoustic sequences developed in this study correlate to deposits between continuous reflectors identified by Wolf et al. (1985) east of the study area.

The western part of the study area overlaps the survey grid of acoustic profiles interpreted by Craig and Thrasher (1982) and Vralsted (1986). I was able to compare and contrast with their interpretations.

Craig and Thrasher's (1982) Unit A corresponds to my Sequence B; they infer that sediments above Unit $A$ are Holocene marine, similar to my interpretation of Sequence A (Table 6-1). However, my interpretation of the Holocene marine contrasts with their suggestion that rough hummocky reflectors in Harrison Bay represent a buried coastal plain surface. I agreed with an alternative suggestion (Craig and Thrasher, 1982) that this reflector is caused by an ice-bearing interface rather than a lithologic horizon. The differences in the interpretation of the lower boundary of the Holocene marine results in differences in distribution and thickness of Holocene marine deposits. Craig and Thrasher (1982) suggested that Holocene marine sediments thicken from $2 \mathrm{~m}$ to $25 \mathrm{~m}$ in a seaward direction, whereas I suggested that Holocene marine sediments (Sequence A) pinch out in a seaward direction (Figure 5-12). If my interpretations are correct, then the Holocene marine unit mapped by Craig and Thrasher (1982) overestimates the thickness and distribution of Holocene marine deposits.

Craig and Thrasher (1982) interpreted an abrupt thickening of Holocene marine deposits to occur seaward of a buried bluff that marks the position of a paleoshoreline. I mapped the position of the "bluff" as the Acoustic Transmission Boundary (ATB) (Figures 5-7 and 5-8). Craig et al. (1985) suggested that the "bluff" may represent an abrupt depth change to the top of the ice-bonded permafrost horizon, thus the "bluff" may not be a buried geologic contact. A paleodelta sequence preserved proximal to the ATB suggests that a paleoshoreline and embayment are present. Prograding delta foresets downlap on to Craig and Thrasher's (1982) Pleistocene Unit B. Several reflectors, R20(?), R30(?), and R40(?) correlate to the surface of Unit B. Deltaic sediments filled the paleoembayment that existed seaward of the ATB. Based on the acoustic transparency and lack of rough hummocky reflectors, the embayment fill may have been relatively free of ice-bearing sediment. Vralsted (1986) interpreted regions with several reflectors, such as the paleoembayment, as acoustically clean (where more acoustic energy is transmitted to deeper reflectors) sediments that are free of ice. He suggests that rough reflectors are a transition from ice-bonded to the ice free zones. Partially-bonded permafrost in boreholes correlate with rough hummocky reflectors (Figures 11-6 and 11-7). The area of rough hummocky reflectors appears to define the distribution of relict permafrost that aggraded on the subaerially exposed side of the paleoshoreline, and the acoustically clean zone represents ice free marine deltaic deposits that filled the paleoembayment. The ATB does not appear to be a buried bluff; however, the ATB appears to show the position of a paleoshoreline.

The age of this inferred paleoshoreline is suggested to be Pleistocene by Craig and Thrasher (1982). The age of the paleodelta sequence proximal to the ATB would be useful in determining the age of the paleoshoreline. Dinter (1985) suggested that paleodeltas, located east of the study area on the Beaufort shelf, were deposited about 36,000 years B.P. when fluvial flux to the shelf was high. The relatively high angle of the buried delta foresets indicate a relatively high energy depositional environment compared to the present Colville Delta. Delta progradation was less likely to occur during the drier climate that was present between 36,000 and 12,000 years B.P. when eolian dune fields were active on the coastal plain (Carter and Galloway, 1985). The age of the paleoshoreline and delta 
sequence in Harrison Bay could be Holocene or older than 36,000 years B.P.. In Section 6.5, I suggest that a Holocene age is unlikely.

R50 becomes discontinuous and appears "pitted" (Figure 5-13) in eastern Harrison Bay. Craig and Thrasher (1982) suggested some of the "pitted" features may relate to cut and fill channels, filled thaw lakes, and a buried tundra surface. Vralsted (1986) suggested that gas-bearing sediments may cause pitted reflectors, spotty reflectors, acoustical voids, and acoustic "windows" to deeper reflectors. The "pitted" reflectors that Vralsted (1986) describes coincide with the "pitted"R50. I noted that R50 was discontinuous where Sequence $A$ is thin and well preserved where Sequence $A$ is thick. Perhaps strudel scour and ice gouging has removed some of the R50 interface. Partial strudel scouring may have penetrated and reworked some of R50, thus R50 appears "pitted". Where Sequence A is thin, R50 may have been disrupted by recent ice gouging. If R50 was formed in a marine environment, then the "pitted" character is probably not caused by relict coastal plain features. I suggest that R50 formed in a shallow marine environment, and subsequent burial has preserved R50 from ice gouging and strudel scour.

Two shelf normal profiles (Lines 751-77 and 753-77) were used to correlate the inner shelf stratigraphy to the outer shelf stratigraphy of Dinter (1982) (Table 6-1). This was done by comparing the profiles interpreted in this study to an isopach map of Holocene sediments (Unit A) (Dinter, 1982). Sequence A/B is the equivalent of Unit A, and R45 lies between Unit A and Unit B on the outer shelf. Unit B correlates to the upper part of Sequence B on the outer shelf (Plate 1, Cross-section A). The lack of age information on Sequence A/B and Sequence B on the outer shelf provides no insight on Dinter's (1982) interpretation of Unit A as a Holocene transgressive deposit. Also, Sequence A (Holocene marine) can not be tied to Sequence $A / B$, because Sequence $A / B$ wedges out on the middle shelf. Sequence $A / B$ lies above thus postdates part of Sequence $B$ on the outer shelf. $A{ }^{14} \mathrm{C}$ age within Sequence $B$ on the inner shelf is Holocene (Figure $5-15)$. This could be interpreted to suggest that Sequence $A / B$ is as young as Holocene, because Sequence A/B lies above Sequence B on the outer shelf. However, based on the stratigraphic framework (Plate 1, Cross-section A), it is possible that Sequence A/B is deposited within Sequence B, not above. Age determination of the R45 interface is necessary to make further interpretations.

The acoustic stratigraphy reported here is in agreement with the work of Reimnitz and Maurer (1978) and Reimnitz and Kempema (1984) on the origin of shoals. These studies suggest that Stamukhi Shoal was constructed during the Holocene transgression, based on evidence from acoustic reflection records (Reimnitz et al., 1972). Their interpretation is consistent with the observation that R50 is flat beneath Stamukhi Shoal. This is contrary to Lewellen's (1977) interpretation that linear shoals on the inner shelf are drowned barrier islands. I also agree with Reimnitz and Maurer (1978) that Stamukhi and Cat Shoals are constructed over a different stratigraphic unit than the unit beneath Loon Shoal. This relationship was explained in Section 5.1. Reimnitz and Maurer (1978) point out that the differences in stratigraphic framework beneath the shoals could account for differences in surficial composition of the the shoals.

Other shoals were compared to Stamukhi Shoal to determine if the shoals have a common origin. Weller Bank is superficially similar to Stamukhi Shoal both lithologically and in ice gouge density (Barnes and Reiss, 1981). Reimnitz and Kempema (1984) point out that Stamukhi Shoal is more linear and has higher relief than Weller Bank. Perhaps this observation indicates that Stamukhi Shoal has encountered more reworking and modification than Weller Bank has. The sub-bottom of Weller Bank is different from the 
subsurface of Stamukhi Shoal. Weller Bank appears to be a relict form, because the shoal overlies a local zone of relict permafrost (Section 5.1). Stamukhi Shoal is a Holocene constructional feature, because the shoal is deposited over R50. R50 is interpreted to relate to the Holocene transgression. The linearity and relief of Stamukhi Shoal suggests that constructional processes, reworking, and possibly migration of the shoal is more active than the relatively stable Weller Bank. Stamukhi Shoal may have migrated landward over R50 depositing reworked sediments over Sequence A. Reimnitz and Maurer (1978) indicated that Stamukhi Shoal appears to be migrating slowly landward. Their observations for a 25 year period show that the shoal crest has remained stationary in some locations and has moved landward in others. At one location of the shoal crest the maximum landward displacement is measured to be about $200 \mathrm{~m}$ in 25 years.

The migration of Stamukhi Shoal is inferred from the physical properties of R50, and the interpretation that R50 represents a basal Holocene transgressive surface. R50 truncates at the sea-floor in areas mapped by Reimnitz and Kempema (1984) as overconsolidated mud outcrops on the leeward side and northwest flank of Stamukhi Shoal. These outcrops are consistent with truncations of R50 at the sea-floor as observed on the acoustic profiles. This supports the contention that the R50 interface is an overconsolidated surface where lithologic contacts do not correlate with R50 (Figures 11-13 and 11-14). An overconsolidated layer, possibly the basal transgressive surface of Holocene marine deposits, is expected to produce a strong and continuous reflector such as $\mathrm{R} 50$. If the interpretation of R50 as a Holocene transgressive surface is correct, then Stamukhi Shoal migrated over R50 during the Holocene transgression.

Processes leading to overconsolidation are believed to be caused by alternate freezing and thawing of sediment (Chamberlain et al., 1978). Alternate freezing and thawing that leads to overconsolidation of sediments may occur when the shelf surface is subaerially exposed during sea-level lowstands, or in the shallow marine environment where fast ice grounds to the sea-floor (Lee et al., 1985). Also, contact of cold hypersaline water with relatively fresh sediment pore water can cause ice-bonding of the sea-floor sediment and result in overconsolidation of the sediment (Lunardini, 1981; Sellmann and Hopkins, 1983). Foraminifera within overconsolidated mud indicate deposition in a shallow (2-4 $\mathrm{m}$ ) marine setting (Reimnitz et al., 1980, citing Ron Echols, unpublished data). A ${ }^{14} \mathrm{C}$ date from one sample containing the shallow marine foraminifera was dated at 4,360 \pm 95 years B.P. (Station 41, 72AER 188) (Reimnitz et al., 1980). This evidence suggests that some overconsolidated mud may have formed close to the basal Holocene transgressive surface as suggested by Reimnitz et al. (1980). Three other ${ }^{14} \mathrm{C}$ dates $(3,466 \pm 292,11,810 \pm$ 280 , and $11,890 \pm 200$ years B.P., Stations 23 72AER 122, 29 72AER 183, and $4672 \mathrm{AER}$ 129) of sea-floor overconsolidated muds reported by Reimnitz et al. (1980) are within the range expected of the Holocene transgression. The locations of these dated samples are shown in Figure 6-1. One overconsolidated sample deposited above a peat bed is exposed in a strudel scour crater in Gwydyr Bay; a date of 4,118 \pm 189 years B.P. (Station 32) resulted on the peat.

An overconsolidated mud, containing marine pelecypods, that outcrops at the seaward base of Loon Shoal (Figure 6-1) was ${ }^{14} \mathrm{C}$ dated at $11,280 \pm 280$ years B.P. (Station 29 72AER 183) (Reimnitz and Maurer, 1978). This suggests that Loon Shoal was constructed over an overconsolidated mud that relates to a Holocene transgressive surface. However, R50 was not observed beneath Loon Shoal.

A dive observation (Reimnitz and Maurer, 1978) describes patches of consolidated sandy gravel within Cat Shoal. The consolidated sediments above R50 is inconsistent 


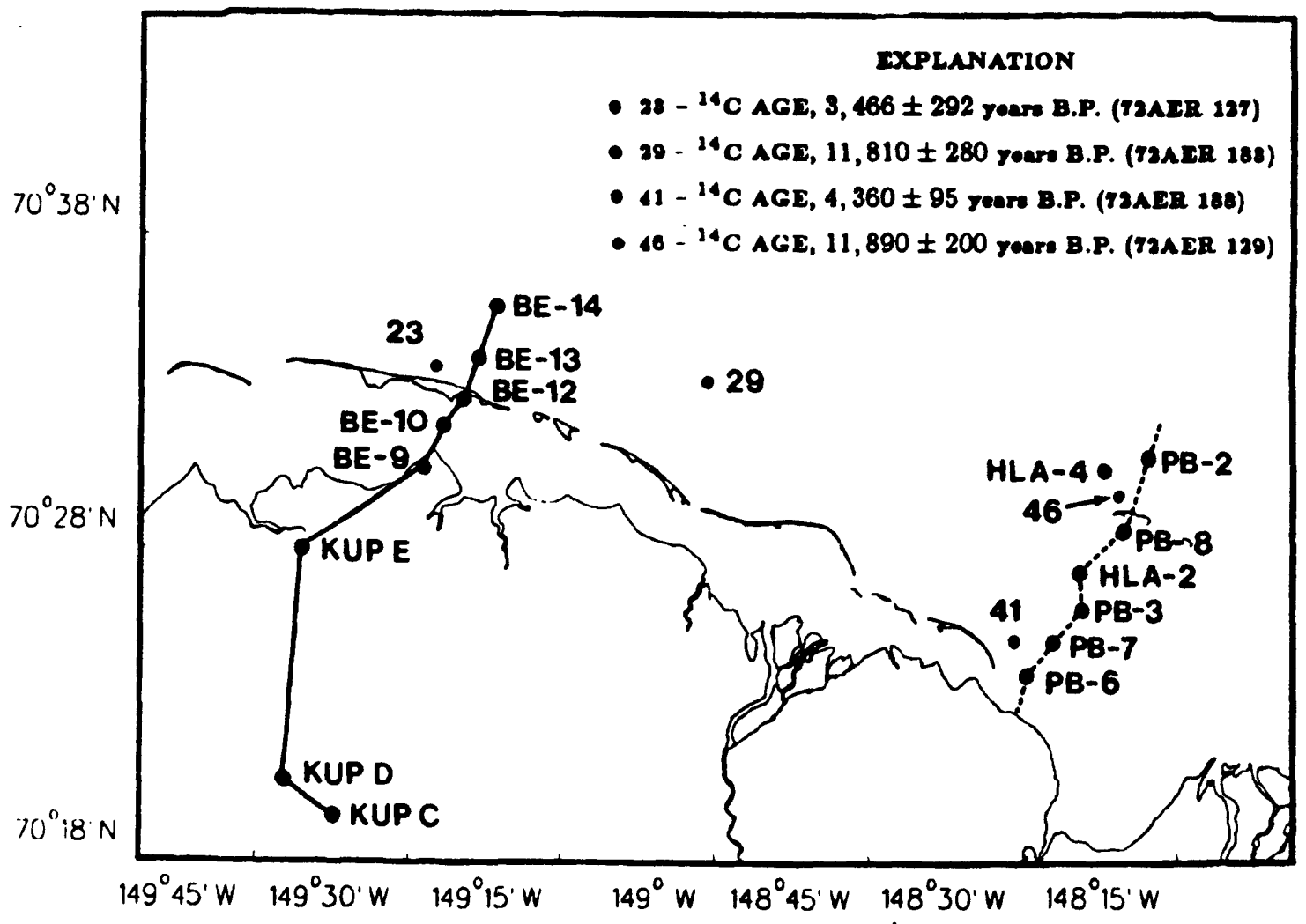

Figure 6-1. Locations of transects and ${ }^{14} \mathrm{C}$ dated samples. Solid transect line ties boreholes (BE) of Benton Engineering (1970) to gravel pit (KUP) stratigraphy of Rawlinson (1986). Dashed line shows location of a borehole transect constructed by Smith et al. (1980). Boreholes (PB) form Hopkins, 1977 and (HLA) Harding-Lawson (1979) are plotted on the transect. Station locations of ${ }^{14} \mathrm{C}$ dated samples are also plotted. 
with the suggested Holocene age for deposits above R50, assuming that the sediments were consolidated subaerially.

\subsection{Correlation of Acoustic Stratigraphy to Offshore Borehole Stratigraphy}

Correlation was possible with the borehole stratigraphy by Smith (1985 and 1986), because the acoustic stratigraphy was correlated to reflectors east of the study area (Wolf et al., 1985). Based on Smith's (1986) correlation of surface 3 (R30) and surface 4 (R40) to boreholes, I was able to tie the acoustic sequences to the borehole stratigraphy of Smith (1985) (Table 6-1).

Sequence C, between R30 and R40, corresponds to the Leffingwell Lagoon Unit (Smith, 1985). Smith (1986) describes this unit as marine silt and clayey silt overlying a beach gravel with an erosional upper contact. The lower contact would produce a strong reflector by the nature of the lithologic interface, and the upper erosional surface would produce varying reflector amplitudes. The description of this unit fits the acoustic interpretation of Sequence $\mathrm{C}$ as a marine deposit that has an erosional upper surface (R40).

The Maguire Island Unit mantles the erosional unconformity that corresponds to R40. Thus, the Maguire Island unit correlates to the base of Sequence B. Smith (1985) described this unit as shallow shelf and delta front deposits. She suggested that thick deltaic deposits originated from high terrigenous influx during the Sangamon interglacial.

The next younger unit, the Cross Island Unit, correlates to the upper portion of Sequence B. Smith (1985) notes that the Cross Island Unit has Flaxman-like lithologies and suggests a correlation to the Flaxman Member of the Gubik Formation. She also identified in one borehole, the Mikkelsen Bay Unit, a cut and fill deposit with channel lag deposits of Flaxman Member lithology. This unit cuts into the Cross Island Unit. Cut and fill channels observed in the upper part of Sequence B in the acoustic profiles may correlate with the Mikkelsen Bay Unit.

The youngest unit, the Stefansson Sound Unit, is interpreted to be Holocene marine and deltaic deposits. (Smith, 1985). The base of this unit correlates to surface 5 ? (Wolf et al., 1985). Based on this, I interpreted Sequence $A$ to be the equivalent of the Stefansson Sound Unit. Smith (1985) described the upper part of borehole HLA-15 and the entire unit in borehole HLA-14 as similar to recent lagoonal deposits.

Several boreholes from the Prudhoe Bay region (Hopkins, 1977; Harding-Lawson, 1979; Hartz et al., 1979) are interpreted and the stratigraphy summarized in geologic cross-sections by Smith et al. (1980). One of their transects is on the eastern margin of the study area (Figure 6-1). Two boreholes from this transect, HLA-4 and PB-2 (Figures 1116 and 11-18), are tied directly to the acoustic stratigraphy of this thesis. Unfortunately, the acoustic reflection data that networks the borehole data in the Prudhoe Bay area, landward of Reindeer Island, are of poor quality. I was unable to interpret these lines.

A stratigraphic cross-section (Figure 6-2) is constructed from a transect of boreholes from the shore near the ARCO West Dock to $5 \mathrm{~km}$ beyond Reindeer Island (Figure 6-1) (Smith et al., 1980). Their interpretation showed Holocene deltaic, marine, and beach gravel deposits overlying Pleistocene fluvial and glaciofluvial deposits. The contact of the Holocene marine unit over Holocene beach gravel presumably corresponds to R50, and the sediments above the base of the Holocene marine are equivalent to Sequence $A$. A broad trough containing ponded Holocene sediment that overlies Pleistocene gravel (Figure 6-2) is interpreted by Hopkins et al. (1979) as a buried paleovalley. Landward dipping 


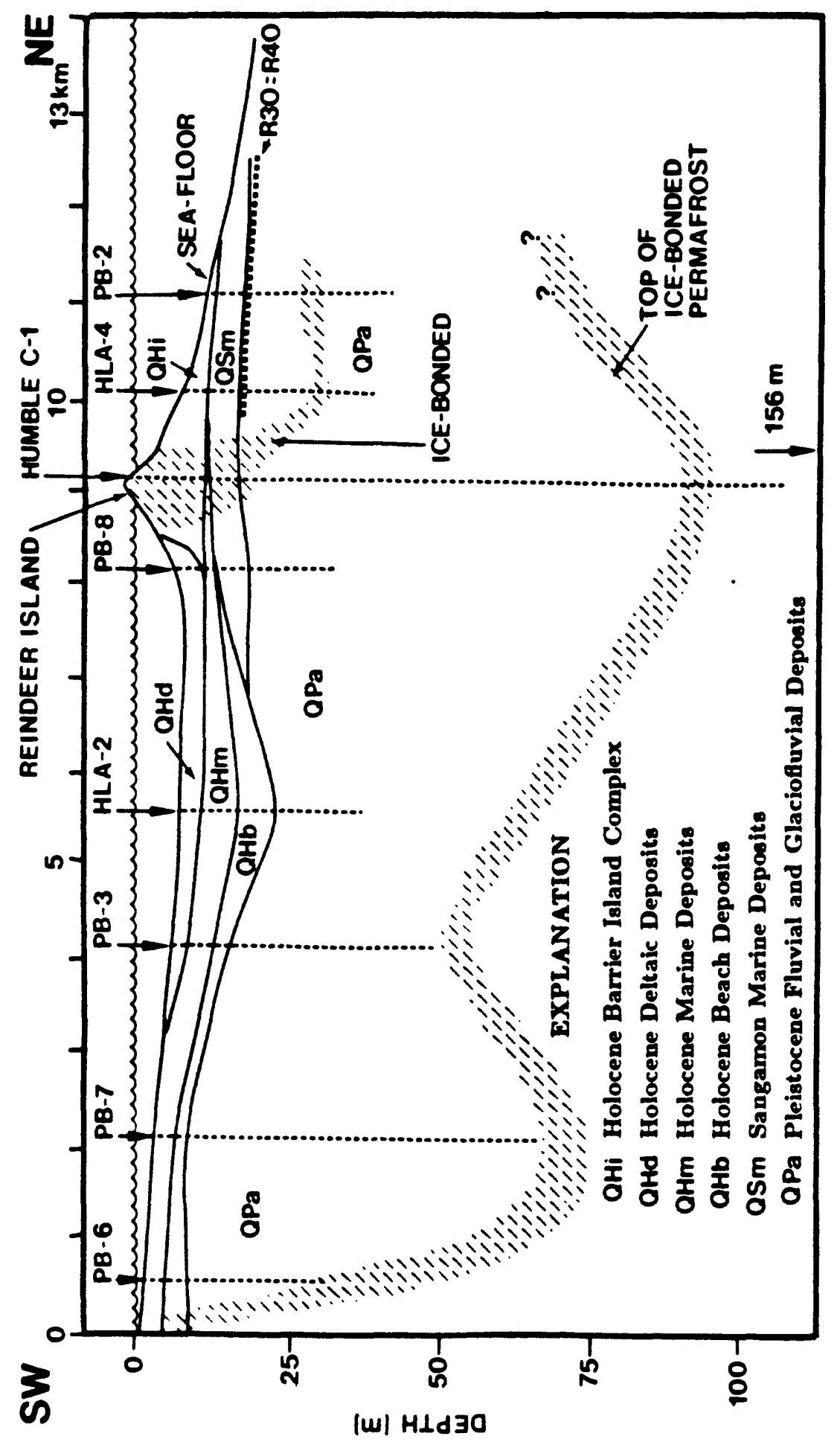

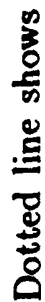

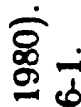

ส

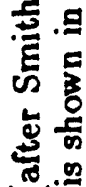

을 융

过

岂

8

응

อิ

\&.

0 를

$\approx$

틍

L

鸟

号

응

ㅇํㅇ

i

b

$\sum_{i=1}^{0}$ 
reflectors are evident in the interpretation of $\mathrm{R} 50$ and deeper reflectors in Cross-section A (Plate 1). These landward dipping reflectors may represent the seaward flank of the paleovalley. Boreholes indicate the seaward flank where Pleistocene marine sediments were not excavated during the formation of the paleovalley. North of Reindeer Island, Pleistocene Sangamon marine sediments mantle the Pleistocene fluvial unit (Figure 6-2). A continuous R30 $=\mathrm{R40}$ is correlated to borehole PB-2 north of Reindeer Island (Figure 11-18). The same reflector is not as well defined in the acoustic profile that is tied to borehole HLA-4. An offset in correlation with borehole HLA-4 may be due to the distance of the borehole from the acoustic profile. Based on the position of $R 30=R 40$, Sequence $B$ in this region correlates to Sangamon marine deposits, and Sequence D corresponds to Pleistocene fluvial sand and gravel. Sequence $\mathbf{E}$ is likely to occur below Sequence D, but is undifferentiated from Sequence $D$ in the acoustic and borehole data.

Two boreholes offset from the borehole transect (Hartz et al., 1979) are correlated to the acoustic stratigraphy. Borehole HLA-3 has less than $1 \mathrm{~m}$ each of Holocene marine and Flaxman Member deposits (Hartz et al., 1979). These deposits overlie Sangamon marine sediments that grade into Middle Pleistocene gravel outwash. Sequences A and B are absent on the acoustic profile that is correlated with borehole HLA-3 (Figure 11-15). Presumably, Flaxman and Holocene marine deposits are too thin to resolve on the acoustic profiles. The lower gradational contact of Sangamon marine sediments may not reflect an acoustic signal. The above evidence suggests that no paleovalley (Hopkins et al., 1979) exists at boreholes HLA-3, HLA-4, and PB-2.

In borehole HLA-5, Sequence A corresponds to Holocene marine silt and clay, and Sequence $B$ is equal to Holocene beach deposits (Figure 11-17) (Hartz et al., 1979). The interpretation of Sequence B in the acoustic profile tied to borehole HLA-5 is not consistent with Sequence B lithologies found in other boreholes. The contrast in lithology and the presence of a trough makes the correlation to Sequence B suspect. The top of Sequence $E$ correlates to Late Wisconsin outwash (Figure 11-17). Borehole HLA-5 supports the extension of the paleovalley trough west from the borehole transect (Figure 6-2). The seaward flank of the trough is seen in an acoustic profile (Line 13-72) (Plate 1, Crosssection A). A westward or seaward extension of the trough, beyond borehole HLA-5 and Line 13-72, could not be confirmed with the existing data. It is possible that the paleovalley turned seaward between boreholes HLA-5 and HLA-3. The lack of trough in a boomer profile (Line 21-72) suggests the paleovalley did not extend east of borehole HLA-5.

\subsection{Correlation of Acoustic Stratigraphy to Onshore Stratigraphy}

The stratigraphy of gravel pits between the Colville and Kuparuk Rivers (Rawlinson, 1986) is correlated to offshore borehole and acoustic stratigraphy. Rawlinson (1986) suggested a northward thinning fluvial or glaciofluyial fan (Ugnuravik gravel) is deposited on the coastal plain (Figure 2-1). He indicated that between $1.5 \mathrm{~m}$ and $1.9 \mathrm{~m}$ of eolian sand (Ugnuravik sand) is deposited above the Ugnuravik gravel. About $0.5 \mathrm{~m}$ of lacustrine peat overlies Ugnuravik Sand. I extended this onshore stratigraphy to a transect of boreholes that were used in constructing Cross-section B (Plate 2). The resulting transect (Figure 6-3) indicates the likely correlation of Ugnuravik gravel to Sequence E. Presumably, Sequence $\mathbf{E}$ is an offshore extension of the onshore fluvial and glaciofluvial fan.

\subsection{Chronostratigraphy}

An attempt was made to organize the acoustic stratigraphy, offshore borehole stratigraphy, and onshore stratigraphy on a Quaternary geologic time scale (Table 6-2). The chronology of marine transgressions on the Arctic Coastal Plain have been established 


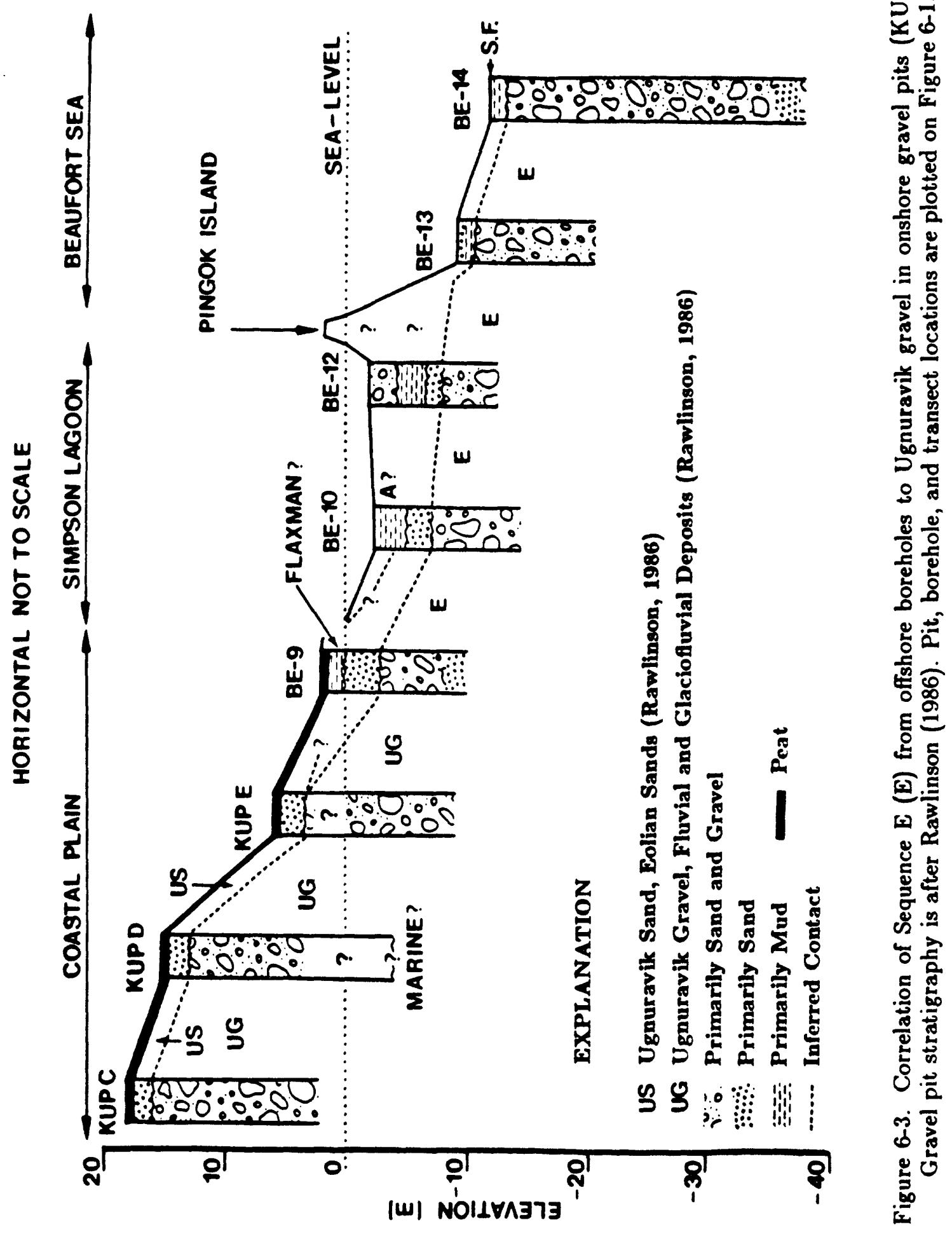




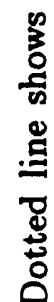

$\frac{5}{2}$

졍

نั

.

4

몽.

产

ฆึ้

뉸용

응

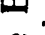

ह

등

薷

웅

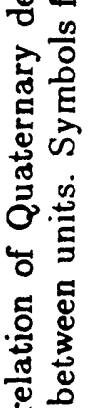

ชัㅇำ

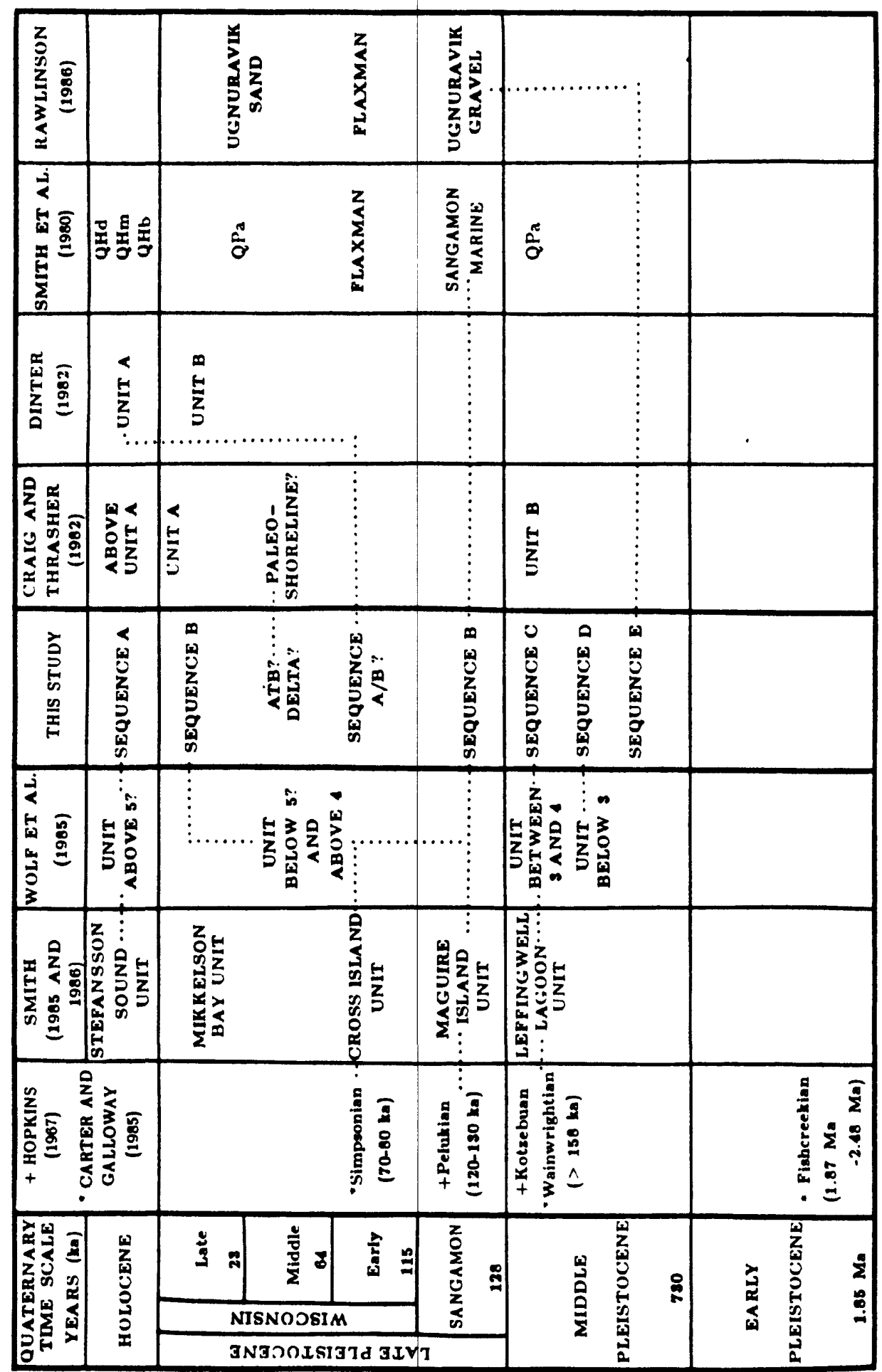

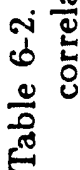


using thermoluminesence (TL) and amino-acid dating methods (Hopkins, 1967; Carter and Galloway, 1985; Brigham, 1985; Carter et al., 1986).

The chronology based on offshore acoustic stratigraphy (Craig and Thrasher, 1982; Dinter, 1982) is also shown in Table 6-2. These inferred ages have not been confirmed by dating.

The ages of my Sequences B, C, and D were based primarily on correlation to offshore borehole stratigraphy (Smith, 1985). Smith (1985) bases this chronologic interpretation (Table 6-2) on amino-acid dating, sediment texture, and biostratigraphy. The acoustic stratigraphy of Wolf et al. (1985) provides the link that makes correlations to the boreholes possible.

The borehole chronostratigraphy of Hartz et al. (1979) and Smith et al. (1980) correlates Sangamon marine deposits with the lower part of Sequence B. Sangamon marine sediments are equal to the Maguire Island Unit (Smith, 1985). The Flaxman Member correlates with the upper part of Sequence B and Smith's (1985) Cross Island Unit. The Holocene marine sediments also fit well with Sequence A. Middle Pleistocene gravels that correlate with Sequence D fit better with Sequence E's depositional environment. The interpretation of Sequence $D$ in the vicinity of the boreholes may be incorrect as Sequence $D$ may pinch out above Sequence $E$. Sequence $E$ in borehole HLA-5 corresponds to Late Wisconsin paleovalley fill. This age is much younger than the age suggested for Sequence E from the the onshore correlation to Ugnuravik gravel.

Ugnuravik gravel may be deposited over Fishcreekian marine transgressive deposits of the Harrison Bay Quadrangle (Section 2.1). Since Sequence E correlates to Ugnuravik gravel, Sequence $\mathrm{E}$ is probably not older than Fishcreekian transgressive deposits (1.9 Ma to $2.5 \mathrm{Ma}$ ) (Carter and Galloway, 1985). An older minimum age than Rawlinson's (1986) TL dates $(150,200 \pm 11,000$ years and $221,400 \pm 17,000$ years B.P.) of Ugnuravik gravel is suggested for Sequence $E$ (Table 6-2). On the inner shelf, Sequence D onlaps Sequence E. If my correlation of Sequence $E$ to Ugnuravik Gravel is correct then a minimum age older than Sequence D (Middle Pleistocene) is expected. The age suggested for Sequence $E$ (Table 6-2) is consistent with older ages $(1.7-2.4 \mathrm{Ma}$ ) suggested for Ugnuravik gravel based on the presence of fossil wood (larch) within Ugnuravik gravel deposits (D.M. Hopkins and S.E. Rawlinson, personal communication, 1987).

\subsection{Sea-level History}

The results of this study were compared to an existing local (Beringian) Quaternary sea-level curve (Figure 6-4) (Hopkins, 1982). This curve is plotted from data of the Bering, Chukchi, and Beaufort Seas and coasts after Hopkins (1973), Hartz et al. (1979), Hopkins et al. (1981), and McManus et al. (1982).

${ }^{14} \mathrm{C}$ age-depth relations of two borehole samples (Section 5.2 ) are compared to the Holocene part of the Beringian sea-level curve (Figure 6-4). A dated detrital peat from borehole HLA-12/82 is plotted on the Beringian curve (Figure 6-4). A single marine gastropod from a sample $30 \mathrm{~cm}$ below the peat suggests that the peat was deposited close to a former sea-level. Such a deposit is expected to plot close to the sea-level curve. The age-depth position is significant, because it suggests that the overlying R50 (Figure 5-15) relates to a Holocene transgressive surface. The influence of tectonism on the sample depth should be negligible in this region (Biswas and Gedney, 1979; Grantz et al., 1983). Possible subsidence due to thawing of subsea permafrost may have displaced the sample depth. Based on a comparison to borehole EBA-8, ice-bonded sediments may be within 4 $\mathrm{m}$ below the dated sample. However, the fine grained deltaic and marine sediments above 


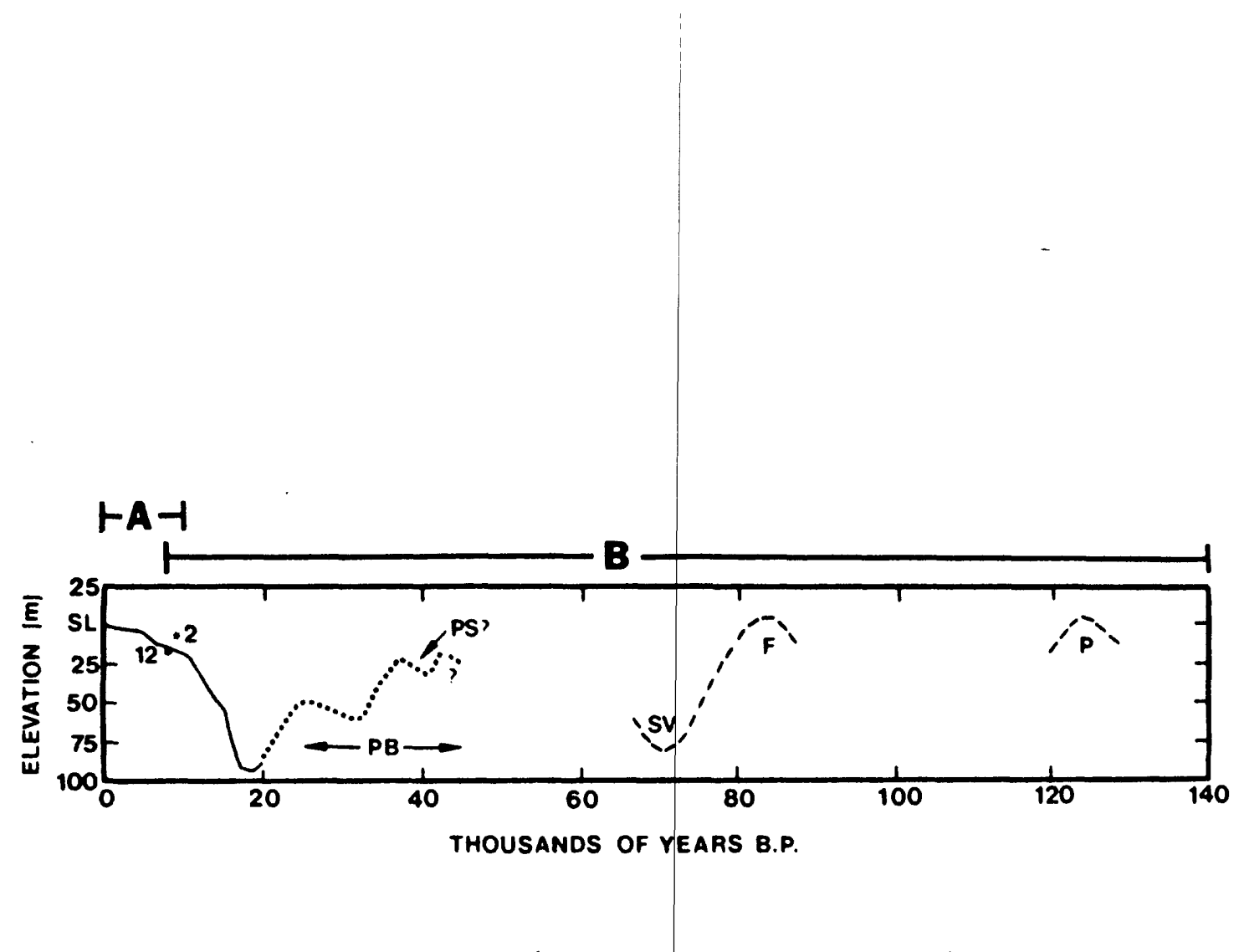

Figure 6-4. Beringian sea-level curve (modified from Hopkins, 1982). The curve younger than 20,000 years is after Hopkins (1973) and McManus et al. (1982). The dotted (PB) curve is inferred from ${ }^{14} \mathrm{C}$ dated onshore and offshore stratigraphy in Prudhoe Bay (Hartz et al., 1979; Hopkins et al., 1981). SV pertains to sea-level lowstands when valleys were excavated near Prudhoe Bay (Hopkins et al., 1979). F shows the transgressive peak in which the Flaxman Member was deposited (Hopkins, 1979). $\mathbf{P}$ is the peak of the Pelukian transgression in which Sangamon marine sediments were deposited (Hopkins, 1967). The suggested age ranges for Sequences $A$ and $B$ are shown above. Age-depth relationships of ${ }^{14} \mathrm{C}$ dated samples from boreholes HLA-2/82 (*2) and HLA-12/82 (*12) are plotted. PS? is the inferred age of the paleoshoreline and paleodelta sequence that represents a sea-level stillstand at $21 \mathrm{~m}$ below present sea-level. 
the ice-bonded layer is not ice-bearing. Thaw settlement is probably insignificant if the underlying ice-bonded layer is relict permafrost. Reimnitz et al. (1985) concluded that thaw settlement is less important in lowering the sea-floor elevation compared to sea-floor erosion. They suggested a maximum thaw settlement of less than $1.5 \mathrm{~m}$ for a transect west of Harrison Bay. The age-depth relation of a sample from borehole HLA-2/82 is also plotted on the Beringian sea-level curve. This peat deposit is interpreted as a coastal plain deposit that had accumulated at an elevation up to $15 \mathrm{~m}$ above a former sea-level and has since been buried below sea-level. Deposition above sea-level seems likely, because the dated sample plots above the sea-level curve (Figure 6-4).

The inferred paleoshoreline (Craig and Thrasher, 1982), ATB, and buried deltaic sequence (Figures 5-8 and 5-11) are compared to the Beringian sea-level curve (Figure 6-4). The interpretations are speculative since the shoreline and delta are not dated. The delta sequence may have been deposited the same time as other buried deltas on the Beaufort shelf, about 36,000 years B.P. (Dinter, 1985). A series of sea-level peaks that are below present sea-level occurred during Hopkins's (1982) Boutelier interval from 60,000 to 28,000 years ago (Figure 6-4). Samples from offshore boreholes and gravel pits on the coastal plain were dated with ${ }^{14} \mathrm{C}$ (Hartz et al., 1979; Hopkins et al., 1981) and interpreted to construct the sea-level curve between 45,000 and 20,000 years B.P. (Hopkins, 1982). Middle Pleistocene sea-level is shown to peak below present sea-level in sea-level curves from the North American Atlantic and Gulf of Mexico cossts (Curray, 1965; Milliman and Emery, 1968; Dillion and Oldale, 1979). Craig and Thrasher (1982) put the Harrison Bay paleoshoreline depth at $33 \mathrm{~m} \pm 2 \mathrm{~m}$ below present sea-level, based on their interpretation of the base of a buried bluff as the former beach. I place the shoreline at $21 \mathrm{~m}$ below present sea-level based on depths to buried distributary channels; the top of the "bluff" is actually the top of the permafrost table which is preserved near the paleo sea-level depth. Different interpretation of the same shoreline results in a sea-level that is $10 \mathrm{~m}$ higher than Craig and Thrasher (1982) indicate. The shoreline elevation and tentative age is plotted on the Beringian curve (Figure 6-4). A buried delta offshore of Nome, on the Bering Sea shelf, records a former sea-level at $20 \mathrm{~m}$ below present sea-level (Moore, 1964) and may be of Middle Wisconsin age (Hopkins, 1973) or older (Hopkins, 1982). Although a Holocene age of the Colville River paleodelta could not be ruled out, the delta was most likely deposited during a Middle Wisconsin stillstand. Sea-level must have remained relatively constant for several thousand years for the paleodelta sequence to develop. Sea-level curves indicate that the Holocene transgression rose rapidly $(8 \mathrm{~mm} / \mathrm{yr})$ until sea-level reached $10 \mathrm{~m}$ below the present sea-level; then the transgression rate slowed to $1.4 \mathrm{~mm} / \mathrm{yr}$ (Nelson and Bray, 1970; Kennett, 1982, p.270). The rapid Holocene transgression past the paleoshoreline depth probably would not have allowed for an extensive delta sequence to be deposited.

The existing acoustic stratigraphy does not significantly add to the existing sealevel interpretations. Sequences $A$ and $B$ are shown in relation to the Beringian sea-level curve (Figure 6-4). Sequences C, D, and E are older than the sea-level curve. Elevations of unconformity (reflector) pinch outs on the inner Beaufort Sea shelf are not likely to represent maximum sea-level highstands. Where Sequence $C$ subcrops on the inner shelf (Plates 1 and 2, Cross-sections A and B) is clearly not the maximum elevation of the transgressive deposit, assuming the correlation of Sequence $C$ to deposits on the Arctic Coastal Plain is correct. Sediment bypassed the subaerially exposed shelf during sea-level lowstands, and some of the acoustic sequences, such as Sequence C, were eroded (Vail et al., 1977). Measuring the elevation of the reflector pinch out would give an inaccurate estimate of maximum sea-level highstand. Minimum Quaternary sea-level lowstands should be recorded on acoustic profiles on the outer shelf (Dinter, 1985). Because most of the data 
I interpreted are on the inner shelf, minimum sea-level lowstands are not observed in the acoustic stratigraphy.

\subsection{Synthesis of Quaternary Depositional History}

Sometime after the Fishcreekian transgression (1.9 $\mathrm{Ma}$ to $2.5 \mathrm{Ma}$ ) a fluvial and glaciofluvial system deposited sand and gravel on the coastal plain (Ugnuravik gravel) and on the present inner Beaufort shelf (Sequence E). The inner shelf was probably subaerially exposed during Sequence $\mathbf{E}$ deposition. Fluvial processes deposited gravel and eroded older marine sequences. Sea-level was lower than the present, and fluvial channels may have been cut into the surface of Sequence $E$ near the end of the deposition of Sequence E. Possibly, these paleochannels are younger than indicated here.

Sea-level rose in the middle Pleistocene and eventually transgressed Sequence E. Much of the unconformity at the surface of Sequence $\mathrm{E}$ was reworked and eroded as the shoreline transgressed fluvial deposits. This reworked unconformity was observed as R20 in the acoustic profiles. Primarily marine sediments (Sequence D) were deposited over the R20 unconformity. Sea-level subsided in the Middle Pleistocene. Fluvial influx was probably low compared to the deposition of Sequence E. Another major unconformity (R30) formed at the upper boundary of Sequence D during the sea-level lowstand.

A depostional sequence similar to Sequence $D$ was deposited sometime before 158,000 years B.P (Middle Pleistocene). Sea-level transgressed Sequence D and beveled the R30 unconformity and part of Sequence D. On the inner shelf Sequence D may have corresponded to reworked gravels beneath $\mathrm{R} 30=\mathrm{R} 40$. This sea-level rise, possibly the Wainwrightian(?) transgression, extended on to the coastal plain and deposited sediment up to an altitude of $20 \mathrm{~m}$ (Carter and Galloway, 1985). Then sea-level is believed to have dropped, and another unconformity (R40) formed at the surface of Sequence C. Erosion on the inner shelf removed some of Sequences C, D, and E and unconformities. Where the $\mathrm{R} 40$ unconformity cut into $\mathrm{R} 30$ that resulted in one reflector $(\mathrm{R} 30=\mathrm{R} 40)$ that represented two erosional events. R40 may have eroded some of Sequence $E$ and R20, thus one surface $(\mathrm{R} 20=\mathrm{R} 30=\mathrm{R} 40)$ represents three erosional events.

The Pelukian transgression probably peaked sometime during the Sangamon Stage of the Late Pleistocene. This transgression beveled the R20, R40, and R30 $=\mathrm{R} 40$ unconformities while forming the basal transgressive surface of Sequence B. Sangamon marine transgressive sediments were deposited on the inner shelf and coastal plain to a maximum altitude of $10 \mathrm{~m}$ (Carter and Galloway, 1985). A lowering of sea-level following the Pelukian transgression may have eroded Sangamon marine sediments on the inner shelf.

The Flaxman Member was deposited during the Simpsonian transgression to an altitude of $7 \mathrm{~m}$ (McCarthy, 1958; Hopkins, 1982). This was the second transgressive deposit within Sequence B. On the inner shelf, the Flaxman Member overlies Sangamon marine sediments north of Prudhoe Bay. Probable lag deposits of the Flaxman Member are evident as boulder patches on the inner shelf (Reimnitz and Ross, 1982). An unconformity was not observed where Flaxman Member deposits overlie Sangamon marine sediments. Sangamon and Flaxman transgressive deposits were undifferentiated in the acoustic profiles, as an unconformity was not evident within Sequence B. Ice gouging may have reworked the unconformity on the inner shelf, or the Simpsonian transgression was so rapid that a basal transgressive surface did not form (D.M. Hopkins, personal communication, 1988). R45 could have represented the base of the Flaxman Member as this unconformity was the first major unconformity to overlie Sequence B and R40 on the outer shelf. However, thick deposits of Sequence A/B were unlikely deposited during the brief Simpsonian 
transgression (D.M. Hopkins, personal communication, 1988).

During a fall in sea-level, after the deposition of the Flaxman Member and before 42,000 years B.P. (Hopkins, 1982), broad valleys were cut into the inner shelf near Prudhoe Bay (Hopkins, et al., 1979). The marine sediments of Sequence B, including Flaxman Member and Sangamon sediments, were partially removed at this time.

Sea-level transgressed the inner shelf sometime during the Middle Wisconsin. Paleovalleys were backfilled in the Prudhoe Bay region (Smith et al., 1980). An embayment may have existed in what is now part of Harrison Bay. The embayment was filled with prograding deltaic deposits, possibly from the Colville River. Sea-level appeared to have peaked at $21 \mathrm{~m}$ below the present sea-level as indicated by buried distributary channels. Much of the Harrison Bay region remained subaerially exposed, thus permafrost was able to aggrade within Sequence B deposits on the landward side of the ATB. Weller Bank may also have been subaerially exposed at this time.

Sea-level dropped during the end of the Wisconsin. Sediments were bypassed across the inner shelf and parts of Sequence B were eroded. Some of the paleochannels that cut into the surface of Sequence B may have formed during this sea-level lowstand.

Sea-level began to rise near the end of the Wisconsin and continues to rise in the Holocene. R50 seems to relate to the basal transgressive surface of the Holocene. R50 may have corresponded to an overconsolidated mud horizon that formed either subaerially or in shallow $(<2 \mathrm{~m})$ water by alternate freezing and thawing. The R50 interface correlated to a lithologic interface at the basal transgressive surface where R50 had transgressed coarse grained deposits. Holocene marine deposits, up to $6 \mathrm{~m}$ thick, were deposited where R50 was well defined in eastern Harrison Bay. The likely source of these sediments was from the Colville River. Holocene marine sediments were also deposited landward of barrier islands in the Prudhoe Bay and Stefansson Sound. The extent and thickness of Holocene deposition was less clear where R50 is not well defined. Holocene marine sediments may have been mixed with older sediments by ice gouging and strudel scouring. The construction and migration of Stamukhi Shoal likely began sometime after the onset of the Holocene transgression. Stamukhi Shoal appears to have migrated landward over R50 causing the deposition of reworked sediment over Sequence $A$.

\section{CONCLUSIONS AND RECOMMENDATIONS}

The acoustic stratigraphic framework defined a regressive (fluvial) depositional sequence that was onlapped by at least five transgressive sequences. Transgressive sequences dipped offshore and wedged out on the inner shelf. Reflectors also outcropped or subcropped on the inner shelf. Holocene marine sediments were thin to absent on the inner shelf. The lack of preservation of Holocene transgressive deposits and preservation of older transgressions presented a paradox. Ice gouging may account for the absence of Sequence $A$, or the rapid rate of the early Holocene transgression prevented the formation of a basal reflector. After the deposition of Sequence E, regressive deposits were not preserved between transgressive events, except for the upper part of Sequence B. A better understanding of Quaternary climate, occurrence of sea-ice in the past, and paleobathymetry may provide more insight to unanswered questions.

Tentative ages were assigned to older acoustic sequences based on correlation to previous work. ${ }^{14} \mathrm{C}$ analysis from this study verified Holocene marine deposits.

Glacioeustatic seo-level fluctuations were the primary control on sequence deposition. Deposition was low between transgressions, except Sequence E and the upper part of 
Sequence B. A Middle Wisconsin(?) stillstand was well preserved within Sequence B.

Reflectors on the acoustic profiles were confirmed to be caused by subsea permafrost with borehole stratigraphy. The distribution of a discontinuous partially-bonded horizon appeared to be controlled by the embayment and paleoshoreline of the Middle Wisconsin(?) stillstand in Harrison Bay.

Gas-bearing horizons and attenuated zones were assumed to occur based on the acoustic character of the reflectors. Some of the gas-bearing sediments appeared to be associated with apparent fault planes and the paleodelta sequence.

This thesis has provided a stratigraphic framework that would be useful for planning more detailed studies. Several problems exist. The chronostratigraphic significance of a large volume of sediment on the outer shelf, Sequence A/B, is uncertain. Queried reflectors in the western part of the study area should be correlated to reflectors in the east. Additional information on the depositional environments of the acoustic sequences is needed. The nature of sequence boundaries such as R50 are not well understood. Boreholes for paleostratigraphic and geotechnical studies could be located based on the acoustic stratigraphy. Borehole studies could improve knowledge of the acoustic sequences with dating, biostratigraphy, and textural methods. Additional acoustic profiles could fill in data gaps so reflectors could be correlated. The acoustic stratigraphy may be improved by using a variety of acoustic sources and processing the data over different frequency bands. 


\section{REFERENCES}

Barnes, P.W., Asbury, J.L., Rearic, D.M., and Ross, C.R., 1987, Ice erosion of a sea-floor knickpoint at the inner edge of the stamukhi zone, Beaufort Sea, Alaska: Marine Geology, v. 76, p. 207-222.

Barnes, P.W., Rearic, D.M., and Reimnitz, Erk, 1984, Ice gouging characteristics and processes, in Barnes, P.W., Schell, D.M., and Reimnitz, Erk, eds., The Alaskan Beaufort Sea: ecosystems and environments: New York, Academic Press, Inc., p. 185-212.

Barnes, P.W., and Reimnitz, Erk, 1972, River overflow into sea ice off the northern coast of Alaska, Spring 1972: EOS, Transactions American Geophysical Union, v. 53, p. 1020.

- 1973, The shorefast ice cover and its influence on the currents and sediments along the coast of northern Alaska: EOS, Transactions American Geophysical Union, v.54, p. 1108.

- 1974, Sedimentary processes on Arctic shelves off the northern coast of Alaska, in Reed, J.C., and Sater, J.E., eds., The coast and shelf of the Beaufort Sea, Proceedings of a Symposium on Beaufort Sea Coast and Shelf Research: Arlington, Virginia, Arctic Institute of North America, p. 439-476.

- 1979, Ice gouge obliteration and sediment redistribution event, 1977-1978, Beaufort Sea, Alaska: U.S. Geological Survey Open-File Report 79-848.

Barnes, P.W., Reimnitz, Erk, Drake, D.E., and Toimil, L.J., 1977, Marine environmental problems in the ice-covered Beaufort Sea and coastal regions, in National Oceanic and Atmospheric Administration, Environmental Assessment of the Alaskan Continental Shelf: Annual Reports of Principle Investigators March 1977, v. 12 p. 1-129.

Barnes, P.W., and Reiss, T., 1981, Geological comparison of two Arctic shoals, Unpublished annual report to U.S. Department of Commerce and U.S. Department of the Interior (OCSEAP), Juneau, Alaska.

Barnes, P.W., Ross. C.R., and Reimnitz, Erk, 1981, Break in gouge character related to ice ridges, in National Oceanic and Atmospheric Administration, Environmental Assessment of the Alaskan Continental Shelf: Annual Reports of Principle Investigators March 1981, v. 9, p. 33-343.

Benton Engineering, Inc., 1970, Soils investigation: oil storage and distribution facilities, North Slope, Point Storkerson to Milne Point, Beaufort Sea, Alaska: Unpublished report submitted to Marine Advisors, Inc. and Hamilton Brothers Oil Company, $65 \mathrm{p}$.

Biswas, N.N., and Gedney, L., 1979, Seismotectonic studies of northern and western Alaska, in National Oceanic and Atmospheric Administration, Outer Continental Shelf Environmental Assessment Program: Annual Reports of Principle Investigators March 1979, v. 10, p. 155-208.

Black, R.F., 1964, Gubik Formation of Quaternary age in northern Alaska: U.S. Geological Survey Professional Paper 302-c. 91 p.

Blasco, S.M., 1983, A perspective on the distribution of subsea permafrost on the 
Canadian Beaufort continental shelf: Fourth International Conference on Permafrost, Final Proceedings, 17-22 July, 1983, Fairbanks, Alaska, p. 83-86.

Boucher, G., Reimnitz, Erk, and Kempema, E.W., 1980, Seismic evidence for an extensive gas-bearing layer at shallow depth, offshore from Prudhoe Bay, Alaska: U.S. Geological Survey Open-File Report 80-809, 20 p.

Briggs, S.R., 1983, Geology report for the proposed Beaufort Sea OCS sand and gravel lease sale, in Barnes, P.W., Reimnitz, E., Hunter, R.E., Phillips, R.L., and Wolf, S.C., eds., Geologic processes and hazards of the Beaufort and Chukchi shelf and coastal regions: National Oceanic and Atmospheric Administration, OCSEAP Final Report 1985 , v. 34, p. 21-83.

Brigham, J.K., 1985, Marine stratigraphy and amino acid geochronology of the Gubik Formation, western Arctic Coastal Plain, Alaska: Unpublished Ph.D. Dissertation, Dept. of Geological Sciences, University of Colorado, $316 \mathrm{p}$.

Cannon, P.J., and Rawlinson, S.E., 1981, Environmental geology and geomorphology of the barrier island-lagoon system along the Beaufort Sea coastal plain from Prudhoe Bay to the Colville River, in National Oceanic and Atmospheric Administration, Environmental Assessment of the Alaskan Continental Shelf: Final Report, v. 34(1985), p. 357-444, 15 map supplement.

Carter, L.D., Brigham-Grette, J.K., and Hopkins, D.M., 1986, Late Cenozoic marine transgressions of the Alaskan Arctic Coastal Plain and Beaufort Sea shelf, in Heginbottom, J.A., and Vincent, J.S., eds., Correlation of Quaternary deposits and events around the margin of the Beaufort Sea, Contributions from a joint Canadian-American workshop, April 1984: Geological Survey of Canada Open-File Report 1273, p. 21-26.

Carter, L.D., Forester, R.M., and Nelson, R.E., 1984, Mid Wisconsin through early Holocene changes in seasonal climate in northern Alaska: American Quaternary Association Eighth Biennial Meeting, Program with Abstracts, 13-15, August, 1984, p. $20-22$.

Carter, L.D., and Galloway, J.A., 1982, Terraces of the Colville River delta region, Alaska, in Coonrad, W.L., ed., The United States Geological Survey in Alaska: accomplishments during 1980: U.S. Geological Survey Circular 844, p. 49-51.

- 1985, Engineering-geologic maps of northern Alaska, Harrison Bay Quadrangle: U.S. Geological Survey Open-File Report 85-256, 47 p., 2 map sheets, scale 1:250,000.

Carter, L.D., and Robinson, S.W., 1978, Aeolian sand and interbedded organic horizons at Kaoluk Creek: regional implications: U.S. Geological Survey Open-File Report 78-320, 26 p.

Chamberlain, E.J., Sellmann, P.V., Blouin, S.E., Hopkins, D.M., and Lewellen, R.I., 1978, Engineering properties of subsea permafrost in the Prudhoe Bay region of the Beaufort Sea: Third International Conference on Permafrost, 10-13 July, 1978, Edmonton, Alberta, Canada, p. 630-635.

Collett, T.S., 1983, Detection and evaluation of natural gas hydrates from well logs, Prudhoe Bay, Alaska: Fourth International Conference on Permafrost, 17-22 July, 1983, Fairbanks, Alaska, p. 169-174.

Craig, J.D., and Thrasher, G.P., 1982, Environmental geology of Harrison Bay, northern 
Alaska: U.S. Geological Survey Open-File Report 82-35, 25 p.

Craig, J.D., Sherwood, K.W., and Johnson, P.P., 1985, Geologic report for the Beaufort Sea Planning Area, Alaska: regional geology, petroleum geology, environmental geology: United States Dept. of the Interior, Minerals Management Service OCS Report MMS 85-0111, 192 p.

Curray, J.R., 1965, Late Quaternary history continental shelves of the United States, in Wright, H.E., Jr., and Frey, D.G., eds., The Quaternary of the United States: Princeton, New Jersey, Princeton University Press, p. 723-725.

Dillon, W.P., and Oldale, R.N., 1979, Late Quaternary sea-level: reinterpretation based on glaciotectonic influence: Geology, v. 6, p. 56-60.

Dinter, D.A., 1982, Holocene marine sediments on the middle and outer continental shelf of the Beaufort Sea north of Alaska: U.S. Geological Survey Miscellaneous Investigations Series Map I-1182-B, scale 1:500,000.

- 1983, Quaternary sedimentation on the Alaskan Beaufort Sea shelf: sediment sources, glacioeustatism, and regional tectonics: U.S. Geological Survey Circular 911, p. 37-38.

- 1985, Quaternary sedimentation of the Alaskan Beaufort Sea shelf: influence of regional tectonics, fluctuating sea levels, and glacial sediment sources: Tectonophysics, v. 114, p. 133-161.

EBA Engineering Consultants Ltd. and McClelland Engineers, Inc., 1982, Geotechnical investigation of seabed soils: proposed Lease Sale Area OCS 71 Beaufort Sea, Alaska: Unpublished report submitted to SOHIO Petroleum Co., San Francisco, California.

Ewing, J., and Ewing, M., 1970, Seismic reflections, in Maxwell, A.E., ed., The sea: New York, Wiley-Interscience, v. 1, part 1, p. 1-52.

Grantz, A., Dinter, D.A., and Biswas, N.N., 1983. Map, cross sections, and chart showing late Quaternary faults, folds, and earthquake epicenters on the Alaskan Beaufort Sea shelf: U.S. Geological Survey Miscellaneous Investigation Series Map I-1182-C.

Grantz, A., Dinter, D.A., Hill, E.R., May, S.D., McMullin, R.H., and Phillips, R.L., 1982, Geologic framework, hydrocarbon potential and environmental conditions for exploration and development of proposed Lease Sale 87 in the Beaufort and northeast Chukchi Seas, a summary report: U.S. Geological Survey Open-File Report 82-482, $71 \mathrm{p}$.

Grantz, A., and Greenburg, J., 1981, Map showing tracklines of high-resolution uniboom seismic reflection profiles from the Beaufort Sea, 1977: U.S. Geological Survey OpenFile Report 81-34, 1 map, scale 1:1,000,000.

Harding-Lawson Associates, 1979, Geotechnical investigation of the Beaufort Sea: Available from the National Geophysical Data Center, Data Set AK 17718, 3 vols.

Hartz, R.W., Holden, K., Hopkins, D.M., and Shearer, G., 1979, Location map and summary loge for the U.S. Geological Survey's 1979, Beaufort Sea over the ice drilling program: U.S. Geological Survey Open-File Report 79-1303, 33 p.

Hayes, M.O., 1979, Barrier island morphology as a function of tidal and wave regime, in Leatherman, S.P., ed., Barrier islands from the Gulf of St. Lawrence to the Gulf of Mexico: New York, Academic Press, p. 1-63. 
Hopkins, D.M., 1967, Quaternary marine transgressions in Alaska, in Hopkins, D.M., ed., The Bering Land Bridge: Stanford, California, Stanford University Press, p. 91-120.

- 1973, Sea level history in Beringia during the last 250,000 years: Quaternary Research, v. 3, p. $520-540$.

- 1975, Time stratigraphic nomenclature for the Holocene Epoch: Geology, January, v. 3, p. 10.

- 1977, Offshore permafrost studies, Beaufort Sea, Alaska, in National Oceanic and Atmospheric Administration, Environmental Assessment of the Alaskan Continental Shelf: Annual Reports of Principle Investigators March 1977, v. 16, p. 396-518.

- 1979, The Flaxman Formation of northern Alaska: Record of early Wisconsin shelf glaciation in the high Arctic?, $14^{\text {th }}$ Pacific Science Congress, Abstracts, additional volume, Khabarovsk, p. 15-16.

- 1982, Aspects of the paleogeography of Beringia during the Late Pleistocene, in Hopkins, D.M., Matthews, J.V., Schweger, C.E, and Young S.B., eds., Paleoecology of Beringia: New York, Academic Press, p.3-28.

- 1987, Sand and gravel sources, in Becker, P.R., ed., Proceedings of a synthesis meeting, the diapir field environment and possible consequences of planned offshore oil and gas development, 25-28 January, 1983, Chena Hot Springs, Alaska, p. 67-71.

Hopkins, D.M., and Hartz, R.W., 1978a, Coastal morphology, coastal erosion, and barrier islands of the Beaufort Sea, Alaska: U.S. Geological Survey Open-File Report 78-1063, $54 \mathrm{p}$.

- 1978b, Offshore permafrost studies, Beaufort Sea, in National Oceanic and Atmospheric Administration, Environmental Assessment of the Alaskan Continental Shelf: Annual Reports of Principle Investigators March 1978, v. 11, p. 75-147.

Hopkins, D.M., Robinson, S.W., and Buckley, J., 1981, Radiocarbon dates from the Beaufort and Chukchi Sea coasts (1979-80), in National Oceanic and Atmospheric Administration, Environmental Assessment of the Alaskan Continental Shelf: Annual Reports of Principle Investigators, v. 5 (Hazards), p. 203-220.

Hopkins, D.M., Sellmann, P.V., Chamberlain, E., Lewellen, R.E., and Robinson, S.W., 1979 , Buried paleovalleys as a possible determinant of the distribution of deeply buried permafrost on the continental shelf of the Beaufort Sea, in National Oceanic and Atmospheric Administration, Environmental Assessment of the Alaskan Continental Shelf: Annual Reports of Principle Investigators March 1979, v. 11, p. 54-62.

Howitt, F., 1971, Permafrost geology at Prudhoe Bay: World Petroleum, v. 171, no. 4, p. 28-38.

Hunter, J.A., Good, R.L., and Hobson, G.D., 1974, Mapping the occurrence of subseabottom permafrost in the Beaufort Sea by shallow refraction techniques: Geological Survey of Canada Report of Activities Paper 74-1B, p. 91-94.

Kennett, J.P., 1982, Marine geology: Englewood Cliffs, New Jersey, Prentice-Hall Inc., p. 272.

Kovacs, A., 1976, Grounded ice in the fast ice zone along the Beaufort Sea coast of Alaska: U.S. Army, CRREL Report 76-32, 21 p. 
Kvenvolden, K.A., and McMenamin, M.A., 1980, Hydrates of natural gas: a review of their geologic occurrences: U.S. Geological Survey Circular 825, 11 p.

Lee, H.J., Winters, W.J., and Chamberlain, E.J., 1985, Geotechnical properties and freeze/thaw consolidation behavior of sediment from the Beaufort Sea, Alaska: U.S. Geological Survey Open-File Report 85-612, 83 p.

Leffingwell, E.K., 1919, The Canning River region, northern Alaska: U.S. Geological Survey Professional Paper 109, 251 p.

Lewellen, R.I., 1977, A study of Beaufort Sea coastal erosion, northern Alaska in National Oceanic and Atmospheric Administration, Environmental Assessment of the Alaskan Continental Shelf: Annual Reports of Principle Investigators March 1977, v. 15, p. 491-527.

Lunardini, V.J., 1981, Heat transfer in cold climates: New York, Van Nostrand Reinhold Co., 731 p.

Macleod, M.K., 1982, Gas hydrates in ocean bottom sediments: American Association of Petroleum Geologists Bulletin, v. 66, no. 12, p. 2649-2662.

McCarthy, G.R., 1958, Glacial boulders on the Arctic coast of Alaska: Arctic, v. 11, p. 71-85.

McCulloch, D.S., 1967, Quaternary geology of the Alaskan shore of the Chukchi Sea,in Hopkins, D.M., ed., The Bering Land Bridge: Stanford, California, Stanford University Press, p. 91-120.

McManus, D.A., Creager, J.S., Echols, R.J., and Holmes, M.J., (1982) The Holocene transgression on the arctic flank of Beringia: Chukchi valley to Chukchi estuary to Chukchi Sea, Symposium on Quaternary land-sea migration routes and human occupation of submerged coastlines, La Jolla, California.

McQuillian, R., Bacon, M., and Barclay, W., 1984, An introduction to seismic interpretation, reflection seismics in petroleum exploration: Houston, Texas, Gulf Publishing Company, 287 p.

Mead, R., and Brockett, B., 1982, Sediment and ground ice observations from geophysical shot holes, Spring, 1981, National Petroleum Reserve, Alaska: U.S. Army CRREL.

Milliman, J.D., and Emery, K.O., 1968, Sea levels during the past 35,000 years: Science, v. 162 , p. 1121-1123.

Mitchum, R.M., Jr., 1977, Glossary of terms used in seismic stratigraphy, in Payton, C.E., ed., Seismic stratigraphy - applications to hydrocarbon exploration: American Association of Petroleum Geologists Memoir 26, p. 205-212.

Mitchum, R.M., Jr., Vail, P.R., and Thompson, S., III, 1977, Seismic stratigraphy and global sea level, part 2: the depositional sequence as a basic unit for stratigraphic analysis, in Payton, C.E., ed., Seismic stratigraphy - applications to hydrocarbon exploration: American Association of Petroleum Geologists Memoir 26, p. 53-62.

Moore, D.G., 1964, Acoustic-reflection reconnaissance of continental shelves - eastern Bering and Chukchi Seas, in Miller, R.L., ed., Marine Geology, Shepard commemorative volume: New York, MacMillan, p. 319-362.

Morack, J.L. and Rogers, J.C., 1984, Acoustic velocities of nearshore materials in the 
Beaufort and Chukchi Seas, in Barnes, P.W., Schell, D.M., and Reimnitz, Erk, eds., The Alaskan Beaufort Sea ecosystems and environments: New York, Academic Press, p. 259-274.

Mowatt, T.C., and Naidu, A.S., 1974, Gravels from the Alaskan continental shelf, Beaufort Sea, Arctic Ocean: petrographic character and implications for sediment transport: Alaska Geological and Geophysical Survey Open-File Report AOF 43, 40 p.

Muller, S.W., 1947, Permafrost or permanently frozen ground and related engineering problems: U.S. Army Engineers, Military Intelligence Division Office, Special Report Stratigraphic Engineering Study Number 62, $231 \mathrm{p}$.

Naidu, A.S., 1974, Sedimentation on the Beaufort Sea: a synthesis, in Herman, Y., ed., Marine geology and oceanography of the Arctic seas: New York, Springer-Verlag, p. 173-190.

Naidu, A.S., and Mowatt, T.C., 1974, Aspects of size distribution, mineralogy, and geochemistry of deltaic and adjacent shallow marine sediments, north Arctic Alaska: University of Alaska, Institute of Marine Science Report R74-I, p. 145-208.

- 1975, Depositional environments and sediment characteristics of the Colville and adjacent deltas, northern Arctic Alaska, in Broussard, M.L., ed., Deltas, models for exploration: Houston, Texas, Houston Geological Society, p. 283-309.

National Geophysical Data Center, 1987, Catalog of marine geological and geophysical data, Beaufort Sea - EEZ: NOAA National Geophysical Data Center Data Announcement 87-MGG-13, 9 p.

Neave, G.K., Sellmann, P.V., and Delaney, A., 1981, Hyperbolic reflectors on Beaufort Sea seismic records: U.S. Army CRREL Report 81-2, 16 p.

Neave, G.K., and Sellmann, P.V., 1982, Subsea permafrost in Harrison Bay, Alaska, an interpretation from seismic data: CRREL Report 82-24, $62 \mathrm{p}$.

- 1984, Determining distribution patterns of ice-bonded permafrost in the United States Beaufort Sea from seismic data, in Barnes, P.W., Schell, D.M., and Reimnitz, Erk, eds., The Alaskan Beaufort Sea ecosystems and environments: New York, Academic Press, p. 237-258.

Nelson, H.F., and Bray, E.E., 1970, Stratigraphy and history of the Holocene sediments in the Sabine-High Island area, Gulf of Mexico, in Morgan, J.P. and Shaver, R.H., eds., Deltaic sedimentation modern and ancient: Tulsa, Oklahoma, Society of Economic Paleontologists and Mineralogists, Special Publication Number 15, p. 48-77.

Nijman, W., and Puigdefabregas, C., 1978, Coarse-grained point bar structure in a molasse type fluvial system, Eocene Castrisent Sandstone Formation, South Pyrenean Basin, in Miall, A.D., ed., Fluvial sedimentology: Canadian Society of Petroleum Geologists Memoir 5, p. 487-510.

O'Conner, M.J., 1977, Gas seeps, permafrost and acoustic voids in the southern Beaufort Sea: Symposium of Permafrost Geophysics, Saskatoon, Saskatchewan.

O'Conner, M.J., 1980, Development of a proposed geologic model to account for the surficial geology of the southern Beaufort Sea: Geological Survey of Canada Open-File Report 954, $128 \mathrm{p}$. 
O'Conner, M.J., 1981, Distribution of shallow permafrost a report on the southern Beaufort Sea: Geological Survey of Canada Open-File Report 953, 72 p.

Osterkamp, T.E., and Harrison, W.D., 1978a, Subsea permafrost-probing, thermal regime and data analysis, in National Oceanic and Atmospheric Administration, OCSEAP, Research Unit 253: Quarterly Reports of Principle Investigators for April-June 1978, p. 369-370.

- 1978b, Subsea permafrost-probing, thermal regime and data analysis, in National Oceanic and Atmospheric Administration, OCSEAP, Research Unit 253: Quarterly Reports of Principle Investigators for October-December 1978, p. 319-399.

- 1982, Subsea permafrost: probing, thermal regime and data analysis, in National Oceanic and Atmospheric Administration, Environmental Assessment of the Alaskan Continental Shelf: Annual Reports of Principle Investigators, 99 p.

Payne, T.G. et al., 1952, Geology of the Arctic slope of Alaska: U.S. Geological Survey Oil and Gas Inventory Map OM-126.

Rawlinson, S.E., 1986, Late Cenozoic geology of the Arctic Coastal Plain between the Colville and Canning Rivers, in Heginbottom, J.A., and Vincent, J.S., eds., Correlation of Quaternary deposits and events around the margin of the Beaufort Sea, Contributions from a joint Canadian-American workshop, April 1984: Geological Survey of Canada Open-File Report 1273, p. 31-33.

Rearic. D.M., Barnes, P.W., and Reimnitz, Erk, 1981, Ice gouge data, Beaufort Sea, Alaska. 1972-1980: U.S. Geological Survey Open-File Report 81-950, 8 microfiche cards.

Reimnitz, Erk, and Barnes, P.W., 1974, Sea ice as a geologic agent on the Beaufort Sea shelf of Alaska, in Reed, J.C., and Sater, J.E., eds., The coast and shelf of the Beaufort Sea, Proceedings of a Symposium on Beaufort Sea Coast and Shelf Research: Arlington, Virginia, Arctic Institute of North America, p. 301-353.

Reimnitz, Erk, Barnes, P.W., Rearic, D.M., Minkler, P.W., Kempema, E.W., and Reiss, T.E., 1982, Marine geologic investigations in the Beaufort Sea in 1981 and preliminary interpretations for regions from the Canning River to the Canadian border: U.S. Geological Survey Open-File Report 82-974, 66 p.

Reimnitz, Erk, and Bruder, K.F., 1972, River drainage into an ice-covered ocean and related sediment dispersal, Beaufort Sea, coast of Alaska: Geological Society of America Bulletin, v. 83, p. 861-866.

Reimnitz, Erk, Graves, S.M., and Barnes, P.W., 1985, Beaufort Sea coastal erosion, shoreline evolution, and sediment flux: U.S. Geological Survey Open-File Report 85-380, $70 \mathrm{p}$.

Reimnitz, Erk, Kempema, E.W., Ross, C.R., and Minkler, P.W., 1980, Overconsolidated surficial deposits on the Beaufort Sea shelf: U.S. Geological Survey Open-File Report 80-2010, 37 p.

Reimnitz, Erk, and Kempema, E.W., 1982, High rates of bedload transport measured from infilling rate of large strudel-scour craters in the Beaufort Sea, Alaska: U.S. Geological Survey Open-File Report 82-588, 18 p.

- 1984, Pack ice interaction with Stamukhi Shoal Beaufort Sea, Alaska, in Barnes, P.W., Schell, D.M., and Reimnitz, Erk, eds., The Alaskan Beaufort Sea ecosystems 
and environments: New York, Academic Press, p. 159-183.

Reimnitz, Erk, and Maurer, D.K., 1978, Stamukhi shoals of the Arctic - some observations from the Beaufort Sea: U.S. Geological Survey Open-File Report 78-666. 17 p.

Reimnitz, Erk, Maurer, D.K., and Barnes, P.W., 1977, Preliminary results of Kogru River studies, in National Oceanic and Atmospheric Administration, Environmental Assessment of the Alaskan Continental Shelf: Annual Reports of Principle Investigators March 1977, v. 17, p. 54-62.

Reimnitz, Erk, Rodeick, C.A., and Wolf, S.C., 1974, Strudel scour: a unique Arctic marine geologic phenomenon: Journal Sedimentary Petrology, v. 44, p. 409-420.

Reimnitz, Erk, and Ross, C.R., 1979, Lag deposits of boulders in Stefansson Sound, Beaufort Sea, Alaska: U.S. Geological Survey Open-File Report 79-1205, 26 p.

Reimnitz, Erk, Toimil, L.J., and Barnes, P.W., 1978, Arctic continental shelf morphology related to sea-ice zonation, Beaufort Sea, Alaska: Marine Geology, v.28, p. 179-210.

Reimnitz, Erk, Wolf, S.C., and Rodeick, C.A., 1972, Preliminary interpretation of seismic profiles in the Prudhoe Bay area, Beaufort Sea, Alaska: U.S. Geological Survey OpenFile Report 72-548, 11 p.

Ricker, N., 1953, Wavelet contraction, wavelet expansion and the control of seismic resolution: Geophysics, v. 18, p.769.

Rodeick, C.A., 1979, The origin, distribution and depositional history of gravel deposits on the Beaufort Sea continental shelf, Alaska: U.S. Geological Survey Open-File Report 79-234, 87 p.

Roethlisberger, H., 1972, Seismic exploration in cold regions: Science Engineering Monogr. II-A2a, U.S. Army CRREL, Hanover, New Hampshire.

Schrader, F.C., 1904, A reconnaissance of northern Alaska: U.S. Geological Survey Professional Paper 20, 139 p.

Sellmann, P.V., and Hopkins, D.M., 1983, Subsea permafrost distribution on the Alaskan shelf: Fourth International Conference on Permafrost, 18-22 July, 1983, Fairbanks, Alaska, p. 72-82.

Sieck, H.C., and Self, G.W., 1977, Analysis of high resolution seismic data, in Payton, C.E., ed., Seismic stratigraphy - applications to hydrocarbon exploration: American Association of Petroleum Geologists Memoir 26, p. 353-386.

Smith, P.A., 1985, Late Cenozoic stratigraphy of the Beaufort Sea inner shelf near Prudhoe Bay, Alaska: Fourteenth Arctic Workshop, Arctic Land-Sea Interaction, Abstracts, 6-8 November, 1985, Dartmouth, Nova Scotia, Canada, p. 25-28.

- 1986, The Late Pleistocene-Holocene stratigraphic record, Canning River Delta region, northern Alaska, in Heginbottom, J.A., and Vincent, J.S., eds., Correlation of Quaternary deposits and events around the margin of the Beaufort Sea, Contributions from a joint Canadian-American workshop, April 1984: Geological Survey of Canada Open-File Report 1273, p. 51-54.

Smith, P.A., Hartz, R.W., and Hopkins, D.M., 1980, Offshore permafrost studies and shoreline history as an aid to predicting offshore permafrost conditions, in National Oceanic and Atmospheric Administration, Environmental Assessment of the Alaskan 
Continental Shelf: Annual Reports of Principle Investigators March 1980, v. 4, p. 159-255.

Smith, P.A., and Hopkins, D.M., 1979, Offshore permafrost studies and shoreline history as an aid to predicting offshore permafrost conditions, in National Oceanic and Atmospheric Administration, Environmental Assessment of the Alaskan Continental Shelf: Annual Reports of Principle Investigators March 1979, v. 11, p. 116-163.

Stringer, W.J., 1978, Morphology of Beaufort, Chukchi and Bering Seas nearshore ice conditions by means of satellite and aerial remote sensing: Geophysical Institute, University of Alaska, Fairbanks, Alaska, v. 1, 218 p.

Sylwester, R.E., 1983, Single-channel, high-resolution, seismic-refiection profiling: a review of the fundamentals and instrumentation, in Handbook of Geophysical Exploration at Sea: CRC Press, p. 77-122.

U.S. Geological Survey, 1980, Lease Sale 71. U.S. Geological Survey (USGS) data set AK 19181: Available from the National Geophysical Data Center, Data Announcement 87-MGG-13, p. 3.

Vralsted, D.A., 1986, Delineation of shallow frozen sediment in Harrison Bay, Alaska: Unpublished M.S. Thesis, Geophysical Institute, University of Alaska-Fairbanks, $134 \mathrm{p}$.

Walker, H.J., 1974, The Colville River and the Beaufort Sea: some interactions, in Reed, J.C., and Sater, J.E., eds., The coast and shelf of the Beaufort Sea, Proceedings of a Symposium on Beaufort Sea Coast and Shelf Research: Arlington, Virginia, Arctic Institute of North America, p. 513-540.

Walker, R.G., and Cant, D.J., 1984, Sandy fluvial systems, in Walker, R.G., ed., Facies models, second addition: Geological Association of Canada, Geoscience Canada Reprint Series 1, p. 71-89.

Williams, J.R., Yeend, W.E., Carter, L.D., and Hamilton, T.D., 1977, Preliminary surficial deposits map of National Petroleum Reserve, Alaska: U.S. Geological Survey OpenFile Report 77-868, map scale 1:500,000.

Wolf, S.C., Reimnitz, Erk, and Barnes, P.W., 1985, Pleistocene and Holocene seismic stratigraphy between the Canning River and Prudhoe Bay, Beaufort Sea, Alaska: U.S. Geological Survey Open-File Report 85-549, 49 p.

Zubov, N.N., 1945, Arctic sea ice: (Translated by Naval Oceanographic Office and American Meteorological Society under contract to Air Force Cambridge Research Center, 1963), U.S. Naval Electronics Laboratory, San Diego, California, 491 p. 


\section{APPENDIX 1. PRINCIPLES OF HIGH-RESOLUTION ACOUSTIC REFLECTION PROFILING}

There are several reviews of the principles of high-resolution acoustic reflection profiling (Ewing and Ewing, 1970; Sieck and Self, 1977; Sylwester, 1983; McQuillin et al., 1984; Among Others). Sylwester (1983) summarizes the basic technique of high-resolution acoustic profiling:

The technique requires a ship with either a hull mounted or towed device that emits an acoustic pulse at regular intervals along a selected course or survey track (Figure 9-1). These acoustic pulses, when reflected from the sea-floor and underlying geology, are intercepted by a hydrophone that converts acoustic pressure waves into electric signals. Onboard the ship these electric signals are processed and displayed on a seismic-reflection recorder. This display, the seismic-reflection record, is an acoustical image of the sea-floor and sub-bottom structure along the survey track.

The remainder of this appendix summarizes the basic components and theory of highresolution acoustic reflection profiling.

\subsection{The Acoustic Source}

The acoustic source is selected based on the purpose of a particular survey. Highresolution acoustic sources emit a high frequency, low energy signal. The thickness of sub-bottom structures that can be resolved, and depth of penetration into the sub-bottom is controlled by the selection of the acoustic source. In general, resolution decreases with increasing depth penetration. The relationship of source frequency, depth penetration, and vertical resolution is illustrated in Figure 9-2.

Two acoustic sources, tuned transducers and boomers, were used to obtain data for this thesis. Tuned transducers, constructed from piezoelectric crystalline material, were operated at $3.5 \mathrm{kHz}$ and $7 \mathrm{kHz}$. These high frequency profiling systems provide good vertical resolution but low penetration of the sub-bottom. Boomer sources generate an acoustical pulse by the rapid motion of a plate against the water. The broad band frequency and high energy of boomer sources, compared to tuned transducers, provides good resolution and increased depth penetration.

\subsection{Acoustic Reflection Theory}

The transmitted acoustic signal is reflected at interfaces such as the sea-floor and sub-bottom horizons. The reflection is explained by an acoustical impedance $(Z)$ contrast at an interface. Some of the incident acoustic energy is reflected at the interface, and some energy is transmitted to deeper interfaces. The acoustical impedance of a medium is defined by the product of the compressional wave velocity $(C)$ and the bulk density of the medium $(\rho)$. The acoustical impedance contrast between two mediums defines the Rayleigh reflection coefficient $(R)$ which is a ratio of the reflected wave amplitude $\left(A_{r}\right)$ to the incident wave amplitude $\left(A_{i}\right)$. For a plane wave at normal incidence to an interface, the Rayleigh reflection coefficient may be expressed in terms of amplitudes or acoustical impedance $(Z)$ by

$$
R=\frac{A_{r}}{A_{i}}=\frac{Z_{2}-Z_{1}}{Z_{2}+Z_{1}}
$$




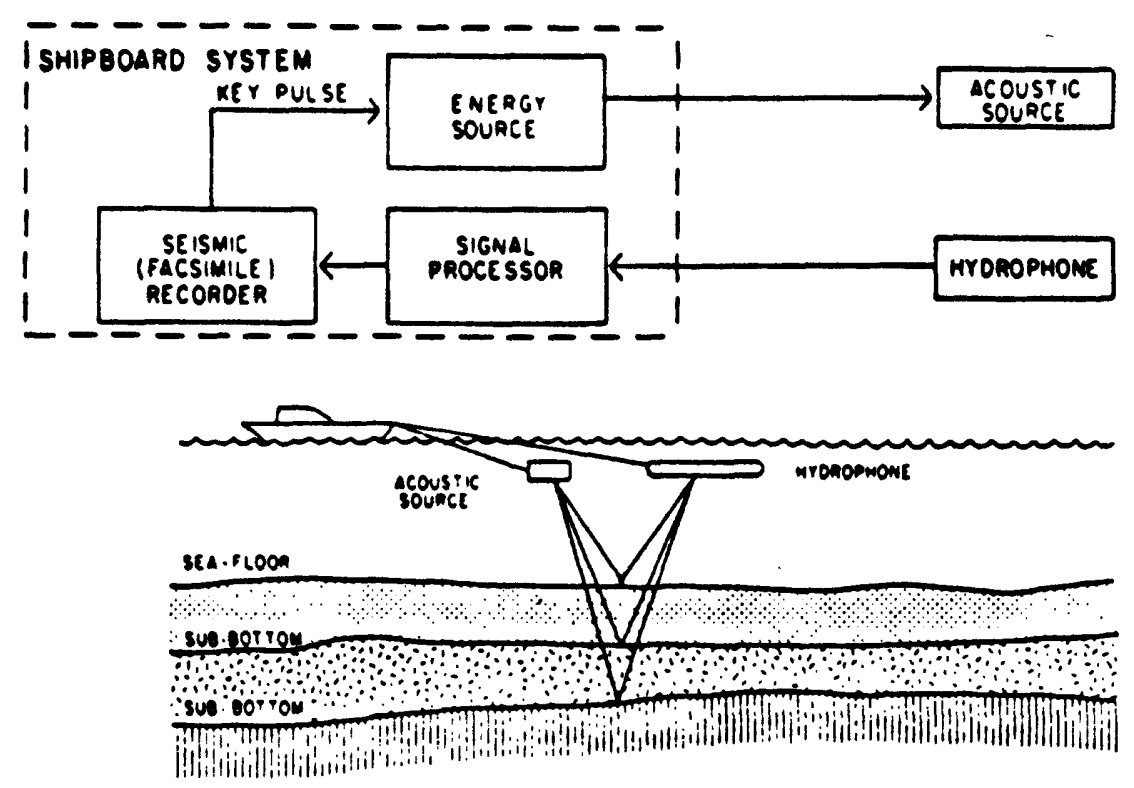

Figure 9-1. The basic components of continuous acoustic profiling (after Sylwester, 1983).

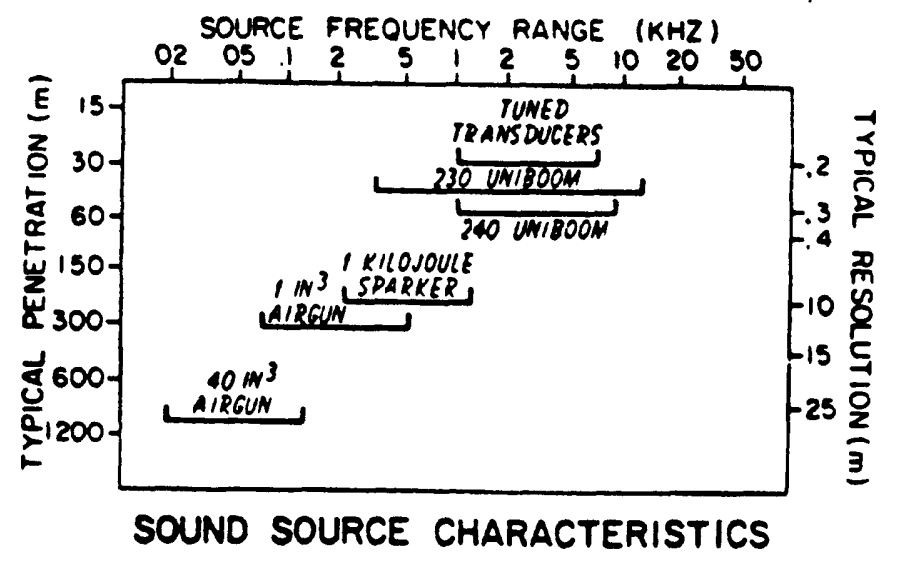

Figure 9-2. The relationship of acoustic source frequency to depth penetration, vertical resolution (after Sylwester, 1983). 
for an interface between mediums 1 and 2 with acoustical impedances $Z_{1}$ and $Z_{2}$

$$
\frac{M E D I U M_{1} \Longrightarrow Z_{1}=\rho_{1} C_{1}}{M E D I U M_{2} \Longrightarrow Z_{2}=\rho_{2} C_{2}} \Longleftarrow I N T E R F A C E
$$

The amount of acoustic energy that is transmitted through the interface is given by the relation

$$
R+T=1
$$

where $T$ is the transmission coefficient which can be expressed as

$$
T=1-R=\frac{2 Z_{1}}{Z_{1}+Z_{2}}
$$

The theoretical relationship of the reflection and transmission coefficients explains why less acoustic energy is transmitted below an interface when the reflection coefficient is large. Conversely, as the reflection coefficient decreases, transmission increases through the interface into the second medium. Eventually, as the acoustical impedances of the two mediums are equal, complete transmission of the acoustic signal through the interface will occur.

The theory of acoustic reflection is a good approximation that predicts if a reflection will occur and the strength of the reflection; however, spherical spreading, scattering from irregularities in the medium, angle of incidence, and attenuation of the acoustical wave all affect the amplitude of the reflected signal. Attenuation of the acoustic signal depends on the physical characteristics of the sediments and pore spaces. For example, sediment pore space that contains gas can attenuate the acoustic signal.

\subsection{Vertical Resolution}

The ability to detect units between interfaces in the sub-bottom depends on the vertical resolution capability of an acoustic profiling system. Sylwester (1983) summarizes the vertical resolution parameters. They are the sweep speed of the graphic recorder, signal to noise ratio, and characteristics of the acoustic source. The most important acoustic source parameters are pulse-length and dominant frequency or wavelength. The vertical resolution, thicknesses that can be detected between interfaces $(T)$, can be approximated (Ricker, 1953) as

where

$C=$ the compressional wave velocity

$f=$ the dominant frequency of the source

$\lambda=$ the dominant wavelength of the acoustic wave

For example, an acoustic signal with a dominant source frequency of $1 \mathrm{kHz}$ and a compressional wave velocity of $1600 \mathrm{~m} / \mathrm{s}$ will resolve a thickness $\geq 40 \mathrm{~cm}$, assuming that other parameters are optimum. 


\subsection{The Acoustic Receiver}

The return acoustic signal that has reflected from interfaces is detected by a hydrophone by converting acoustic pressure waves to an electrical signal. Piezoelectric sources have a dual function as the receiving hydrophone as well as an acoustic source. Boomer systems require a separate receiving hydrophone or hydrophone array. A hydrophone array is designed to optimize the detection of the signal.

The electrical signal produced by the hydrophone is modified by signal processors. The purpose of signal processors are two-fold. The electrical signal is filtered to remove ambient noise, and then the desired signal is amplified to enhance the reflection signal. Band-pass filters select a range of frequencies at a desired bandwidth. Manipulation of the bandwidth and frequency range can filter out or reduce ambient noise. Also, vertical resolution and penetration depth can be enhanced with band-pass filters. Centering the frequency spectrum at low frequencies improves depth penetration; however, vertical resolution decreases. A high frequency spectrum enhances vertical resolution but limits penetration. The received and filtered signal can be amplified with various gain controls. Manual gain controls can add a linear increase or decrease in reflector amplitude. Automatic gain control (AGC) decreases high amplitude reflections and increases the amplitude of weak reflectors. Time variable gain (TVG) can be used to increase the amplitude of reflectors with increasing two-way travel time (TWT), thus TVG enhances deeper reflectors in the sub-bottom.

\subsection{Recording the Acoustic Profile}

The filtered and amplified signal is recorded graphically or on magnetic tape. Graphic recording results in a continuous two-dimensional acoustic image of the sea-floor and underlying reflecting interfaces on a roll of chart paper. The chart paper is scaled along the horizontal and vertical axes.

The horizontal scale represents the time duration of profiling along the ships track. This is converted to distance by merging time fixes (navigation points) with the time measured on the chart paper. Both ship speed and the speed at which the chart paper advances affects the horizontal scale of the acoustic profile. The accuracy of the conversion of the horizontal scale to distance depends on the accuracy of fix points and the distance between fixes.

The vertical scale on the acoustic profile represents two-way travel time (TWT). TWT is the time for an acoustic signal to travel from the source (S) to the reflecting interface and back to the receiver (R) (Figure 93 ). The graphic recorder marks the TWT of a reflection on chart paper with a stylus that is attached to a continuous belt (Figure 9-4). The sweep rate is the time of one complete pass of the stylus across the chart paper. The sweep rate is adjusted 80 the desired length of TWT is scaled along the vertical axis of the chart paper. The stylus is keyed so that time zero TWT $\left(T_{0}\right)$ is at the top of the chart paper (Figure 9-4). Individual reflection events are then marked on the chart paper in descending TWT. Most of the acoustic profiles interpreted in this thesis were scaled at a $1 / 4$ s sweep. If a reflection $\left(T_{R}\right)$ was marked by the stylus halfway down the vertical axis of the chart paper, a TWT of $1 / 8 \mathrm{~s}(125 \mathrm{~ms})$ would be recorded. A continuous acoustic profile is achieved by numerous sweeps of the stylus and advancement of the chart paper. The acoustic image that results appears as a geologic cross-section; however, this analogy is not correct. Ideally, to interpret the acoustic profile, the TWT is converted to depth. To do this a velocity $(C)$ of the acoustic wave in the medium must be determined or assumed. 


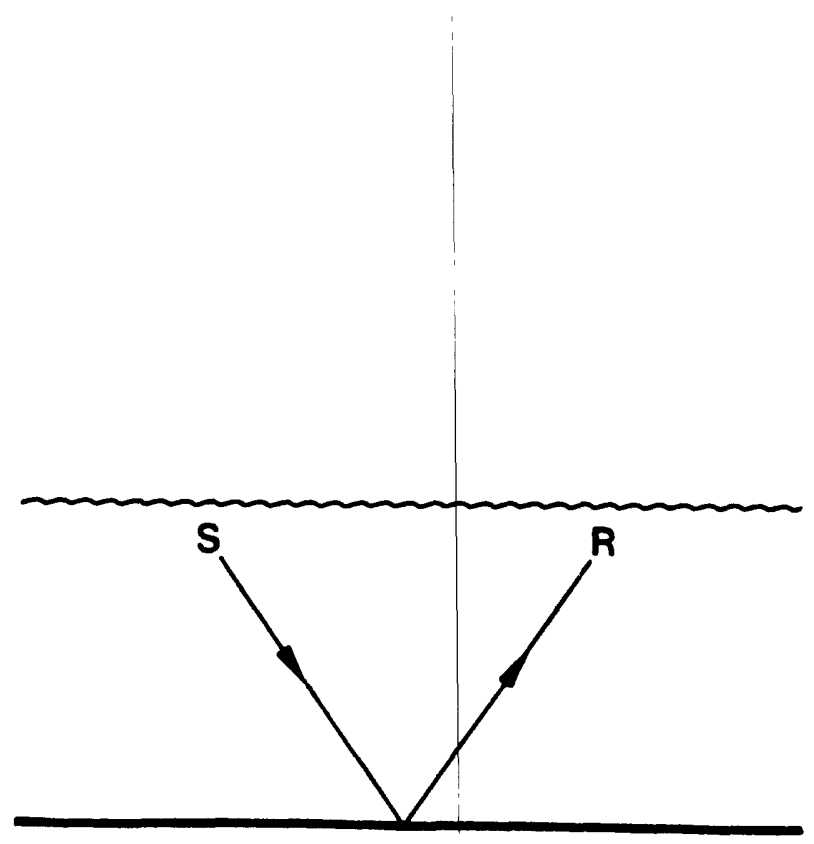

Figure 9-3. Ray path of two-way travel time (TWT) from source to receiver.

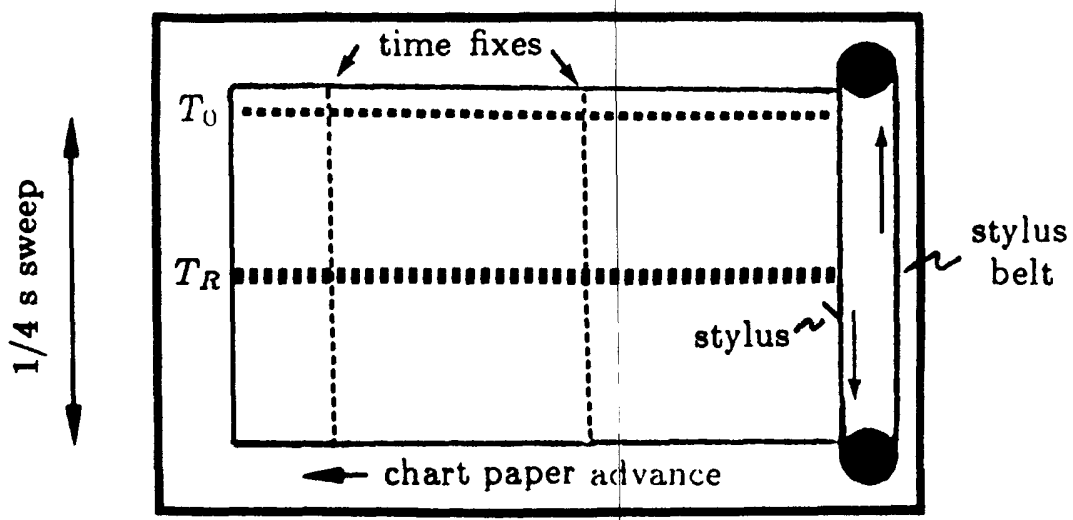

Figure 9-4. Graphic recorder showing vertical and horizontal scales on the chart paper, sweep rate, and example reflector. 
The degree to which the acoustic profile truly represents a geologic crosi-section depends on the accuracy of the velocity determinations. The following equation converts TWT to depth $(D)$

$$
D=\frac{C(T W T)}{2}
$$

For the example of the reflection $\left(T_{R}\right)$ (Figure $\left.9-4\right)$, the TWT of $1 / 8 \mathrm{~s}(125 \mathrm{~ms})$ is converted to a depth of $100 \mathrm{~m}$, assuming a velocity of $1600 \mathrm{~m} / \mathrm{s}$. Velocity assumptions and velocity determinations are a simplification of the velocity structure in sea water and sub-bottom sediments. Velocity heterogeneity in the sub-bottom is expected, thus caution is needed when interpreting an acoustic profile as a geologic cross-section. 


\section{APPENDIX 2. AVAILABILITY OF ACOUSTIC PROFILES}

A catalog available from the National Geophysical Data Center summarizes the marine geological and geophysical data available for the Beaufort Sea (National Geophysical Data Center, 1987), some of which was used in this study. The catalog and copies of the data may be obtained from the National Geophysical Data Center at the following address:

United States Department of Commerce

National Oceanic and Atmospheric Administration

National Environmental Satellite, Data, and Information Service

National Geophysical Data Center

325 Broadway, E/GC4, Dept. 426

Boulder, Colorado 80303-3328 USA 


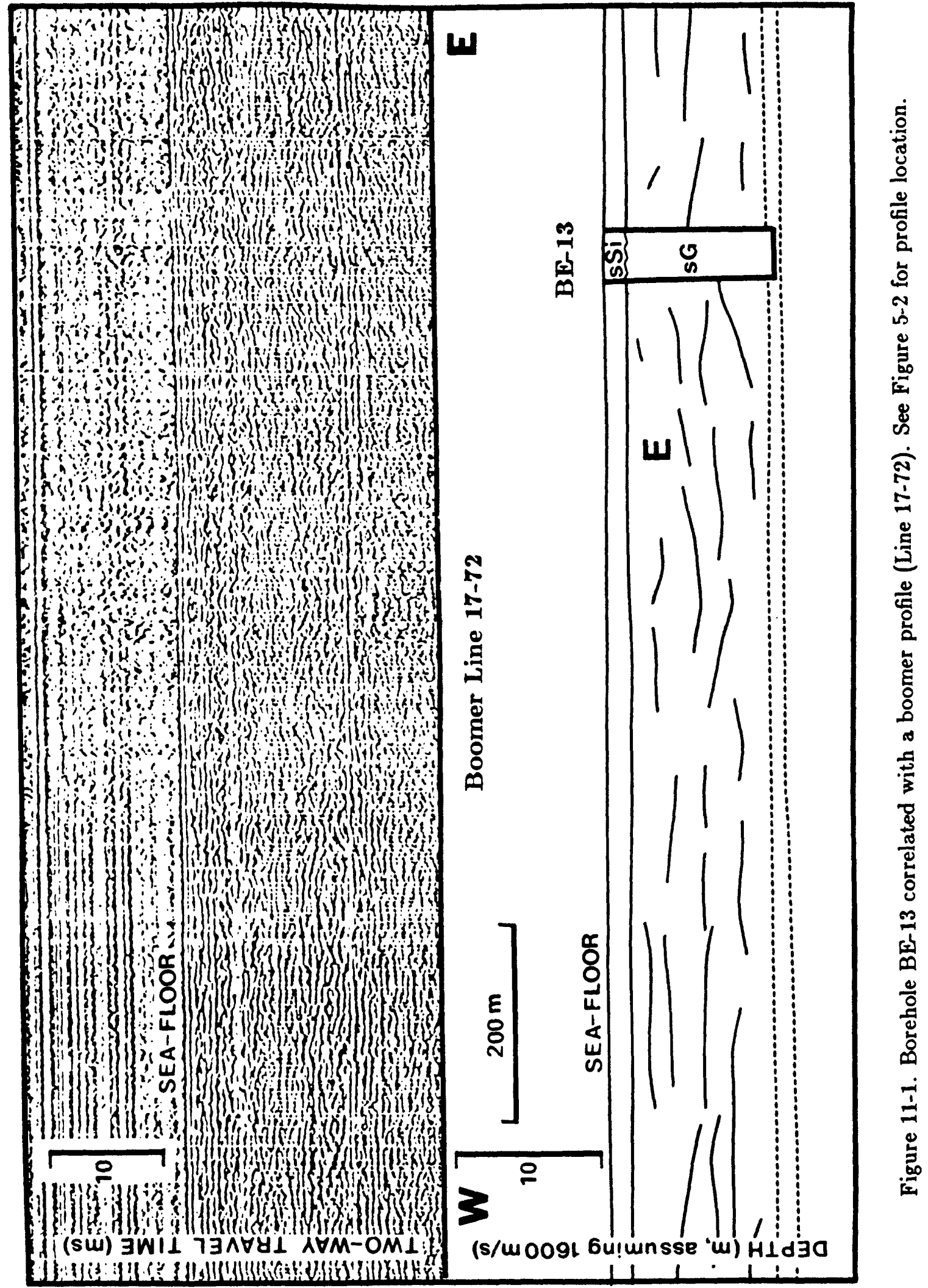




\section{APPENDIX 3. BOREHOLE CORRELATIONS}

The borehole and acoustic data were correlated by superimposing the borehole stratigraphy on the corresponding acoustic profile. An acoustic velocity of $1600 \mathrm{~m} / \mathrm{s}$ was used to convert two-way travel time (TWT) to depth in meters. Interpretive line drawings were illustrated for each acoustic profile.

Explanation of Symbols

Major Reflector

Reflector

Multiple

Lithologic Contact

G Gravel

S Sand

Si Sut

C Clay

M Mud

s G Sandy Gravel

Ice-bonded

E Partially-bonded 


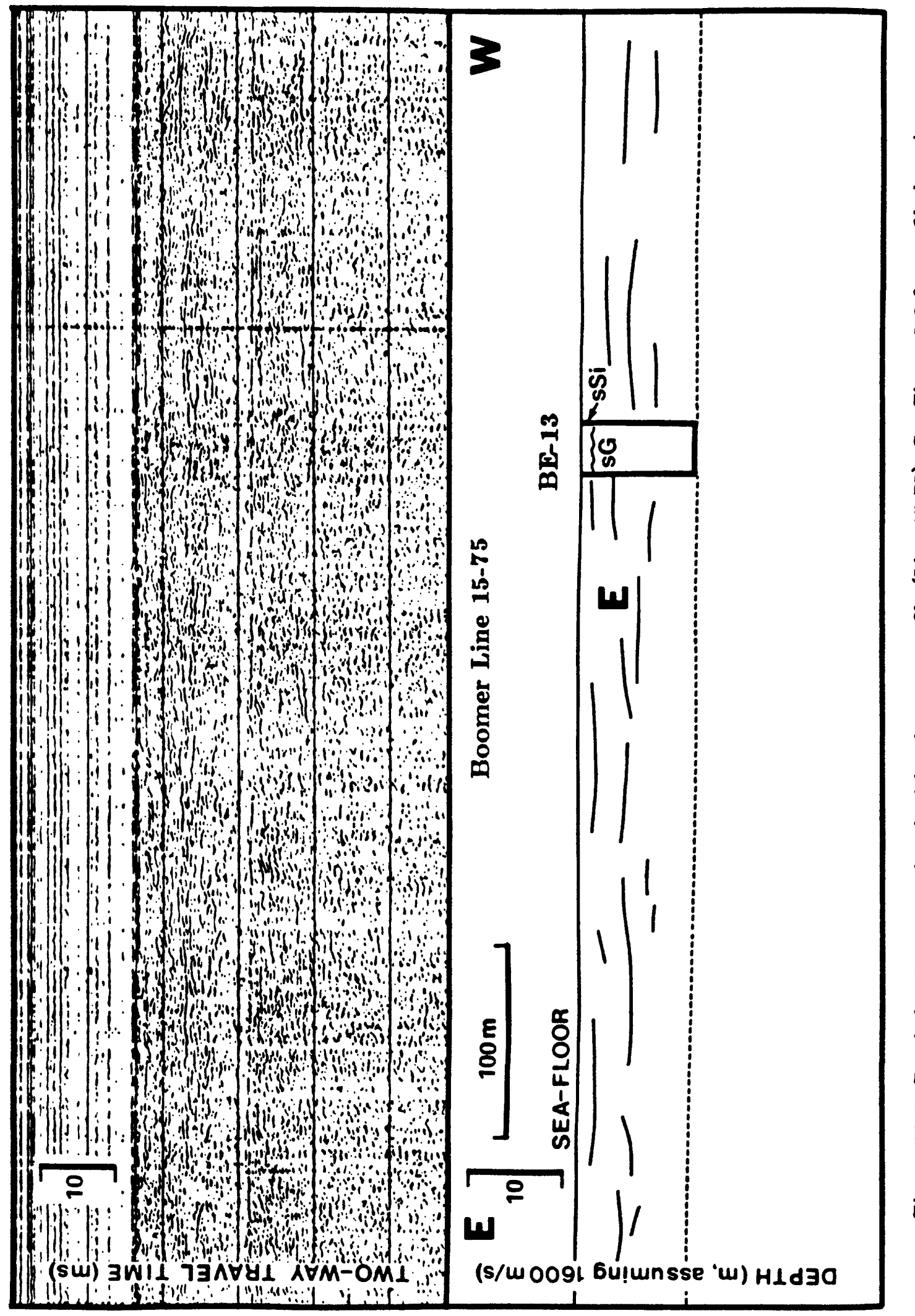

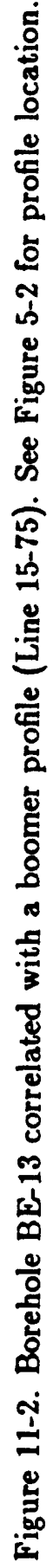




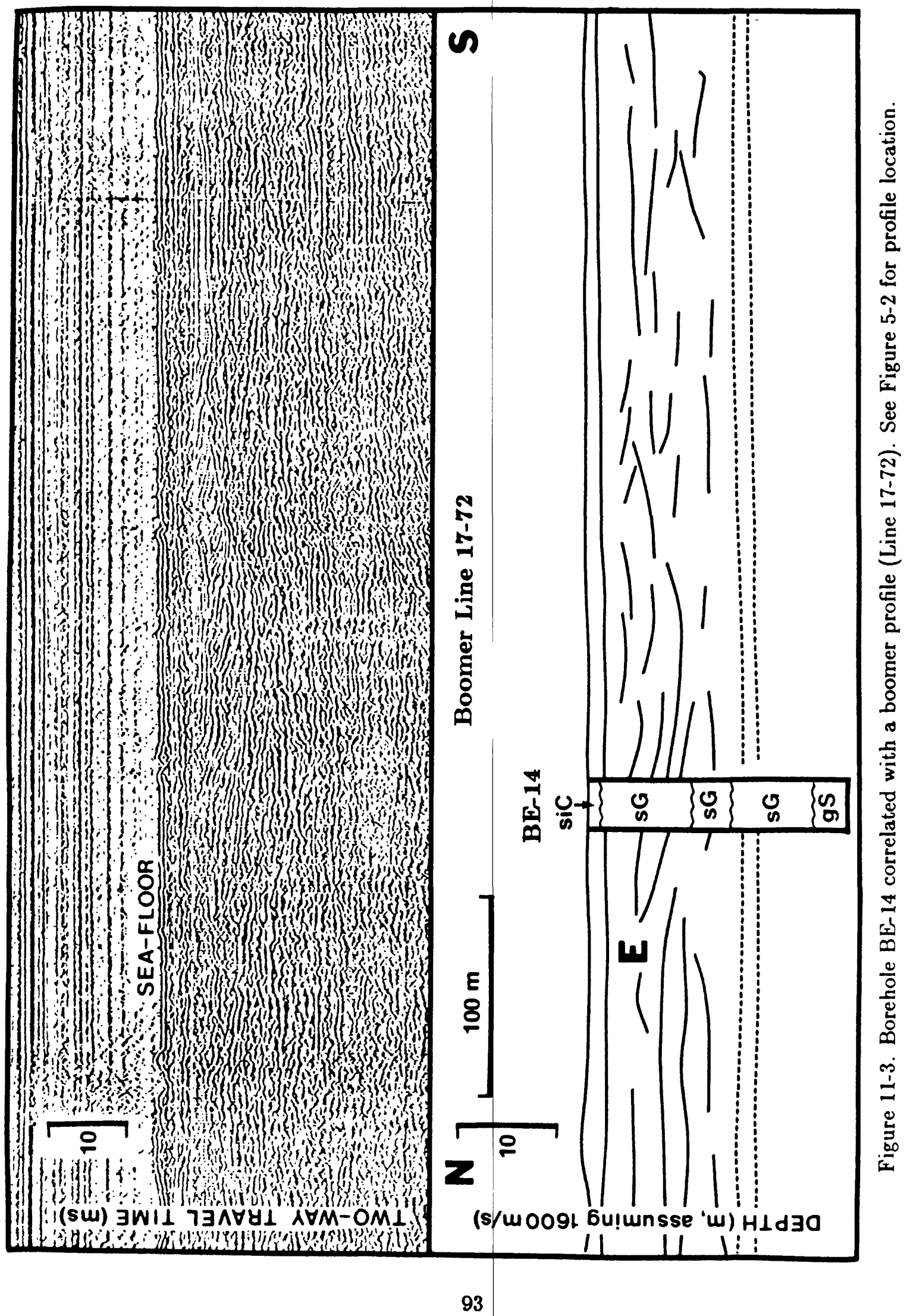




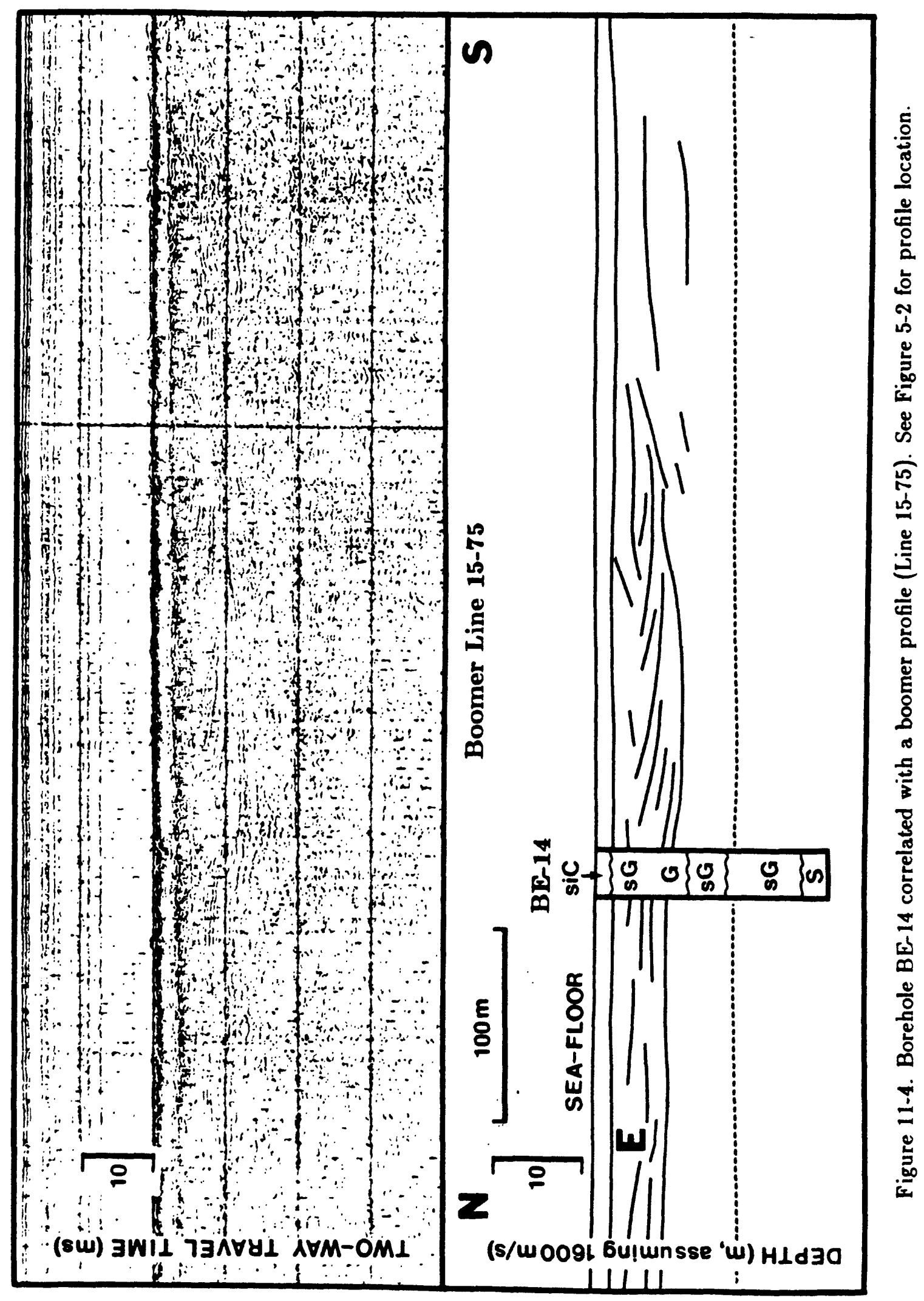




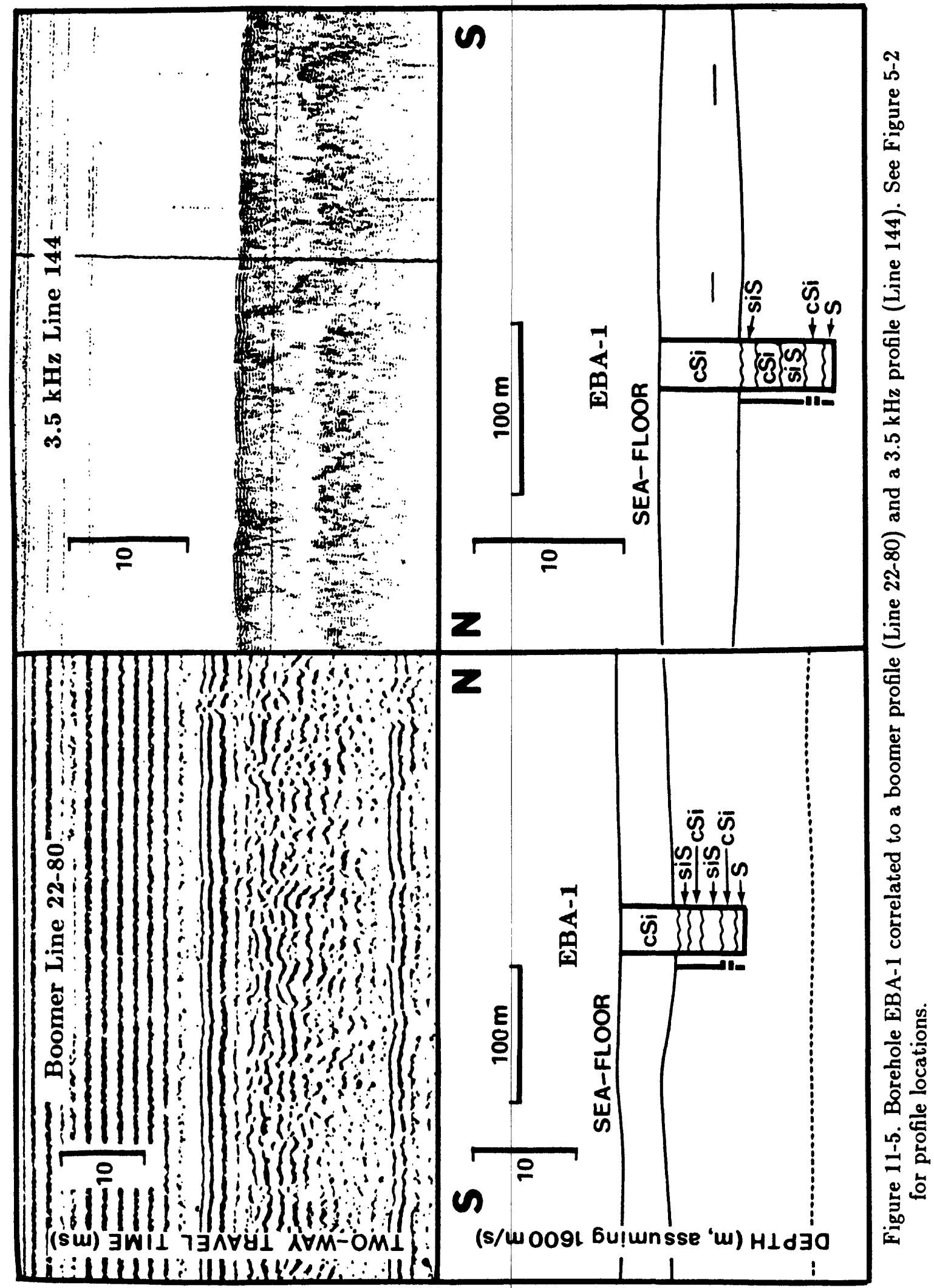




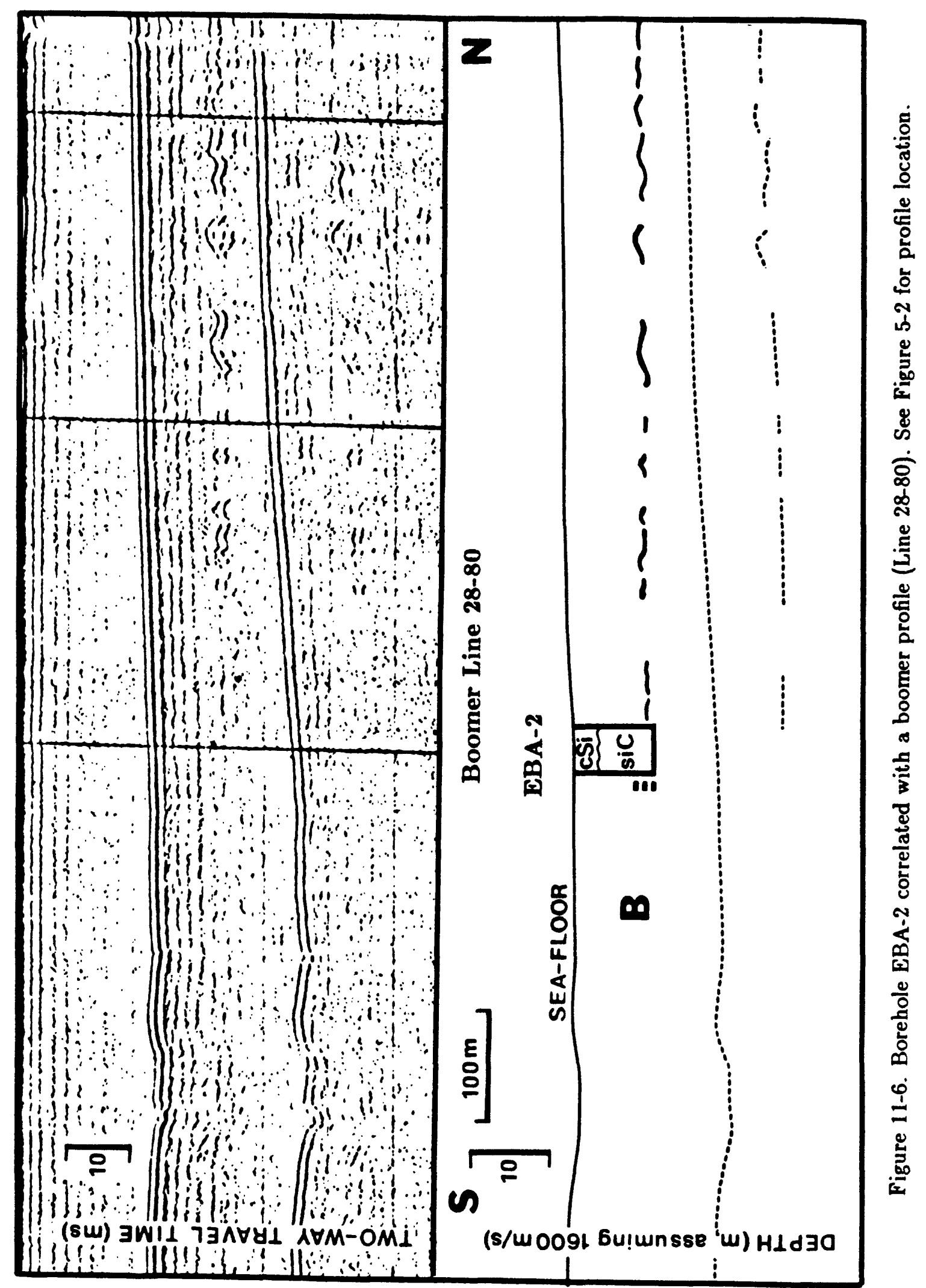




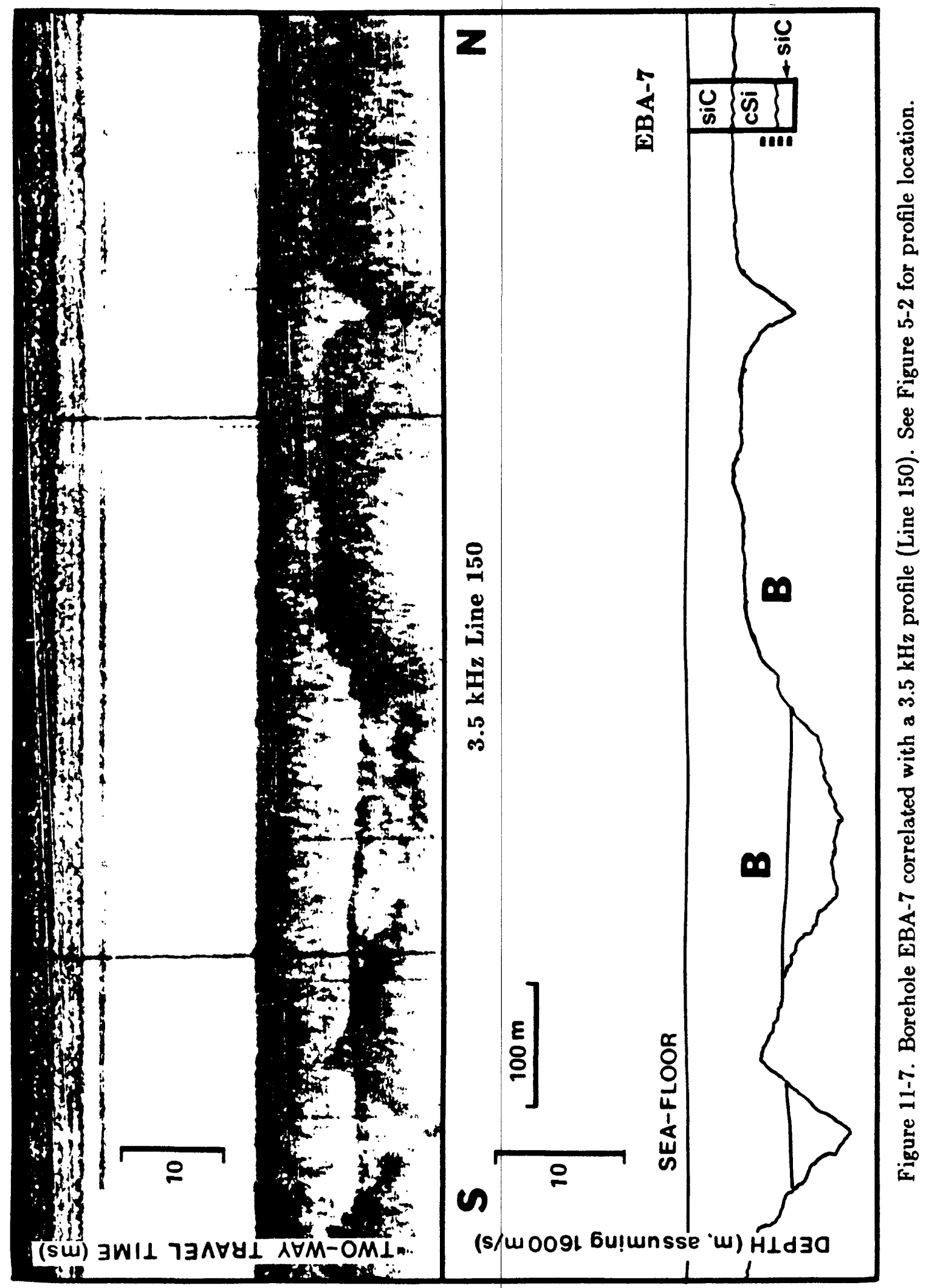




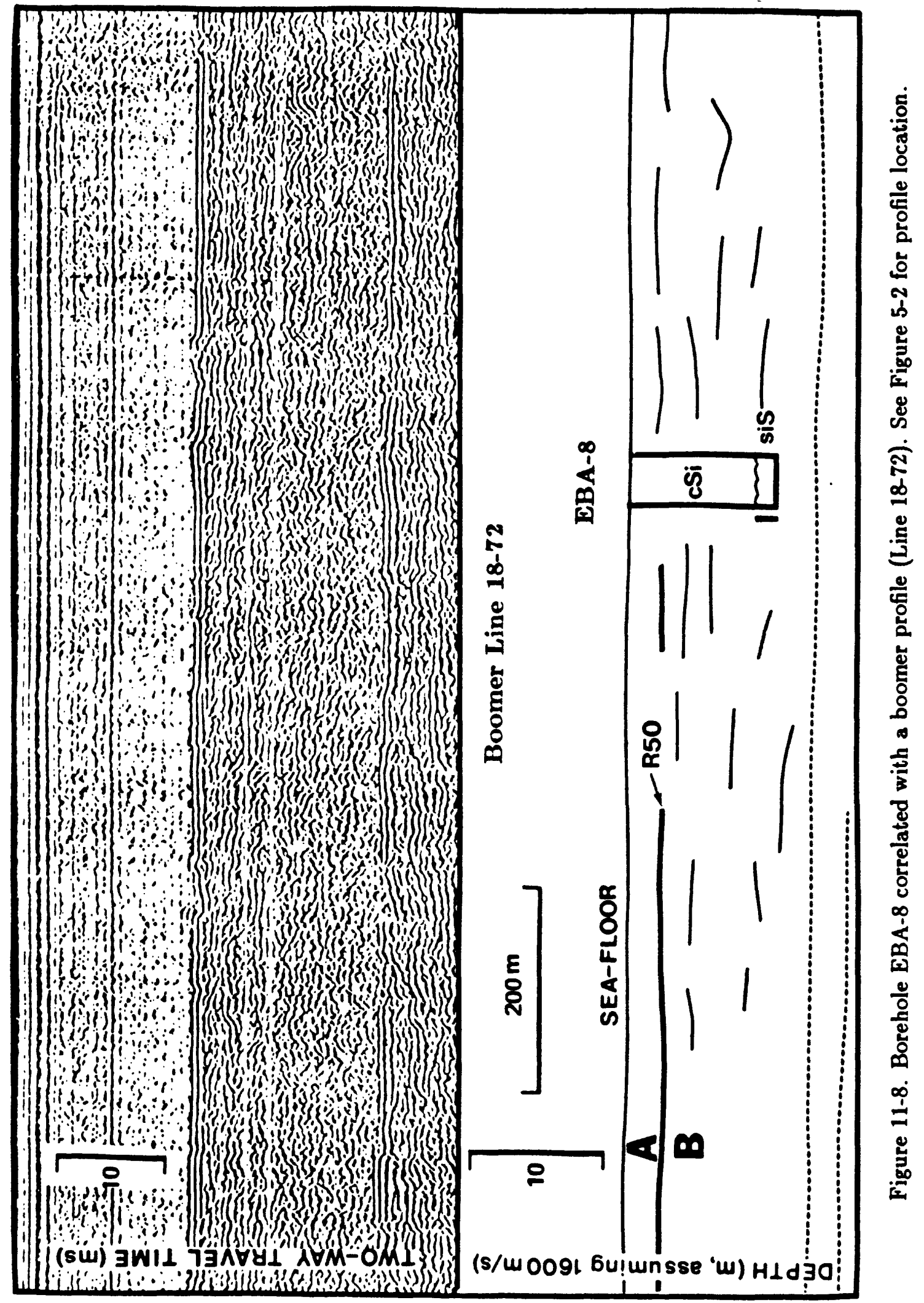




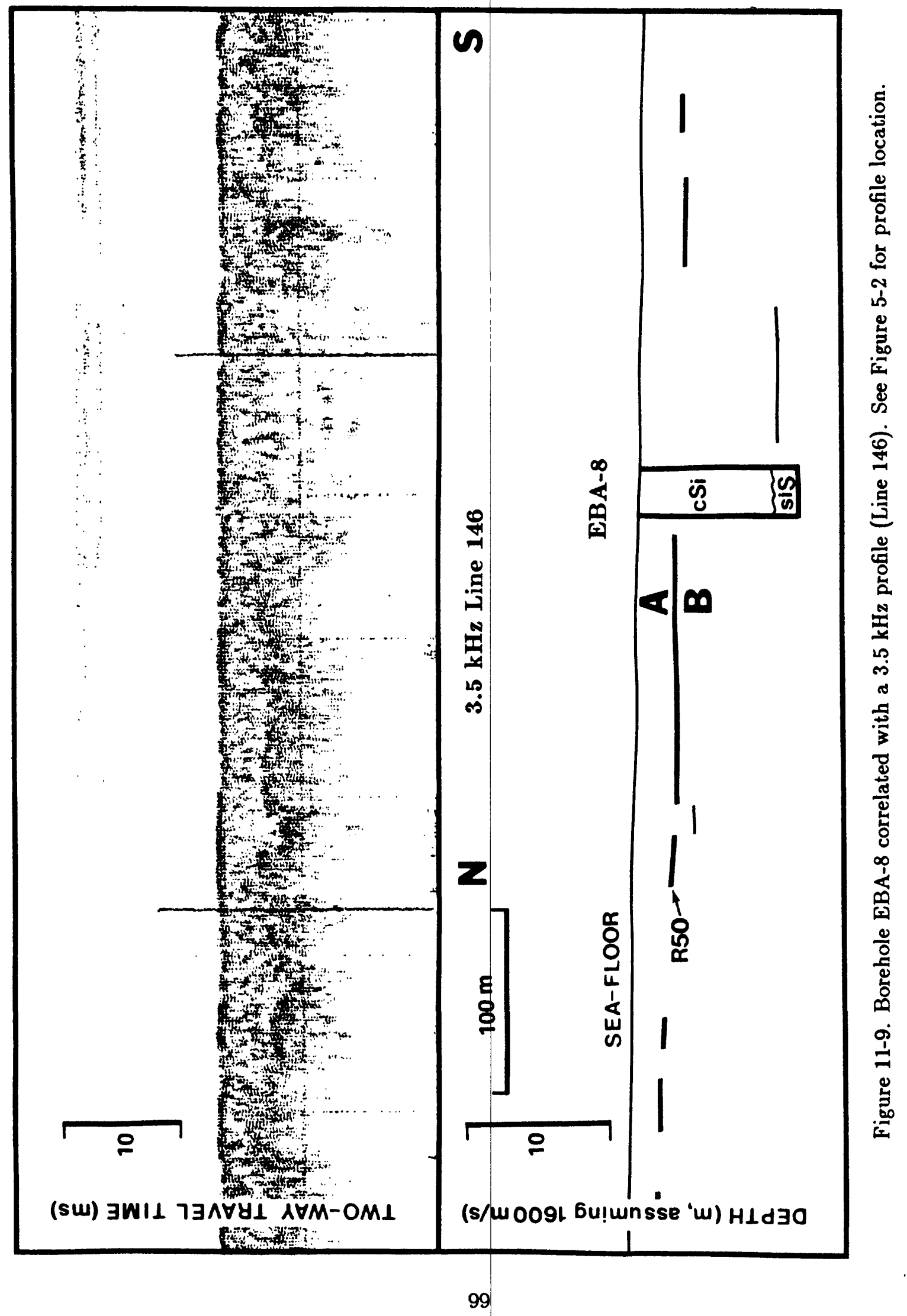




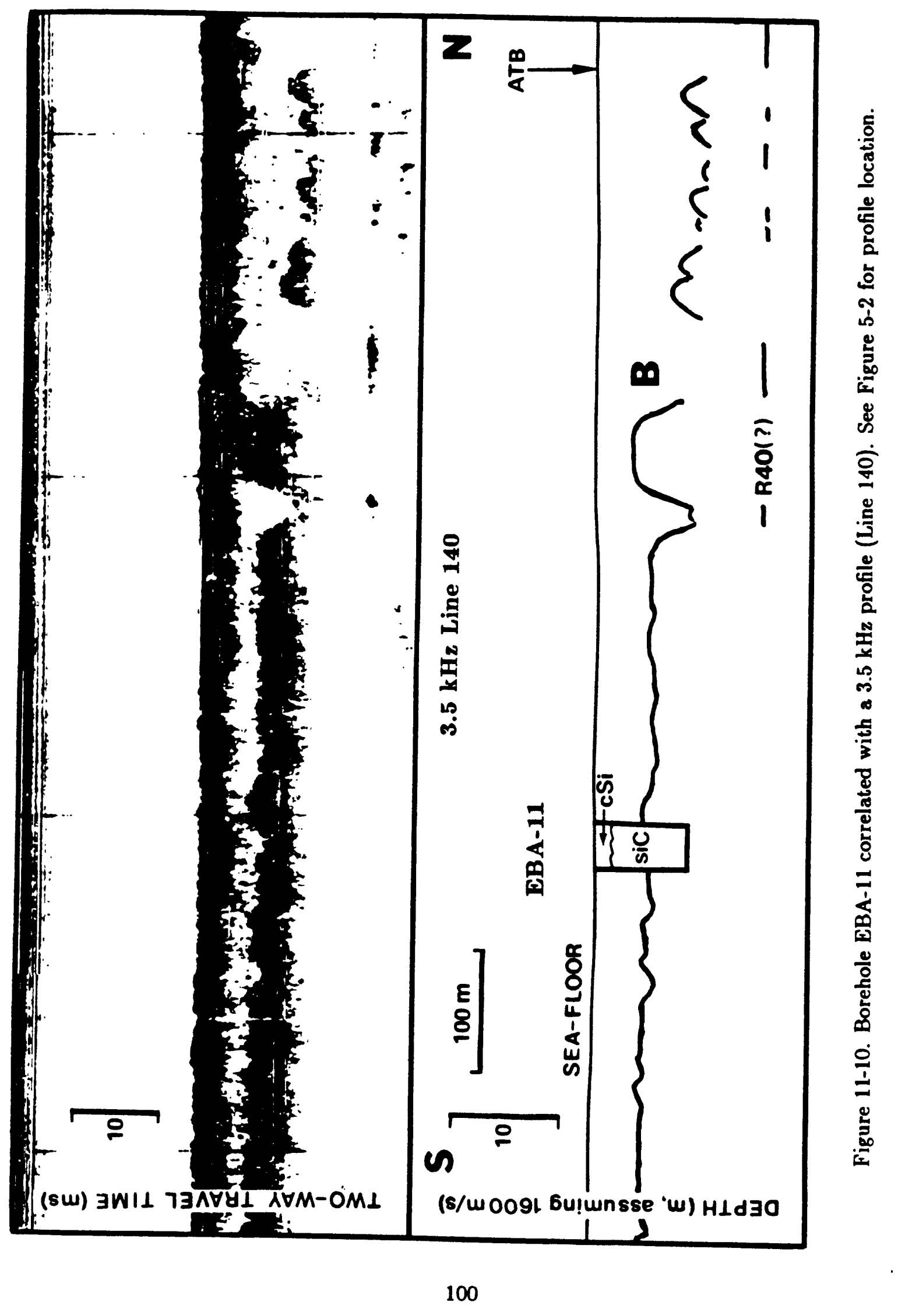




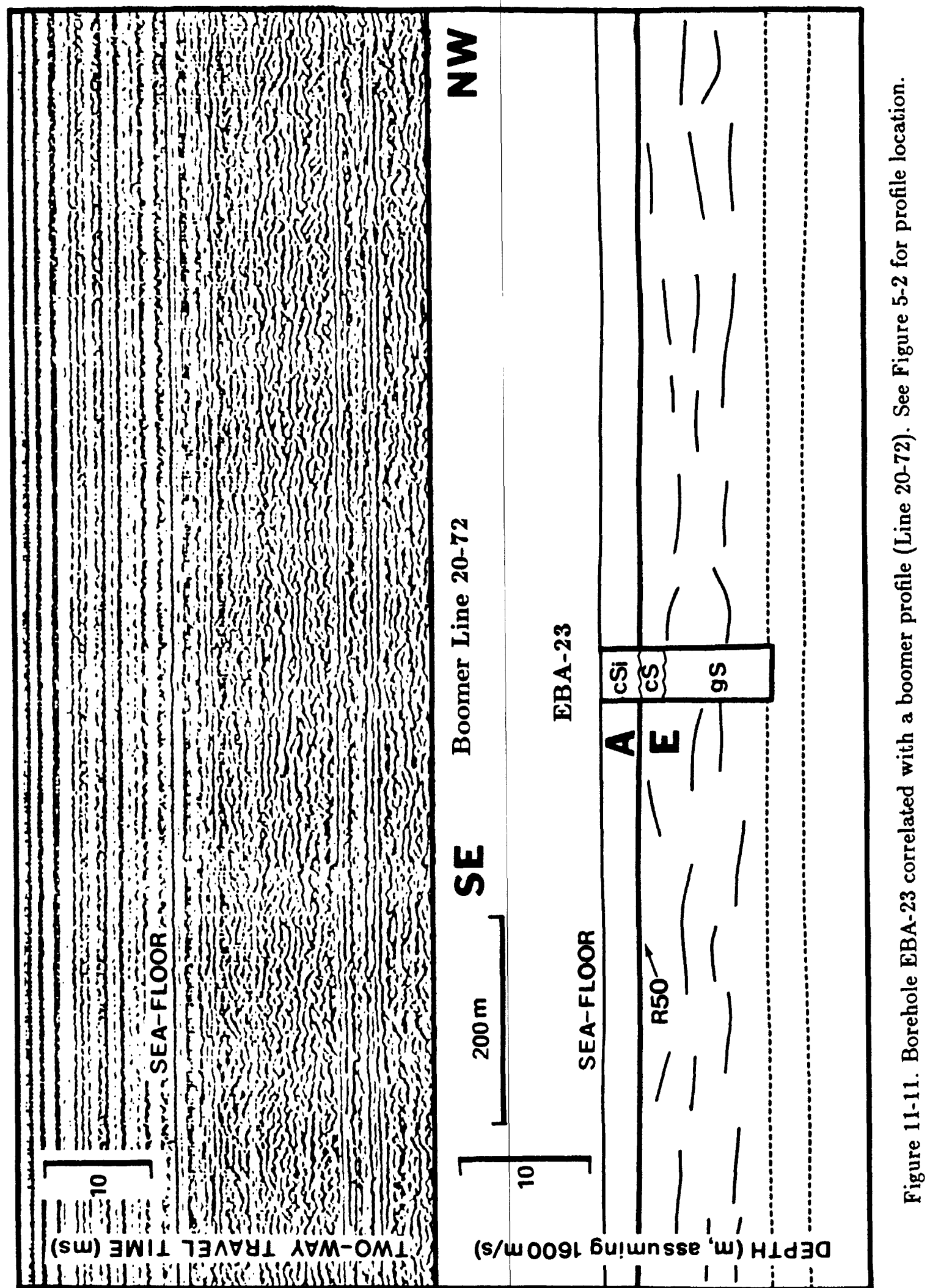




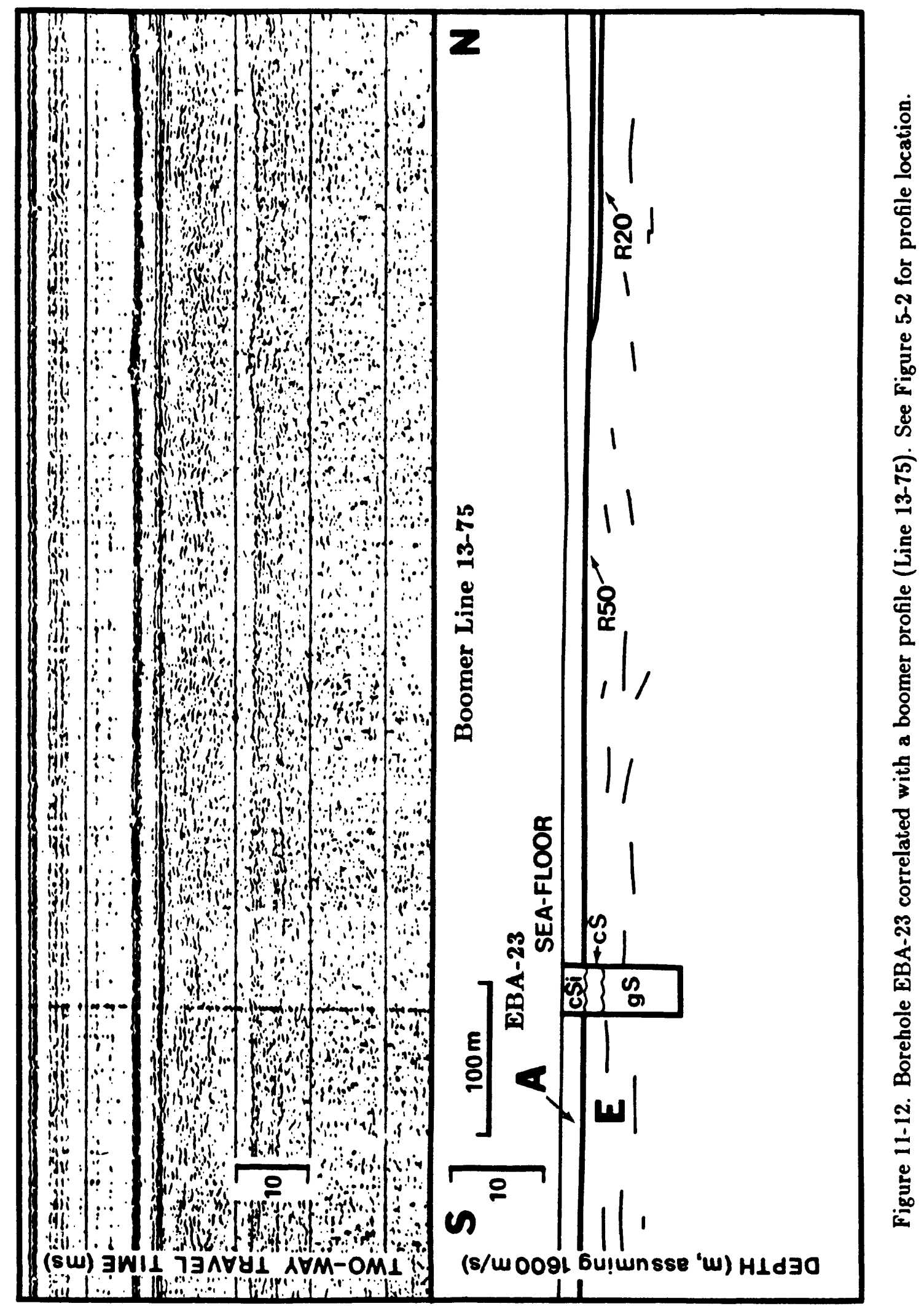




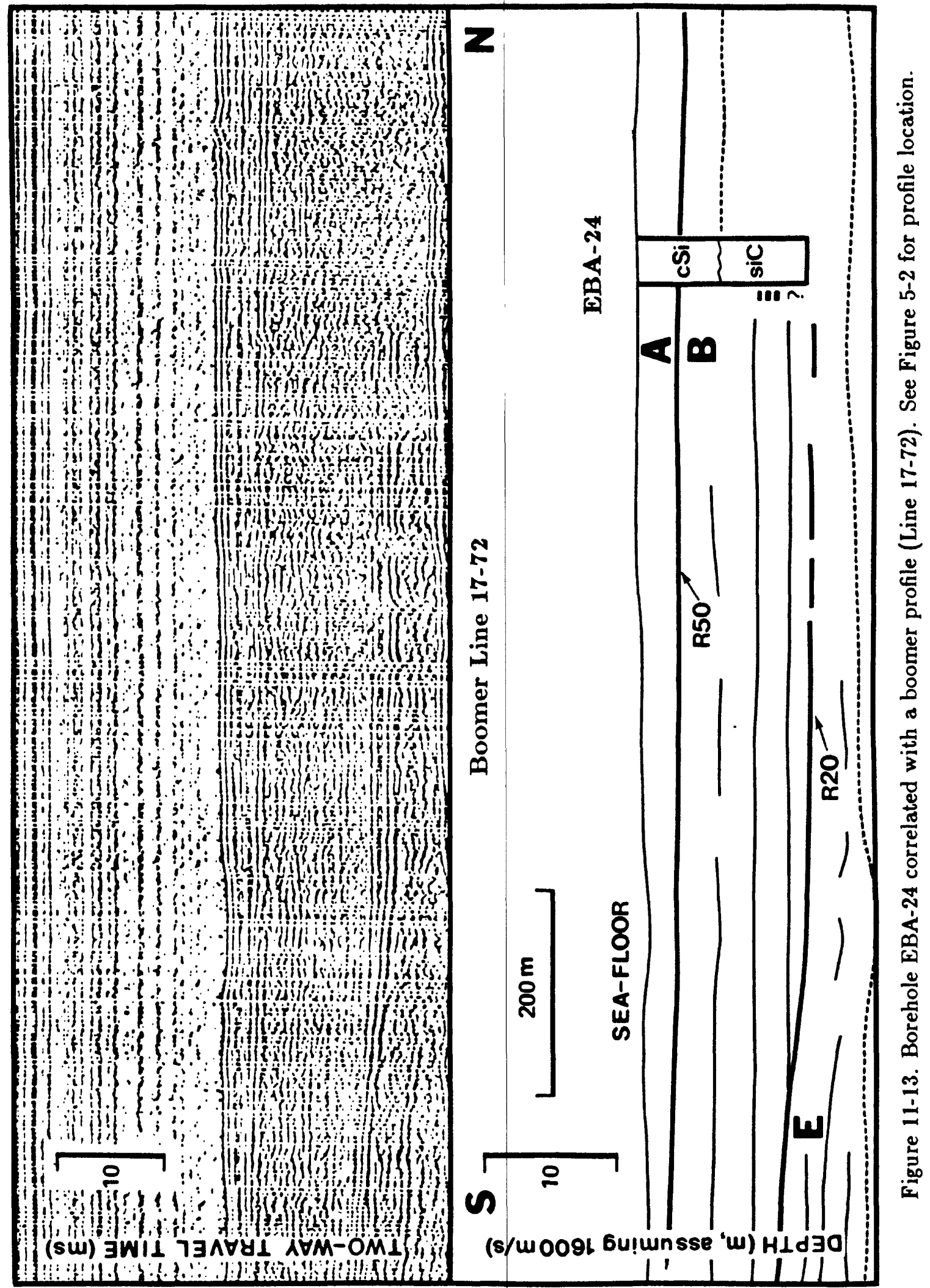




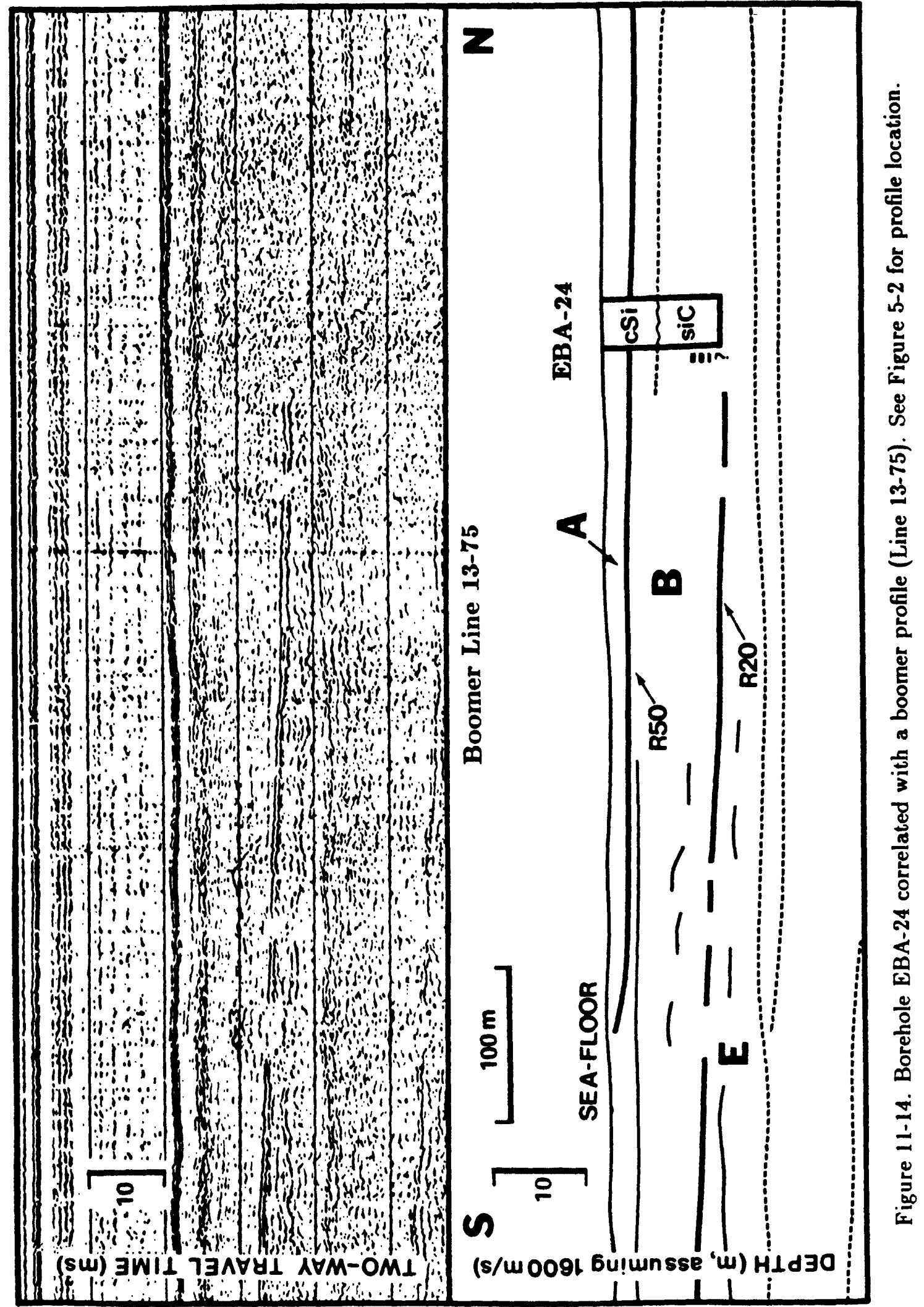




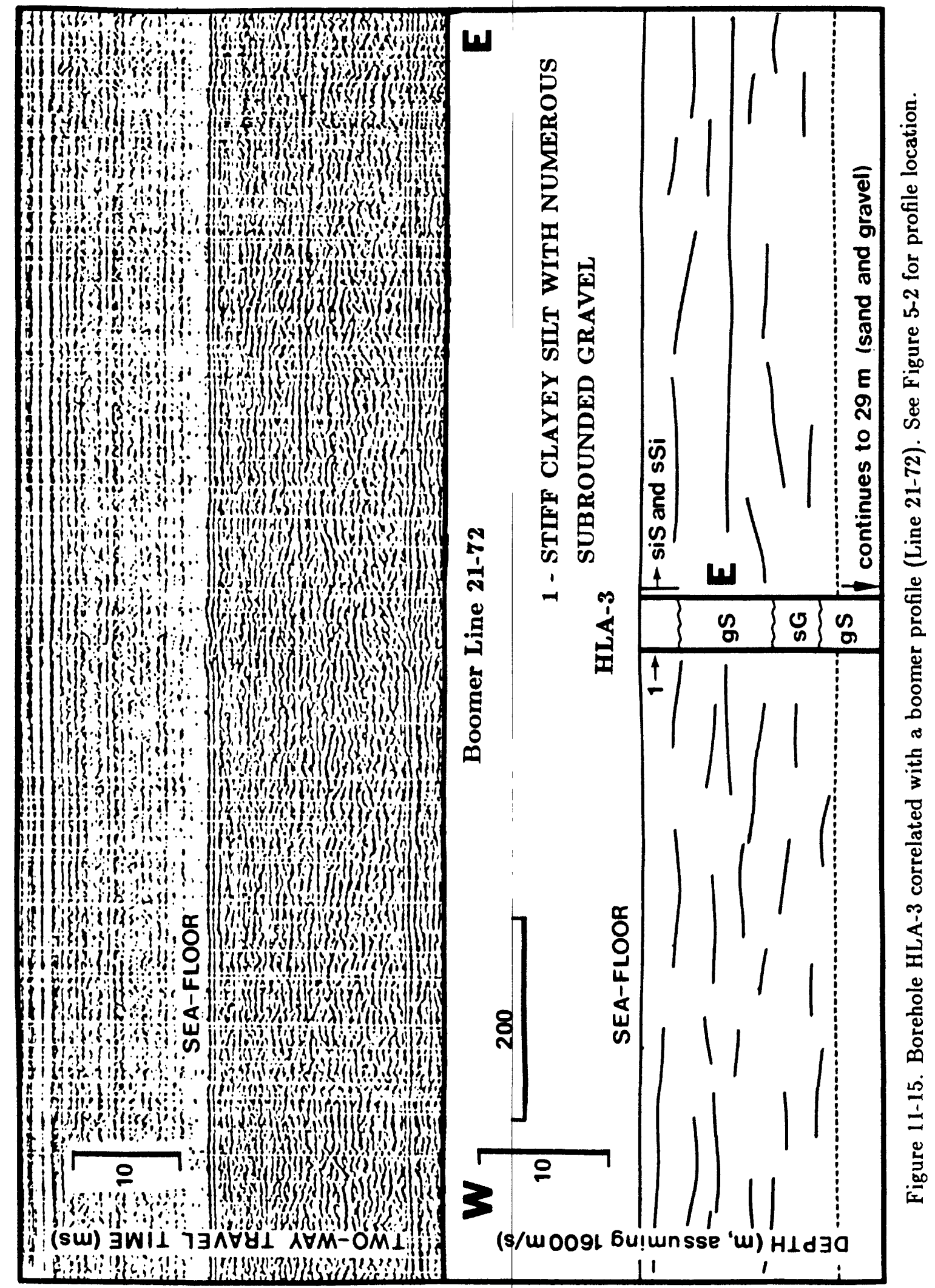




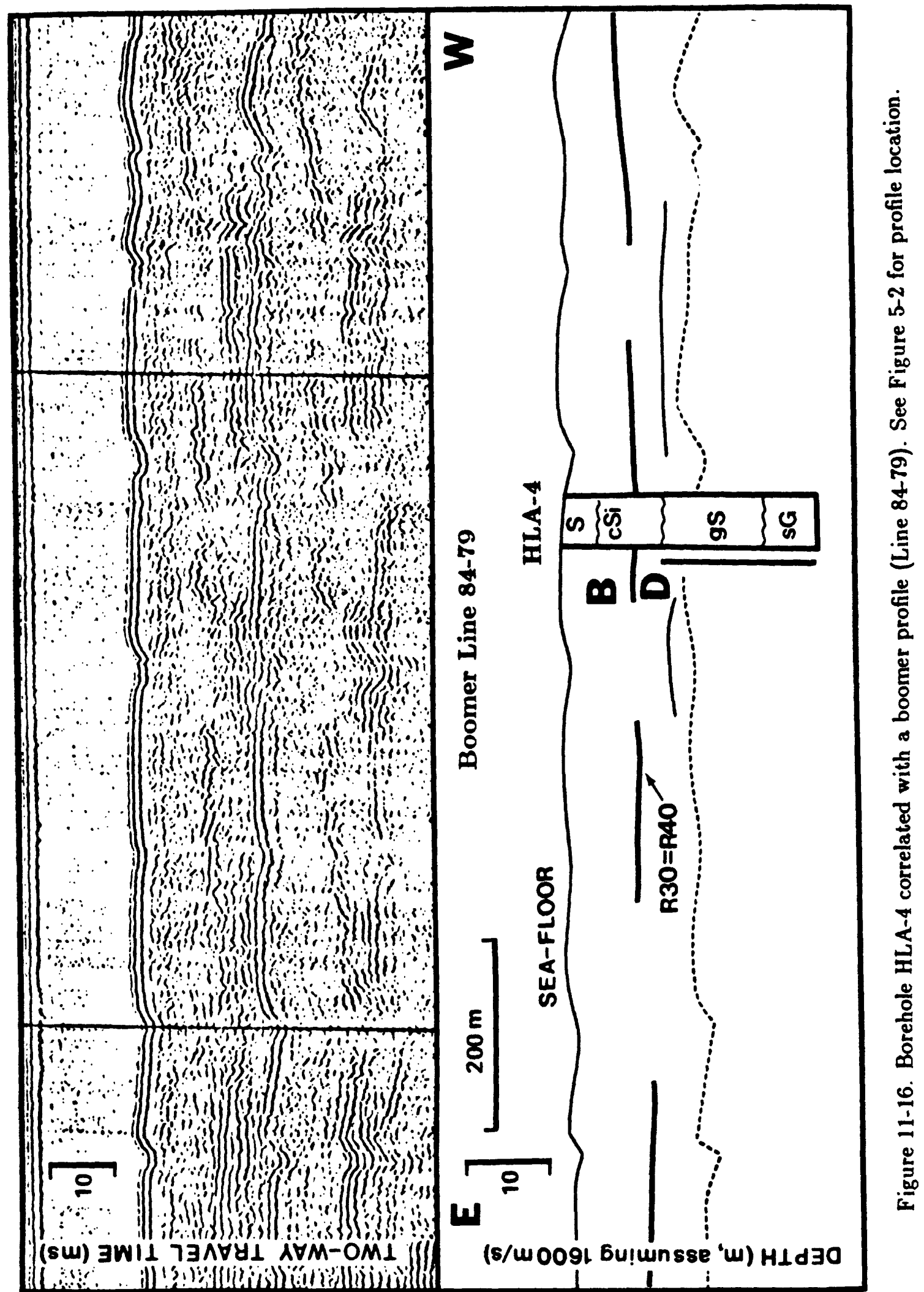




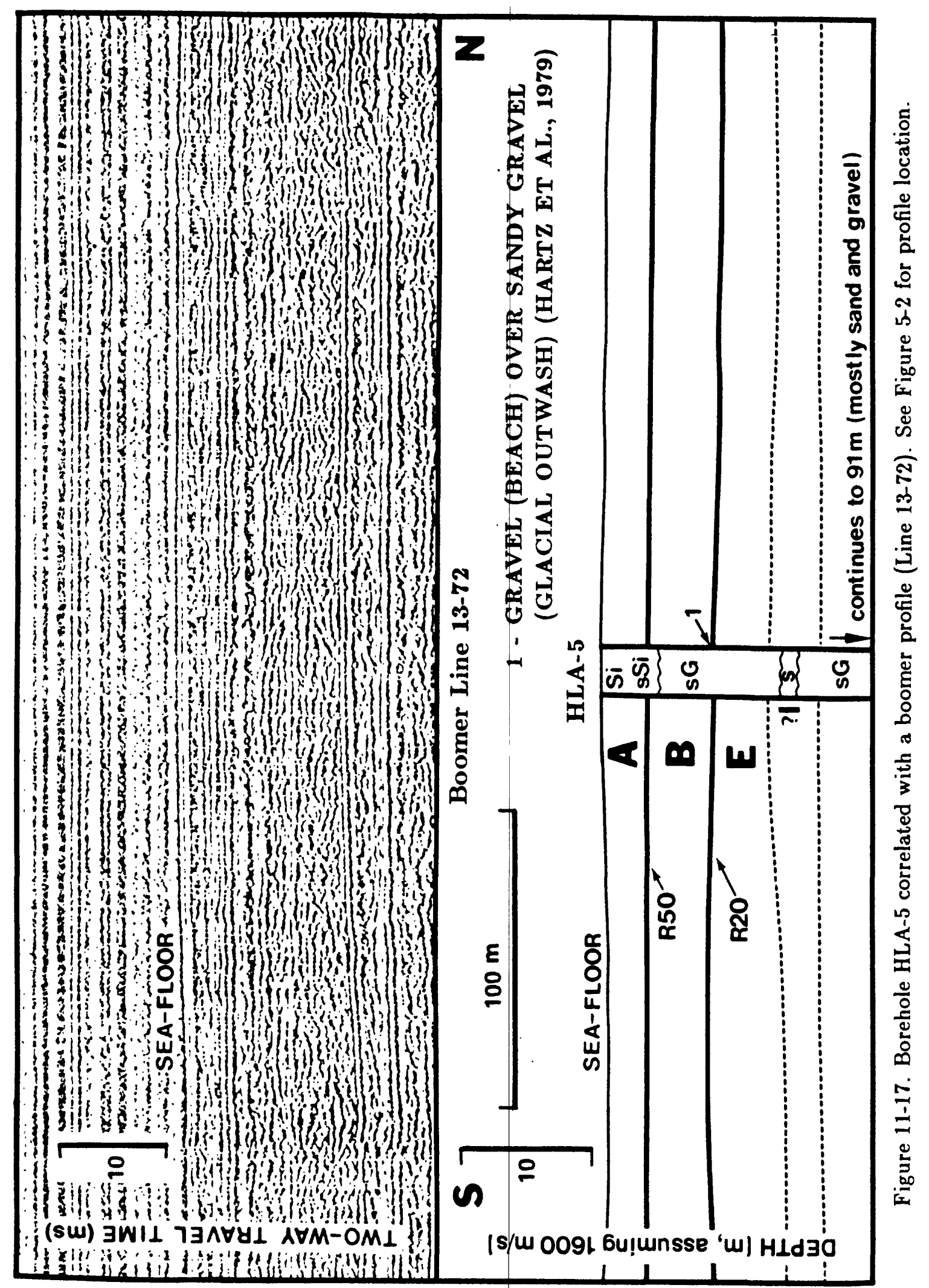




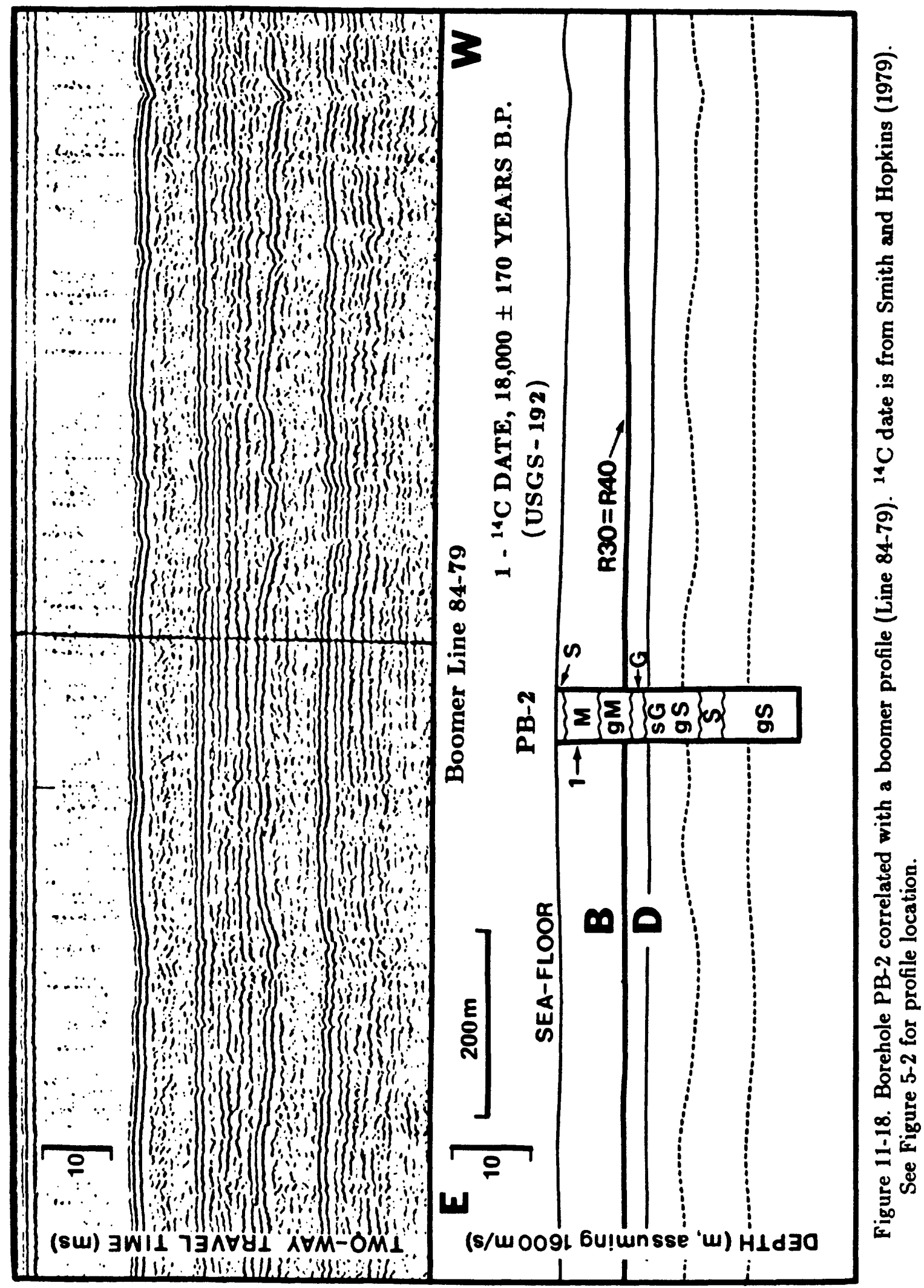

